Defense Threat Reduction Agency

8725 John J. Kingman Road, MS-6201

Fort Belvoir, VA 22060-6201

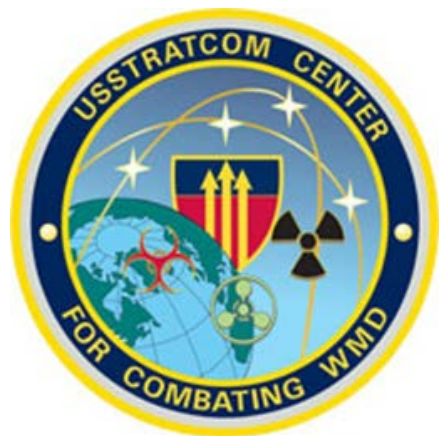

DTRA-TR-12-003 (R1)

\title{
Upper-Bound Radiation Dose Assessment for Military Personnel at McMurdo Station, Antarctica, between 1962 and 1979, Revision 1
}

DISTRIBUTION A. Approved for public release: distribution is unlimited.

July 2016

\section{Prepared by:}

McMurdo Station Radiation Dose Assessment Integrated Project Team

For:

Assistant Secretary of Defense for Health Affairs and Deputy Assistant Secretary of the Navy for Safety 
1. REPORT DATE $(D D-M M-Y Y Y Y)$ 29-07-2016

4. TITLE AND SUBTITLE

Upper-Bound Radiation Dose Assessment for Military Personnel at McMurdo Station, Antarctica, between 1962 and 1979, (Revision 1)
3. DATES COVERED (From - To)

\section{REPORT TYPE \\ Technical Report}

5a. CONTRACT NUMBER

5b. GRANT NUMBER

5c. PROGRAM ELEMENT NUMBER

\section{AUTHOR(S)}

Dunavant, Jason D. ${ }^{1}$, Chehata, Mondher ${ }^{1}$, Morris, William J. ${ }^{2}$, Fairchild Gregory J. ${ }^{3}$, Blake, Paul K. ${ }^{4}$.

5e. TASK NUMBER

5f. WORK UNIT NUMBER

7. PERFORMING ORGANIZATION NAME(S) AND ADDRESS(ES)

1. Leidos, 11951 Freedom Drive, Reston, VA 20190

2. McMurdo Station Crew Member (Veteran)

3. Naval Dosimetry Center, Bethesda, MD

4. Defense Threat Reduction Agency, Fort Belvoir VA

9. SPONSORING/MONITORING AGENCY NAME(S) AND ADDRESS(ES)

Nuclear Technologies Department, Attn: Dr. Paul Blake

Defense Threat Reduction Agency

8725 John J. Kingman Road, Mail Stop 6201

Fort Belvoir, VA 22060-6201

12. DISTRIBUTION AVAILABILITY STATEMENT

DISTRIBUTION A. Approved for public release: distribution is unlimited.

\section{SUPPLEMENTARY NOTES}

\section{ABSTRACT}

U.S. veterans who were assigned at McMurdo Station, Antarctica, from 1962 to1979, have expressed concern that their health may have been affected by radiological releases from an onsite nuclear power plant. This report presents the results of the Department of Defense's radiation dose assessment for McMurdo Station veterans who were not monitored for occupational radiation exposure. This assessment determined that the radiation doses were low and the associated probability that disease could have arisen from these doses is also low. Finally, recommendations are provided for McMurdo Station veterans, their dependents, the Department of Veterans Affairs (VA), and the Naval Dosimetry Center regarding the VA radiogenic disease claims process.

\section{SUBJECT TERMS}

McMurdo Station, Veterans, Radiation Dose Assessment, Nuclear Test Personnel Review Program

\begin{tabular}{|c|c|c|c|c|}
\hline \multicolumn{3}{|c|}{ 16. SECURITY CLASSIFICATION OF: } & \multirow{2}{*}{$\begin{array}{l}\text { 17. LIMITATION OF } \\
\text { ABSTRACT } \\
\qquad\end{array}$} & \multirow{2}{*}{$\begin{array}{l}\text { 18. NUMBER } \\
\text { OF PAGES } \\
129 \text { Pages }\end{array}$} \\
\hline a. REPORT & b. ABSTRACT & c. THIS PAGE & & \\
\hline u & u & U & & \\
\hline
\end{tabular}

19a. NAME OF RESPONSIBLE PERSON

Paul K. Blake, PhD

19b. TELEPONE NUMBER (Include area code)

(703) $767-3384$ 
UNIT CONVERSION TABLE

U.S. customary units to and from international units of measurement ${ }^{*}$

\begin{tabular}{|c|c|c|c|}
\hline U.S. Customary Units & Multipl & & International Units \\
\hline $\begin{array}{l}\text { Length/Area/Volume } \\
\text { inch (in) } \\
\text { foot (ft) } \\
\text { yard (yd) } \\
\text { mile (mi, international) } \\
\text { mile (nmi, nautical, U.S.) } \\
\text { barn (b) } \\
\text { gallon (gal, U.S. liquid) } \\
\text { cubic foot (ft' } \\
\text { Mass/Density } \\
\text { pound (lb) } \\
\text { atomic mass unit (AMU) } \\
\text { pound-mass per cubic foot (lb ft }{ }^{-3} \text { ) } \\
\text { Pound-force (lbf avoirdupois) } \\
\text { Energy/Work/Power } \\
\text { electronvolt (eV) } \\
\text { erg } \\
\text { kiloton (kT) (TNT equivalent) } \\
\text { British thermal unit (Btu) (thermochemical) } \\
\text { foot-pound-force (ft lbf) } \\
\text { calorie (cal) (thermochemical) } \\
\text { Pressure } \\
\text { atmosphere (atm) } \\
\text { pound force per square inch (psi) } \\
\text { Temperature } \\
\text { degree Fahrenheit ( }{ }^{\circ} \mathrm{F} \text { ) } \\
\text { degree Fahrenheit ( }{ }^{\circ} \mathrm{F} \text { ) } \\
\text { Radiation } \\
\text { activity of radionuclides [curie (Ci)] } \\
\text { air exposure [roentgen (R)] } \\
\text { absorbed dose (rad) } \\
\text { equivalent and effective dose (rem) }\end{array}$ & $\begin{array}{l}2.54 \\
3.048 \\
9.144 \\
1.609344 \\
1.852 \\
1 \\
3.785412 \\
2.831685 \\
\\
4.535924 \\
1.660539 \\
1.601846 \\
4.448222 \\
1.602177 \\
1 \\
4.184 \\
1.054350 \\
1.355818 \\
4.184 \\
\\
1.013250 \\
6.984757 \\
\\
{\left[\mathrm{~T}\left({ }^{\circ} \mathrm{F}\right)-3\right.} \\
{\left[\mathrm{T}\left({ }^{\circ} \mathrm{F}\right)+4\right.} \\
\\
3.7 \\
2.579760 \\
1 \\
1\end{array}$ & $\begin{array}{l}\times 10^{-1} \\
\times 10^{-27} \\
\times 10^{1} \\
\times 10^{-19} \\
\times 10^{-7} \\
\times 10^{12} \\
\times 10^{3} \\
\\
\times 10^{5} \\
\times 10^{3} \\
8 \\
7] / 1.8 \\
\times 10^{10} \\
\times 10^{-4} \\
\times 10^{-2} \\
\times 10^{-2}\end{array}$ & $\begin{array}{l}\text { meter }(\mathrm{m}) \\
\text { meter }(\mathrm{m}) \\
\text { meter }(\mathrm{m}) \\
\text { meter }(\mathrm{m}) \\
\text { meter }(\mathrm{m}) \\
\text { square meter }\left(\mathrm{m}^{2}\right) \\
\text { cubic meter }\left(\mathrm{m}^{3}\right) \\
\text { cubic meter }\left(\mathrm{m}^{3}\right) \\
\text { kilogram }(\mathrm{kg}) \\
\text { kilogram }(\mathrm{kg}) \\
\text { kilogram per cubic meter }\left(\mathrm{kg} \mathrm{m}^{-3}\right) \\
\text { Newton }(\mathrm{N}) \\
\text { joule }(\mathrm{J}) \\
\text { joule }(\mathrm{J}) \\
\text { joule }(\mathrm{J}) \\
\text { joule }(\mathrm{J}) \\
\text { joule }(\mathrm{J}) \\
\text { joule }(\mathrm{J}) \\
\text { pascal }(\mathrm{Pa}) \\
\text { pascal }(\mathrm{Pa}) \\
\text { degree Celsius }\left({ }^{\circ} \mathrm{C}\right) \\
\text { kelvin }(\mathrm{K}) \\
\text { per second }\left(\mathrm{s}^{-1+}\right) \\
\text { coulomb per kilogram }\left(\mathrm{C} \mathrm{kg}{ }^{-1}\right) \\
\text { joule per kilogram }\left(\mathrm{J} \mathrm{kg}^{-18}\right) \\
\text { joule per kilogram }\left(\mathrm{J} \mathrm{kg}^{-1 * *}\right)\end{array}$ \\
\hline
\end{tabular}

"Specific details regarding the implementation of SI units may be viewed at http://www.bipm.org/en/si/.

${ }^{\dagger}$ Multiply the U.S. customary unit by the factor to get the international unit. Divide the international unit by the factor to get the U.S. customary unit.

${ }^{\ddagger}$ The special name for the SI unit of the activity of a radionuclide is the becquerel (Bq). (1 Bq $\left.=1 \mathrm{~s}^{-1}\right)$.

${ }^{\S}$ The special name for the SI unit of absorbed dose is the gray (Gy). (1 Gy $\left.=1 \mathrm{~J} \mathrm{~kg}^{-1}\right)$.

${ }^{* *}$ The special name for the SI unit of equivalent and effective dose is the sievert (Sv). (1 Sv $\left.=1 \mathrm{~J} \mathrm{~kg}^{-1}\right)$. 


\section{Revision Notes}

This revision corrects minor errors in the original technical report, DTRA-TR-12-003, dated June 1, 2013. These include corrections of some dosimetry statistics in Table 5, and corrections to some of the dose values expressed in SI units in Table 30. In addition, selected text in Tables 11 and 12 was revised to be consistent with the purpose of those tables, and the text in Section 5.1.1 was rearranged so that table citations are in the correct sequence. Finally, minor editorial revisions were made in various discussions. None of these revisions affect the doses used by the Naval Dosimetry Center in its performance of dose assessments for claims filed with the Department of Veterans Affairs by McMurdo Station Support personnel. 


\title{
Acknowledgments
}

This work has been conducted through the cooperation of McMurdo Station veterans, the U.S. Navy, the U.S. Army, the Department of Veterans Affairs (VA), the Veterans' Advisory Board on Dose Reconstruction (VBDR), and the Defense Threat Reduction Agency (DTRA)'s Nuclear Test Personnel Review (NTPR) Integrated Project Team (IPT).

\section{McMurdo Station Veterans}

Charles Fegley

James M. Kelly

Arthur C. Tate

Bill Westerfield

\section{U.S. Navy}

CDR Gregory R. Kahles, USN, Radiological Affairs Support Office

Gina Nichols, Archivist, U.S. Navy Seabee Museum

CDR James Cassata, USN, Uniformed Services University of Health Sciences

\author{
U.S. Army \\ Brian Hearty, U.S. Army Corps of Engineers \\ Phil Shubert, Army Reactor Office
}

VA

Bradley Flohr, Jacqueline Imboden, and Jerry Steele; Veterans Benefits Administration

Paul Ciminera and Daniel McClung; Veterans Health Administration

\section{VBDR}

Harold L. Beck

Paul G. Voillequé

Gary H. Zeman

DTRA NTPR IPT

LCDR Gerald Burke, USN, DTRA

Brian Malik, L-3 Stratis

Michael McKenzie-Carter, SAIC

Stephen D. Egbert, SAIC 


\section{Executive Summary}

U.S. veterans who were assigned at McMurdo Station, Antarctica, from 1962 to 1979, have expressed concern that their health may have been affected by radiological releases from an onsite nuclear power plant (NPP). In response to this concern, the Under Secretary of Defense for Personnel and Readiness stated that the Department of Defense (DoD) would work with the Department of Veterans Affairs (VA) and the Veterans' Advisory Board on Dose Reconstruction (VBDR) to assess these risks. A DoD integrated program team was formed of military, civilian, and contract radiation health experts from the Defense Threat Reduction Agency, the Naval Dosimetry Center, and McMurdo Station veteran volunteers. This team calculated veteran radiation doses and assessed the probability that these radiation doses may have caused subsequent disease. During this assessment process, VA and VBDR subject matter experts provided critical peer-review.

The McMurdo Station NPP was designed to generate electricity and distill drinking water in Antarctica thus reducing the significant challenge of transporting and storing fuel oil at this remote location. It was assembled at McMurdo Station in 1962 and operated through 1972. It was placed in standby mode in October 1972 when shield water leakage into the insulation around the pressure vessel and primary coolant piping created the possibility of chloride stress corrosion. The high cost of performing a full inspection resulted in the decision to permanently shut down operations and begin dismantling. The decommissioning and shipping of the NPP and contaminated soil back to the U.S. occurred between 1974 and 1979.

This assessment focuses on veterans who were not externally and internally monitored for radiation exposure. These non-monitored veterans were defined as support personnel to differentiate them from veterans who worked at the NPP and received external and internal radiation monitoring. Dose assessment for NPP workers is performed on an individual basis owing to the availability of individual radiation monitoring records, and is only briefly addressed in this report.

In this assessment for McMurdo Station support personnel, doses from sources outside the body and those inside the body are calculated. The main sources of radiation outside the body include sources from the NPP, e.g., the reactor, radioactive waste, radioactive effluent, radioactive materials in passing plumes, and contaminated soil deposited on the ground. The sources of radiation inside the body are radioactive materials that deposit in tissues and organs after breathing air and ingesting water, and soil and dust that have been contaminated with radioactive materials. For external dose calculations, estimated radiation dose rates are used for various locations where veterans could have been exposed. For internal dose calculations, measurements of radioactivity in air, water, and soil are used with internationally accepted dose models recommended by the International Commission on Radiological Protection (ICRP) (ICRP, 1994a-b).

The quantities calculated in this report are whole body effective dose and total equivalent doses to the thyroid gland and red bone marrow as defined in ICRP Publication 60 (ICRP, 1991). The thyroid and red bone marrow selections were considered the best representatives of the human body organs that might be affected by the NPP radiation sources. The effective dose is a 
radiation protection quantity that allows external and internal doses to be combined to obtain an estimate of overall possible health risk from exposure to radiation. The total equivalent dose to the thyroid gland is from external and internal radiation sources and is important in assessing the potential disease of this organ. The total equivalent dose to the red bone marrow is similarly from external and internal radiation sources and is important in assessing diseases of the blood and bone marrow.

The calculated upper-bound total effective doses for support personnel at the McMurdo Station range from 0.2 to 0.6 rem ( 2 to 6 mSv) per tour. The calculated upper-bound total equivalent doses to the thyroid and red bone marrow, the two organs that could have received the highest organ doses, range from 0.2 to 0.6 rem ( 2 to $6 \mathrm{mSv}$ ) per tour. These doses are low and the associated probability that disease could have arisen from these doses is also low. For comparison, at effective doses less than 5 to 10 rem (50 to $100 \mathrm{mSv}$ ), risks of health effects are either too small to be observed or nonexistent (HPS, 2010).

Finally, to assist McMurdo Station veterans, their dependents, the VA, and the Naval Dosimetry Center, this report includes recommendations for the filing of VA compensation claims for diseases potentially arising from radiation exposure, and information and procedures for processing these claims. Specific recommendations are provided for first time filers, veterans previously denied VA service connection, and surviving spouses or children of a deceased McMurdo Station veteran. 


\section{DTRA-TR-12-003(R1): Upper-Bound Radiation Dose Assessment for Military Personnel at McMurdo Station, Antarctica, between 1962 and 1979, (Revision 1)}

\section{Table of Contents}

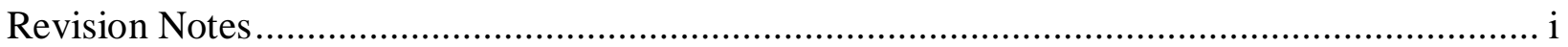

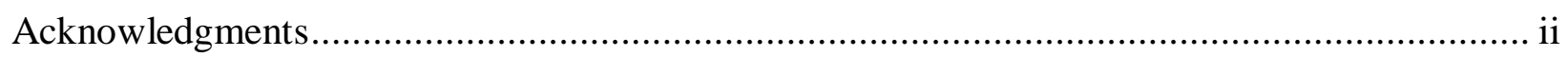

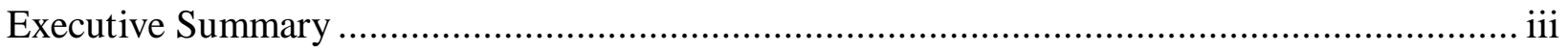

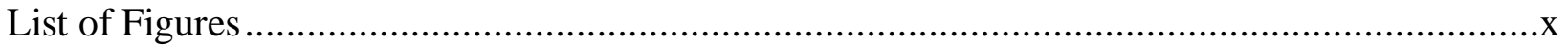

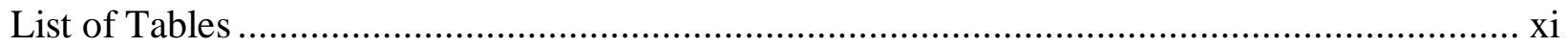

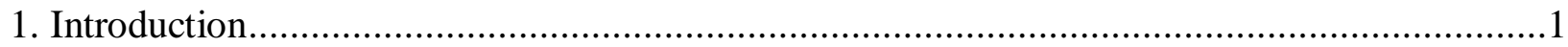

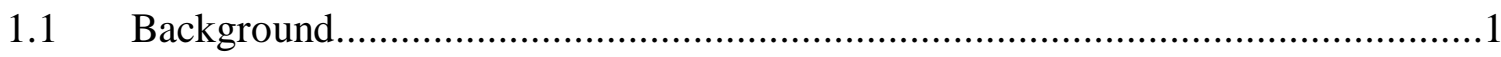

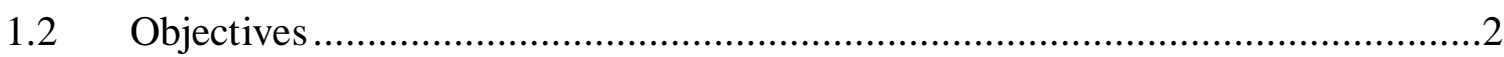

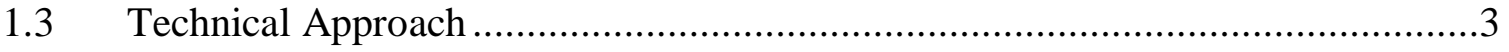

2. History of the McMurdo Station Nuclear Power Plant ......................................................5

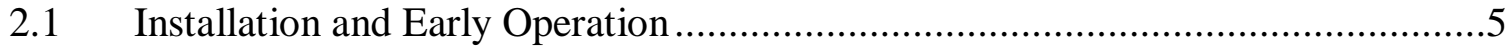

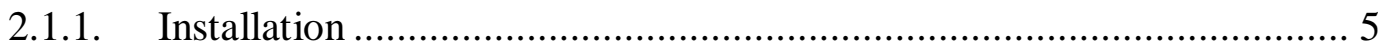

2.1.2. Early Operation.................................................................... 5

2.2 Operations and Maintenance ............................................................. 11

2.2.1. Environmental Radiation Surveillance Program .................................11

2.2.2. Radiation Safety Standards........................................................12

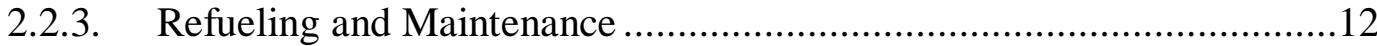

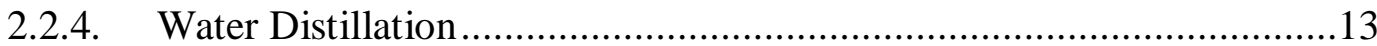

2.2.5. Malfunction History and Characteristics........................................13

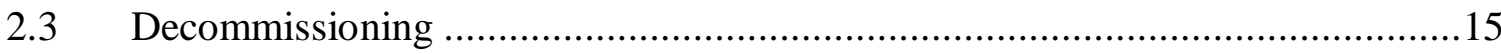

2.3.1. Removal and Shipment of Plant Components and Contaminated Soil...15

2.3.2. Radioactive Waste......................................................................16

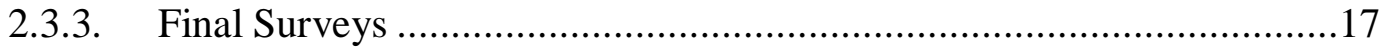

3. Potential Sources of Radiation Exposure for Support Personnel........................................19

3.1 External Gamma and Neutron Radiation ..................................................19

3.1.1. Radiation Sources inside the NPP ................................................19

3.1.2. $\quad$ Radiation Sources while Transiting Near the NPP .............................20

3.1.3. Immersion in Radioactive Noble Gases ..............................................20 
3.1.4. Movement of Packages Containing Radioactive Materials outside the NPP

3.1.5. Movement of Radioisotope Thermal Generators....................................20

3.1.6. Loading of Radioactive Waste..............................................................21

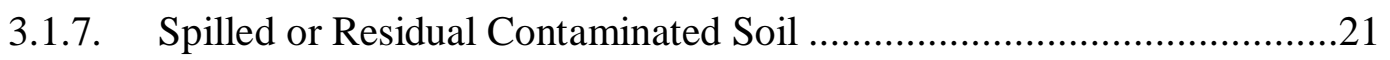

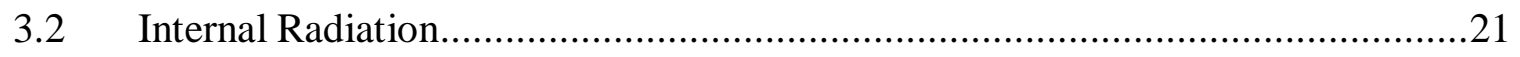

3.2.1. Inhalation of Airborne Radioactive Materials from Emissions Released through the NPP Stack and Worldwide Fallout......................................22

3.2.2. Inhalation of Suspended Soil Contaminated with Radioactive Materials .22

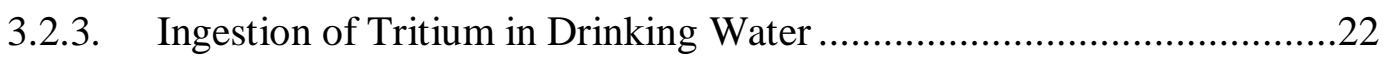

3.2.4. Ingestion of Radioactive Materials in Drinking Water other than Tritium

3.2.5. Incidental Ingestion of Soil and Dust Contaminated with Radioactive

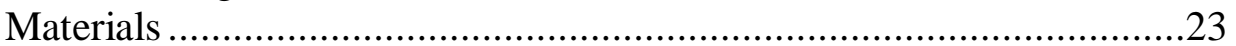

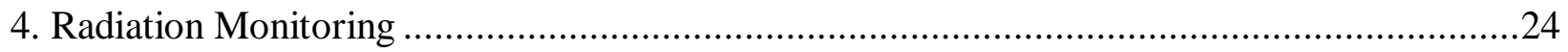

4.1 Exposure Records of Reactor Personnel .........................................................24

4.2 External Radiation Measurements ....................................................................25

4.3 Airborne Activity Concentrations....................................................................27

4.4 Radioactivity Concentrations in Water ..............................................................30

$4.5 \quad$ Radioactivity Concentrations in Soil ...............................................................32

4.6 Removable Radioactivity on Surfaces ...........................................................33

4.7 Radiation Levels of Radioactive Waste Shipments ................................................33

5. Dose Assessment Methodology and Assumptions for Support Personnel...................................34

$5.1 \quad$ External Dose Methods and Assumptions................................................................34

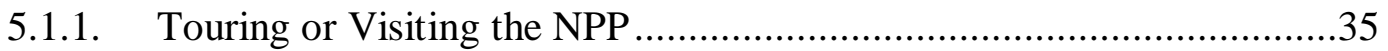

5.1.2. Transits in the Proximity of the NPP ...................................................37

5.1.3. Immersion in a Cloud of Noble Gases …………………………...........39

5.1.4. Proximity to Radioactive Waste Packages .............................................40

5.1.5. Proximity to Radioisotope Thermal Generators ......................................41

5.1.6. Contaminated Soil on the Ground.........................................................42

5.1.7. Ship Loading of Radioactive Waste......................................................43

5.2 Internal Doses-Methods and Assumptions .....................................................44

5.2.1. Inhalation of Airborne Radioactive Materials .........................................44 
5.2.2. Inhalation of Suspended Contaminated Soil during Decommissioning..47

5.2.3. Inhalation of Suspended Contaminated Soil Spilled on the Ground, Roads and Ship Loading Areas.............................................................48

5.2.4. Ingestion of Tritium in Drinking Water ...............................................49

5.2.5. Ingestion of Long-Lived Beta Emitters in Drinking Water other than

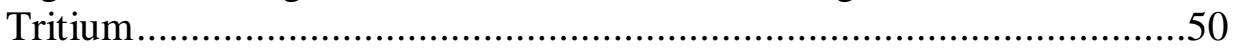

5.2.6. Incidental Ingestion of Contaminated Soil and Dust .............................51

$5.3 \quad$ Uncertainties and Upper-Bound Doses ..........................................................52

5.3.1. External Doses ..................................................................................

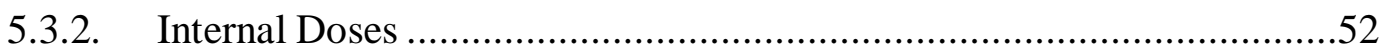

6. Support Personnel Dose Assessment Results and Discussion.................................................54

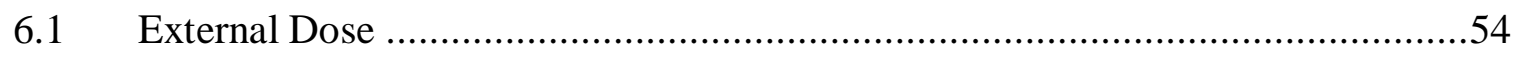

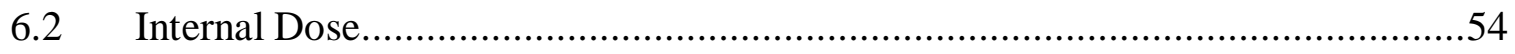

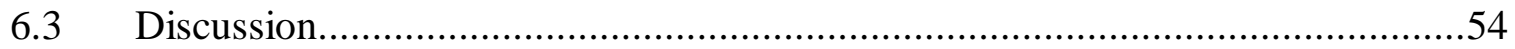

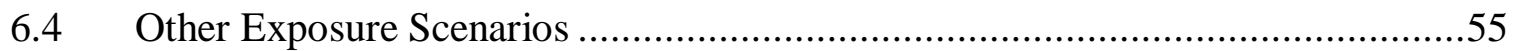

6.5 Comparative Radiation Exposures in Daily Life .................................................60

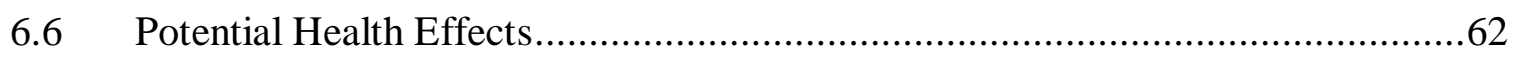

7. Radiation Dose Assessment for Reactor and Decommissioning Crew Members ....................63

7.1 Sources of External Radiation Exposure...............................................................63

7.1.1. Reactor Crew Members during NPP Operation .....................................63

7.1.1.1 Radiation Sources at the NPP Facility while on Duty .............63

7.1.1.2 Radiation Sources while off Duty...........................................63

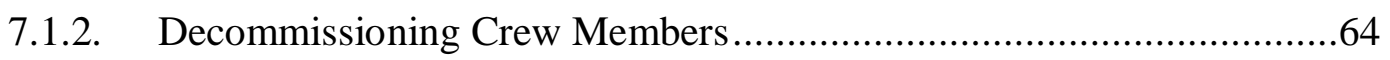

7.1.2.1 Radiation Sources at the NPP Facility while on Duty .............64

7.1.2.2 Radiation Sources while off Duty.............................................64

7.2 Sources of Internal Radiation Exposure..............................................................64

7.2.1. Reactor Crew Members during NPP Operation .....................................64

7.2.1.1 Inhalation of Airborne Radioactive Materials while inside the NPP .64

7.2.1.2 Inhalation of Airborne Radioactive Materials while outside the NPP …........................................................................64

7.2.1.3 Ingestion of Drinking Water ..................................................65

7.2.2. Decommissioning Crew Members..........................................................65

7.2.2.1 Inhalation of Airborne Radioactive Materials while on Duty .65 
7.2.2.2 Inhalation of Airborne Radioactive Materials while off Duty.65

7.2.2.3 Ingestion of Drinking Water ...................................................65

7.2.2.4 Incidental Ingestion of Contaminated Soil and Dust ...............65

7.3 Dose Estimation Methodology ………………............................................66

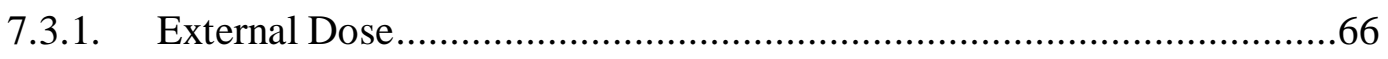

7.3.2. Inhalation of Airborne Radioactive Materials .......................................66

7.3.3. Ingestion of Radioactive Materials ......................................................67

8. Recommendations for Radiogenic Disease Claim Process ………………….......................68

8.1 Guidance for the Radiogenic Disease Claim Process ...........................................68

8.1.1. For McMurdo Station Veterans who are First Time Filers .....................68

8.1.2. For McMurdo Station Veterans Previously Denied VA Service

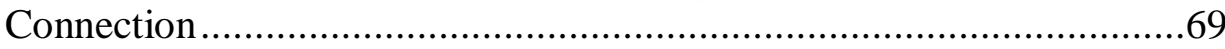

8.1.3. For a Surviving Spouse of a Deceased McMurdo Station Veteran ........69

8.1.4. For the Veterans Benefits Administration (VBA) ...................................69

8.1.5. For Director, Environmental Agents Service, Veterans Health Administration (VHA) ..................................................................

8.1.6. For the Naval Dosimetry Center ........................................................70

8.2 Proposed Guidelines for Individual Radiation Dose Assessment for McMurdo

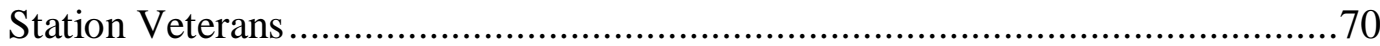

8.2.1. Assignment to Appropriate Group and Collection of Information ..........70

8.2.2. Individual Dose Assessment for Support Personnel ................................70

8.2.3. Individual Dose Assessment for Reactor Crew Members........................71

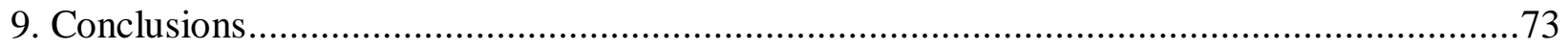

9.1 Summary of Assessment Approach ..................................................................73

9.2 Dose Assessment Results and Health Risks .........................................................74

9.3 Recommendations for Radiogenic Disease Claims Process ………………….....74

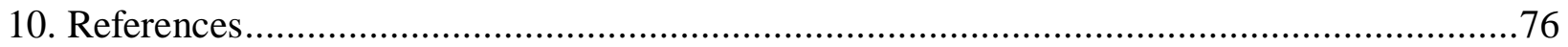

Appendix A. Congressional Inquiries Regarding Veterans' Exposures to Radiation from the McMurdo Station Nuclear Power Plant ............................................................. 81

A-1. Letter from Senator Brown to Secretary of Defense …………….......................82

A-2. DoD Response to Senator Brown. .....................................................................83

A-3. Letter from Senator Blumenthal to Assistant Secretary of the Navy (Installations

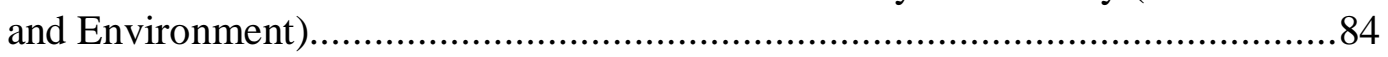

A-4. Department of the Navy Response to Senator Blumenthal..................................85 
Appendix B. Radiation Dose Calculation Methods and Parameter Definitions .87

B-1. External Dose Assessment Methods and Parameter Definitions ............................88

B-1.1. Average Hourly Dose Rate inside the NPP.......................................8

B-1.2. External Dose from Touring or Visiting the NPP ..............................88

B-1.3. External Dose from Transiting in Proximity to the NPP ....................89

B-1.4. External Dose from Immersion in a Cloud of Noble Gases ................89

B-1.5. External Dose from Movement of Radioactive Waste Packages outside the NPP .....................................................................................90

B-1.6. External Dose from Shipments of Radioisotope Thermal Generators 90

B-1.7. External Dose from Contaminated Soil on the Ground .......................91

B-2. Inhalation Dose Assessment Methods and Parameter Definitions ........................91

B-2.1. Inhalation of Airborne Radioactive Materials......................................91

B-2.2. Inhalation of Suspended Contaminated Soil during Decommissioning

B-2.3. Inhalation of Contaminated Soil on the Ground, Roads, and Ship Loading Areas ..............................................................................92

B-3. Ingestion Dose Assessment Methods and Parameter Definitions ........................93

B-3.1. Ingestion of Tritium in Drinking Water.............................................93

B-3.2. Ingestion of Other Long-Lived Beta Emitters in Drinking Water ......93

B-3.3. Incidental Ingestion of Contaminated Soil and Dust...........................93

B-4. Dose Uncertainty Methods and Parameter Definitions...........................................94

B-4.1. Uncertainty in External Doses............................................................94

B-4.2. Uncertainty in Internal Doses...........................................................94

Appendix C. McMurdo Station Radiation Dose Assessment Questionnaire .................................95

Abbreviations, Acronyms, and Unit Symbols ........................................................................119

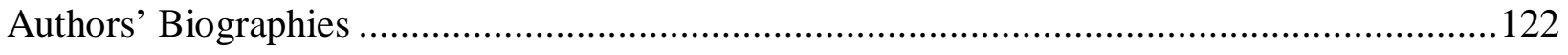




\section{List of Figures}

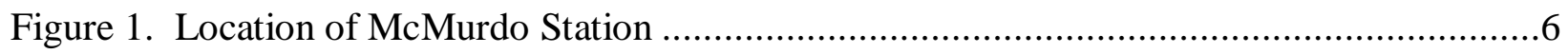

Figure 2. McMurdo Station in 1963 with the NPP on the side of Observation Hill....................7

Figure 3. The McMurdo Station NPP facility (pre-1973) .............................................

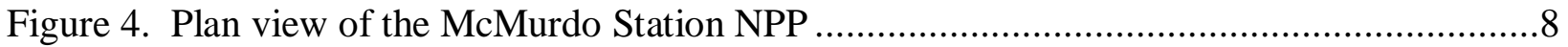

Figure 5. General arrangement of the equipment in the McMurdo Station NPP ......................9

Figure 6. Effluent discharge area at the McMurdo NPP ................................................10

Figure 7. Monthly average long-lived beta activity in 24-hour air samples ...........................29

Figure 8. Long-lived beta activity in monthly drinking water samples ................................31

Figure 9. Monthly average tritium activity in drinking water samples.................................32 


\section{List of Tables}

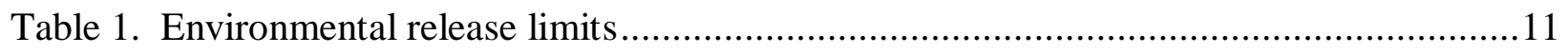

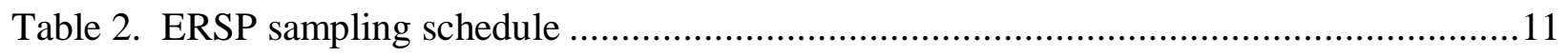

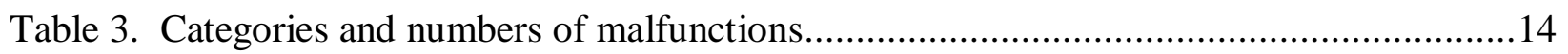

Table 4. Definitions of health physics, personal safety, and chemistry deviation types..............15

Table 5. Compiled dosimetry records for reactor crew members................................................26

Table 6. Self-reading dosimeter results for ship loading operations ...........................................27

Table 7. Monthly average of long-lived beta activity for 24-hour air samples ${ }^{*}\left(\mathrm{~Bq} \mathrm{~L} \mathrm{~L}^{-1}\right) \ldots \ldots \ldots \ldots . .28$

Table 8. Air samples taken during removal and loading of bulk contaminated soil ...................28

Table 9. Long-lived beta activity in monthly drinking water samples $\left(\mathrm{Bq} \mathrm{L}^{-1}\right)$........................30

Table 10. Monthly average tritium activity in drinking water samples $\left(\mathrm{Bq} \mathrm{L}^{-1}\right) \ldots \ldots \ldots \ldots \ldots \ldots \ldots . . . . .32$

Table 11. Parameter values and assumptions for estimating average dose rates inside the NPP

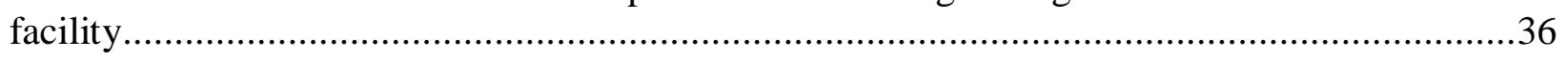

Table 12. Parameter values and assumptions for external dose while visiting the NPP...............36

Table 13. Estimated average dose rate inside the NPP .............................................................37

Table 14. Parameter values and assumptions for external dose for support personnel transiting near the NPP fence line ....................................................................................................38

Table 15. Parameter values and assumptions for external dose from immersion in radioactive

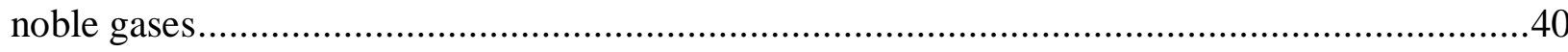

Table 16. Parameter values and assumptions for external dose from proximity to radioactive waste packages.................................................................................................................

Table 17. Parameter values and assumptions for exposure to external radiation from shipments

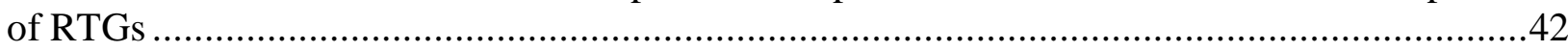

Table 18. Parameter values and assumption for the external dose from contaminated soil deposited on the ground during decommissioning .................................................................42

Table 19. Parameter values and assumptions for external dose for ship loading of radioactive waste.

Table 20. Parameter values and assumption for the internal dose from inhalation of airborne radioactive materials from stack emissions or worldwide fallout

Table 21. Parameter values and assumption for the internal dose from inhalation of suspended contaminated soil during decommissioning .....

Table 22. Parameter values and assumptions for the internal dose from inhalation of suspended contaminated soil that was spilled on the ground, roads and ship loading areas..........................48

Table 23. Parameter values and assumptions for the internal dose from ingestion of tritium in drinking water 
Table 24. Parameter values and assumptions for the internal dose from ingestion of long-lived beta emitters in drinking water other than tritium .................................................................50

Table 25. Parameter values and assumptions for the internal dose from incidental ingestion of

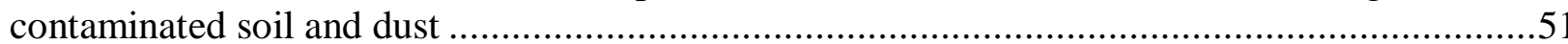

Table 26. External doses and upper-bounds for winter-over support personnel ..........................56

Table 27. External doses and upper-bounds for austral summer support personnel ....................56

Table 28. Internal doses and upper-bounds for winter-over support personnel ..........................57

Table 29. Internal doses and upper-bounds for austral summer support personnel.......................58

Table 30. Upper-bound external, internal, and total doses for McMurdo Station support personnel during Deep Freeze years 1962 to 1979 ...................................................................60

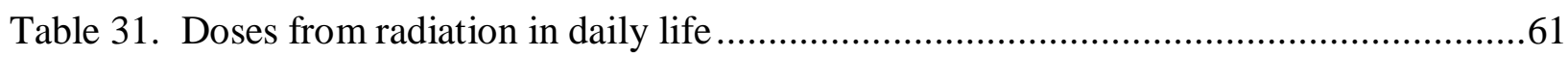

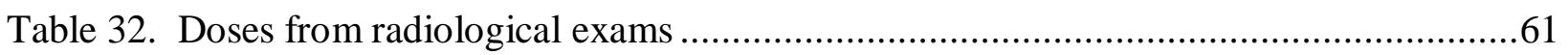




\section{1.}

\section{Introduction}

This report presents the results of the radiation dose assessment (RDA) for the few thousand U.S. Department of Defense (DoD) military personnel who were stationed at McMurdo Station, Antarctica, during Operation Deep Freeze (DF) between 1962 and 1979. During this period, an onsite nuclear power plant (NPP) was built, operated to generate electricity and steam for water distillation, and finally dismantled and decommissioned. There are two groups or populations that are addressed in this report. The first group is the support personnel comprised of individuals who were stationed at McMurdo Station but not assigned to the NPP. The second group consists of the reactor crew members who are defined as those individuals who were stationed at McMurdo Station and assigned to the NPP. The two groups differ since reactor crew members were individually monitored for occupational exposure to ionizing radiation whereas support personnel were not monitored.

In this assessment, upper-bound doses were estimated for the support personnel group. The dose estimation included an assessment of potential external and internal sources of radiation. Also, for this report, a review of reported doses for reactor crew members was carried out. Specific individualized dose assessments for support personnel and reactor crew members can be performed through a proposed RDA procedures framework introduced in Section 8 of this report, which will be further detailed in a separate document.

\subsection{Background}

The McMurdo Station is located 850 miles from the South Pole. The U.S. Navy operated the NPP from March 1964 to October 1972. The NPP was built and initially operated by engineers from the Martin Company, Atomic Energy Commission personnel, and military representatives. The NPP arrived at McMurdo Station in December 1961, achieved criticality on March 4, 1962, and was transferred to the control of the U.S. Navy in March 1964. The reactor was shut down in 1972 when water was detected in the normally dry canning surrounding the primary plant piping. It was determined that this water was due to leaks from the primary shield tank into the canning. Because the insulation in the canning contained chlorides, the possibility of chloride stress corrosion created the need for a detailed inspection that confirmed that the insulation has been wetted. The high cost of performing a full inspection of the primary plant for stress corrosion resulted in the decision to permanently shut down operations. The U.S. Navy operated the NPP in standby mode, i.e., the reactor was subcritical until the decision was made to decommission it. The defueling and decommissioning occurred from October 1973 to March 1979. A detailed history of the NPP is found in Foster and Jones (1982) and Naval Nuclear Power Unit (NNPU) (1973a).

In March 2011, Senator Brown of Ohio requested that the Secretary of Defense work with the Department of Veterans Affairs (VA), the Veterans' Advisory Board on Dose 
Reconstruction (VBDR), and any other relevant parties to review existing methods used to evaluate the probability of radiation exposure at McMurdo Station causing an existing cancer (probability of causation) in veterans (Brown, 2011). The Under Secretary of Defense for Personnel and Readiness (USD(P\&R)) responded in May 2011 and stated that the DoD would work with these organizations to address any questions related to radiation exposures at McMurdo (USD/P\&R, 2011). Appendix A includes copies of the letters received from Senator Brown and the response from the DoD.

In July 2011, Senator Blumenthal of Connecticut requested the Assistant Secretary of the Navy for Energy, Installations, and Environment (ASN(E, I\&E)) to work with the VA, the VBDR, and other relevant parties to review potential radiation exposures at McMurdo Station (Blumenthal, 2011). Later in July 2011, the ASN(E, I\&E) responded that the Navy would work with the VA, the VBDR, and the Defense Threat Reduction Agency (DTRA) to address the McMurdo issue (ASN(E, I\&E), 2011). Appendix A includes copies of the letters received from Senator Blumenthal and the response from the U.S. Navy.

In response to veterans' concerns, the DoD assembled an integrated project team of military, civilian, and contract radiation dose assessment experts from DTRA and the U.S. Navy, and knowledgeable McMurdo Station crew members to review the available information and to determine the potential health effects to military personnel exposed to ionizing radiation at McMurdo Station. In addition, it was agreed that the assessment team would work with the VA and VBDR throughout this process. Biographies of this report's authors are provided at the end of this document.

The results of the DoD preliminary radiation dose assessment were presented at the VBDR's annual meeting held on March 23-24, 2012, in San Antonio, TX. Lieutenant Commander (LCDR) Gregory R. Fairchild, Naval Dosimetry Center, briefed the VBDR on the initial results of the radiation dose assessment (Fairchild, 2012a). During the briefing, LCDR Fairchild mentioned to the audience that whoever would be willing to provide additional input to the study on any experience they may have had during their time at McMurdo Station should contact the members of the radiation dose assessment team (VBDR, 2012). Several members of the audience related personal experiences at McMurdo Station during the public comment session and several veterans provided input following the meeting. Veterans' experiences and input were used in revising the dose assessment. Prior to the VBDR meeting, the Subcommittee on Dose Reconstruction Procedures (Subcommittee 1) of the VBDR conducted a preliminary review of the dose assessment effort for the McMurdo Station. The members of Subcommittee 1 found that the methodology developed was sound and agreed to review the revised version of the report (VBDR, 2012; Fairchild, 2012a).

\subsection{Objectives}

The main objective of the assessment documented in this report is to estimate upper-bound radiation doses for McMurdo Station military support personnel that includes an evaluation of potential exposures while working and living at the Station, and exposures that would have resulted from sources of radiation associated with the NPP during its construction, operation, and decommissioning. The upper-bound radiation doses were estimated for groups stationed at McMurdo during winter-over (12-14 months) and austral summer (6 months or less) starting in December 1961 (DF 62) until March 1979 (DF 79 summer). 
In addition to the estimating doses accrued by support personnel, a procedural framework for individualized dose assessments for both support personnel and reactor crew members was developed. Furthermore, the potential health effects due to radiation exposures at the McMurdo Station were evaluated.

It is important to note that the present dose assessment does not address exposures from radioactive sources at other stations or facilities in Antarctica. It does not include exposures to crewmembers aboard the ships that brought in the nuclear fuel rods to the McMurdo Station and carried away radioactive waste or spent fuel rods back to the United States. Also, the present assessment does not include exposures to radiation from sources used by civilian researchers at the station. The other sources of possible exposure to radiation could be addressed in individualized dose assessments, if needed.

\subsection{Technical Approach}

The assessment described in this report is designed to estimate very conservative external and internal radiation doses, and corresponding upper-bound doses received by support personnel who served at McMurdo Station for the years and activities mentioned above. Highsided conservative parameter values are selected to reflect the top of the range of plausible values. High-sided parameter values are not considered to be the worst case. The upper-bound dose is estimated to be at least as high as the $95^{\text {th }}$ percentile dose based on comparisons of similar assessments using a probabilistic analysis that accounts for uncertainties in the determination of dose distributions.

Standard dose reconstruction techniques used in the dose assessment are based on standard procedures and methods developed for other veterans' radiation dose assessment programs, e.g., the DTRA Nuclear Test Personnel Review Program (DTRA, 2010). The internal doses calculated are the 50-year committed effective dose, the 50-year committed equivalent dose to the thyroid, and 50-year committed equivalent dose to the red bone marrow.

The following steps were adopted as part of the approach to develop the upper-bound radiation dose assessment for support personnel:

1) Review historical information of reactor operations at the NPP to include design, routine operations, incidents, and occupational exposures.

2) Collect information from veterans and U.S. Navy organizations that were involved in either the NPP operation or decommissioning with emphasis on finding information on radiation measurements, effluent releases, incidents, and radiation safety procedures.

3) Compile and evaluate available occupational dosimetry data of exposed reactor personnel.

4) Use the historical data and information provided by veterans to develop exposure scenarios and pathways of exposure for all potential NPP radiation sources for both winter-over and austral summer personnel.

5) Estimate very conservative external and internal doses and corresponding upper-bounds for McMurdo Station support personnel for all exposure pathways using standard dose reconstruction techniques. 
6) Compare the estimated total doses to other types of radiation exposures and determine potential health effects.

7) Propose dose assessment procedures for the determination of an individual service member's dose for either the support personnel or reactor crews. 


\section{History of the McMurdo Station Nuclear Power Plant}

\subsection{Installation and Early Operation}

\subsubsection{Installation}

The McMurdo Station NPP was the PM-3A, a portable medium size type 3A, that used a pressurized water nuclear reactor with a thermal output of 11.27 megawatts and an electrical output of 1.8 megawatts. The reactor used fuel elements that were pellet in rod construction and used water as the moderator. (Foster and Jones, 1982)

The McMurdo Station NPP was one of several NPPs constructed and operated by the DoD. Other reactors included the SM-1 at Fort Belvoir, Virginia; the SL-1 in Idaho Falls, Idaho; the PM-2A at Camp Century, Greenland; the PM-1 at Sundance, Wyoming; the SM-1A at Fort Greeley, Alaska; and the MH-1A operated on the USS Sturgis in the Panama Canal Zone. (DOE, 2001)

The NPP was located on the side of Observation Hill about 300 feet above McMurdo Station. The geographical situation and layout of the NPP facility are shown in Figure 1, Figure 2 and Figure 3. A plan view of the NPP and a schema of the equipment are given in Figure 4 and Figure 5. The layout of the effluent discharge area is shown in Figure 6.

The nuclear reactor of the NPP was installed in the Primary Building in a below ground tank and the steam generator was co-located with the reactor vessel in the same building. The radioactive waste disposal system was located in the Primary Building Addition. The electrical generators, control room, and the administrative offices were located in the Secondary Building. The condensers were in the Condenser Building. The Maintenance and Supply Building and the water distillation plant were located outside the main facility. The plant was designed to confine the areas of high radiation and high levels of radioactive contamination to the primary building, the primary building addition, and to the primary yard inside the perimeter fence. (Foster and Jones, 1982)

\subsubsection{Early Operation}

Construction of the NPP started in December 1961 on the side of Observation Hill east of McMurdo Station. The plant components, including the first reactor core, arrived at McMurdo Station on December 13, 1961, with completion of the unloading and hauling of the NPP reactor components occurring on December 29, 1961. The reactor achieved criticality for the first time on March 4, 1962. A detailed description of the planning and construction of the NPP can be found in Foster and Jones (1982). The plant started producing electricity in July 1962 and was operated by Navy crews under the direction of employees of the Martin Company and 
representatives of the Atomic Energy Commission (AEC) (now superseded by the U.S. Nuclear Regulatory Commission). Since the reactor was the first of its type designed for field use, it took two years during early operation to complete evaluation and debugging before the U.S. Navy assumed operational control and took custody of the plant in March 1964 (Foster and Jones, 1982).

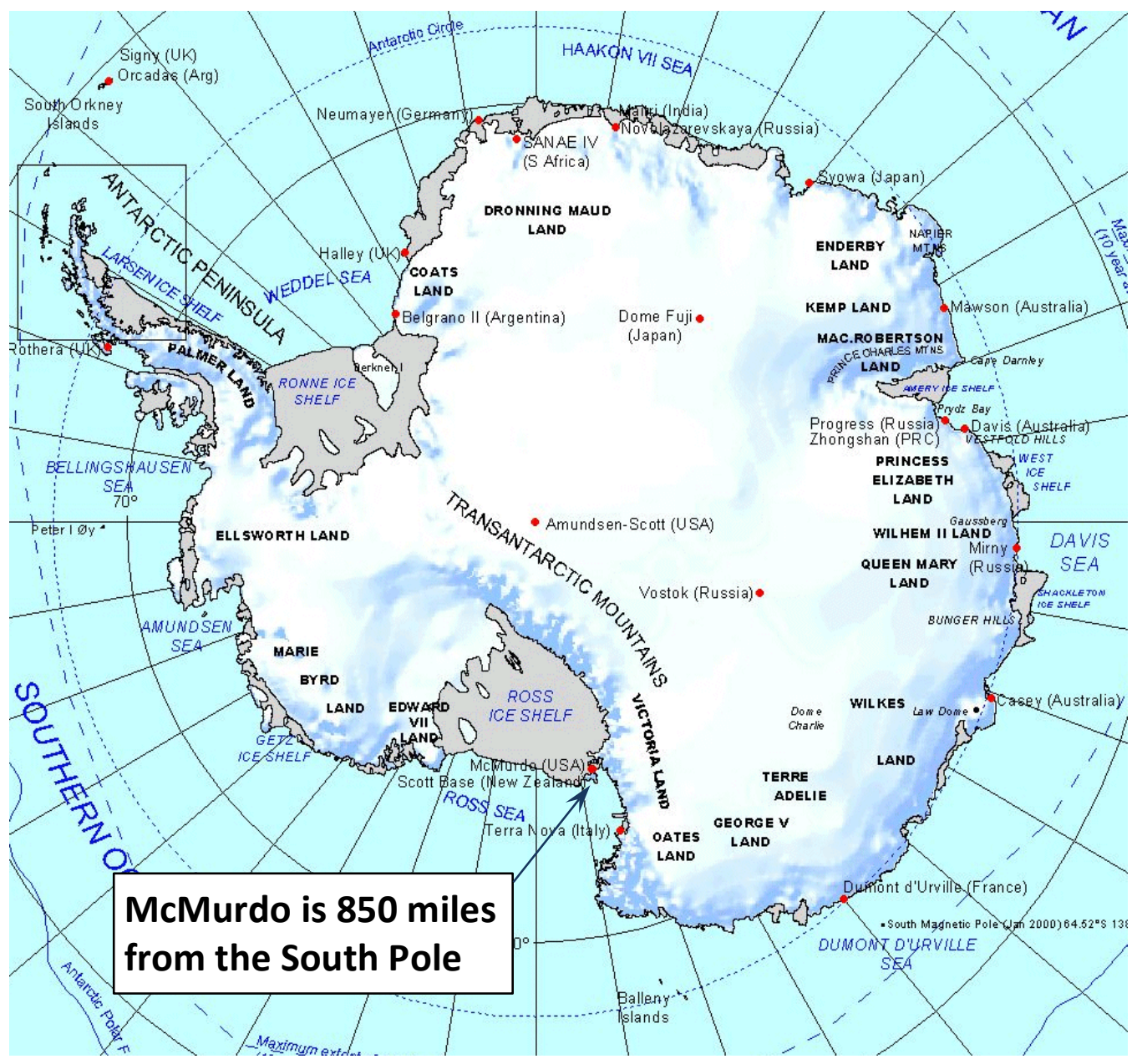

Figure 1. Location of McMurdo Station 


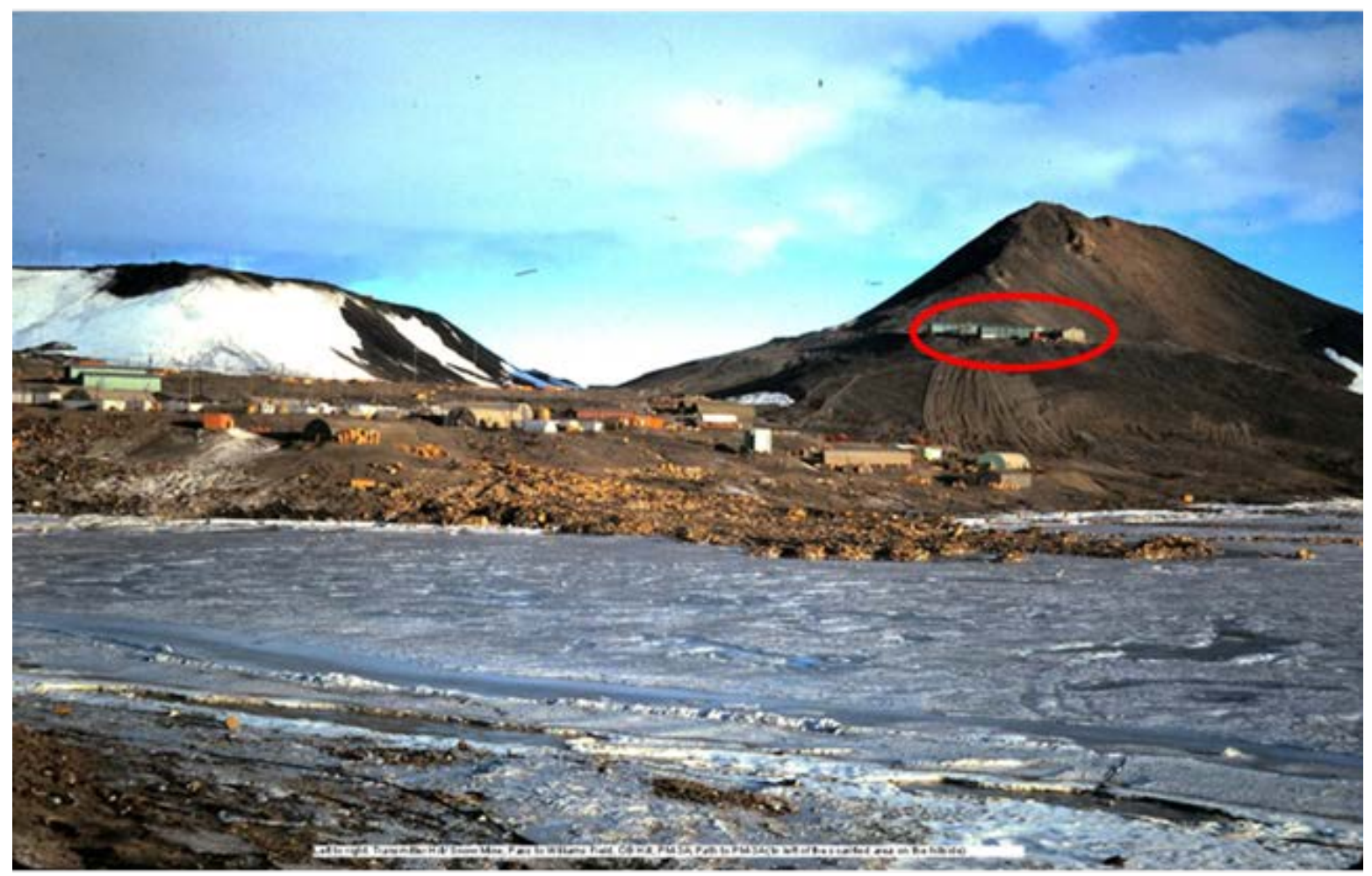

Figure 2. McMurdo Station in 1963 with the NPP on the side of Observation Hill

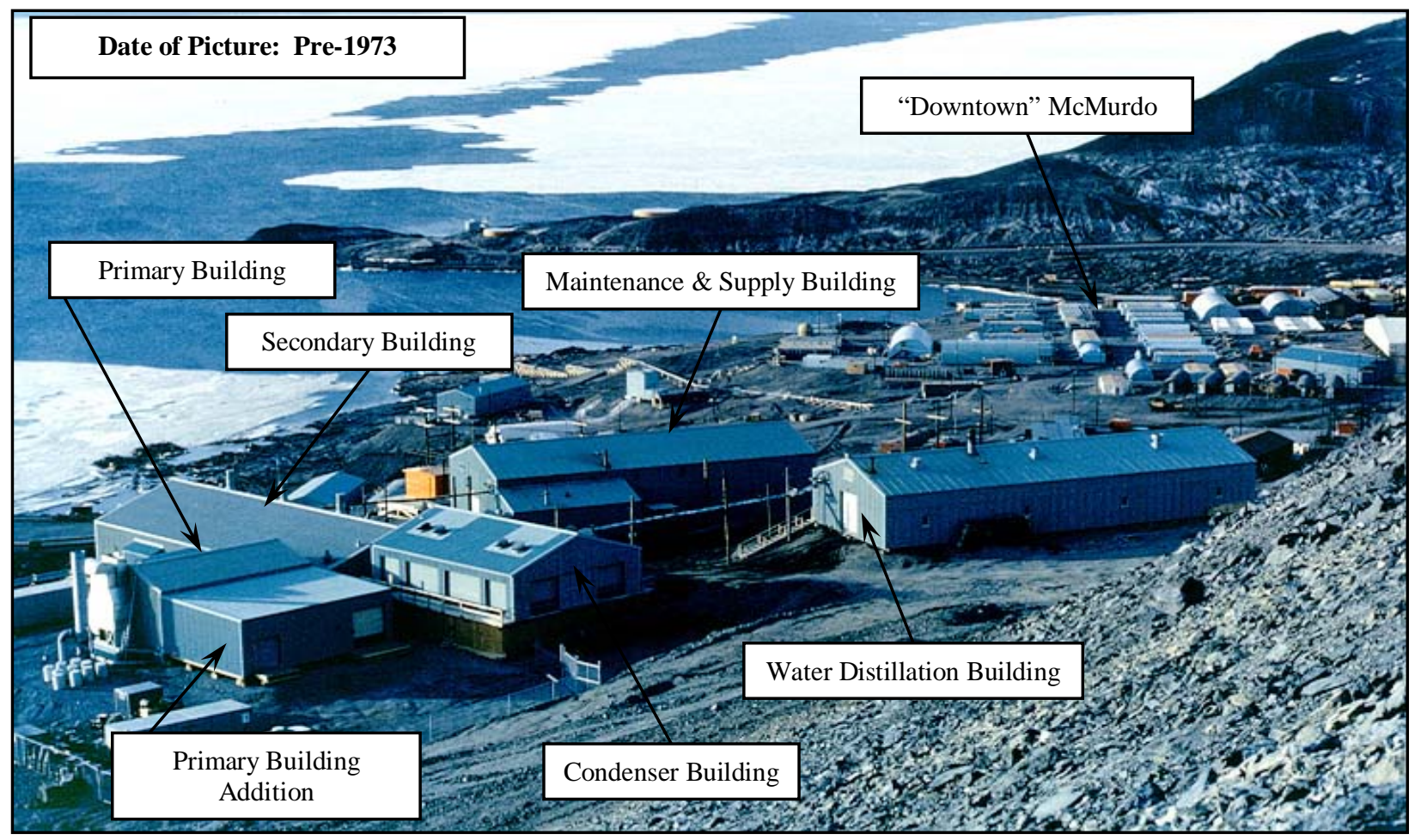

Figure 3. The McMurdo Station NPP facility (pre-1973) 


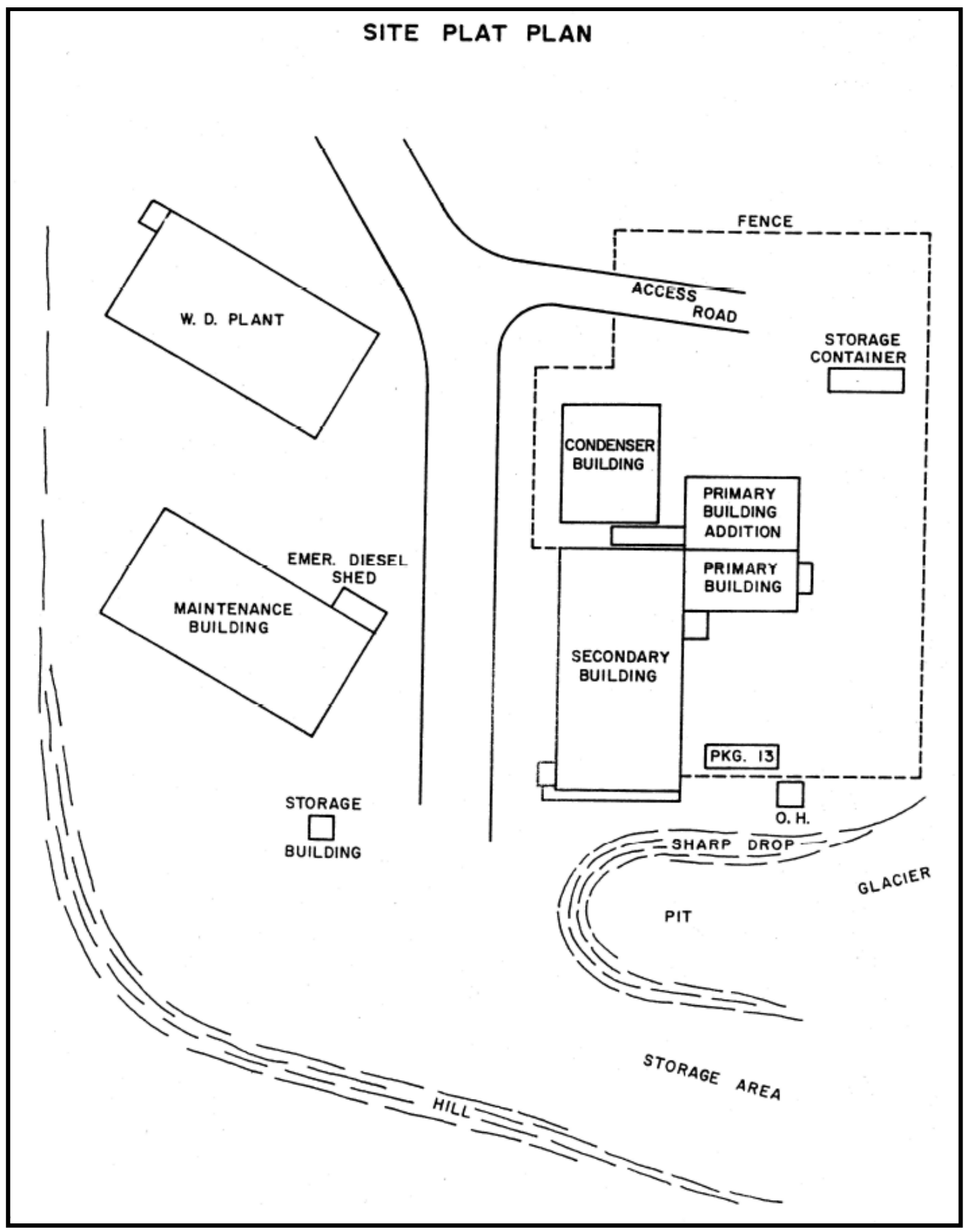

Figure 4. Plan view of the McMurdo Station NPP 


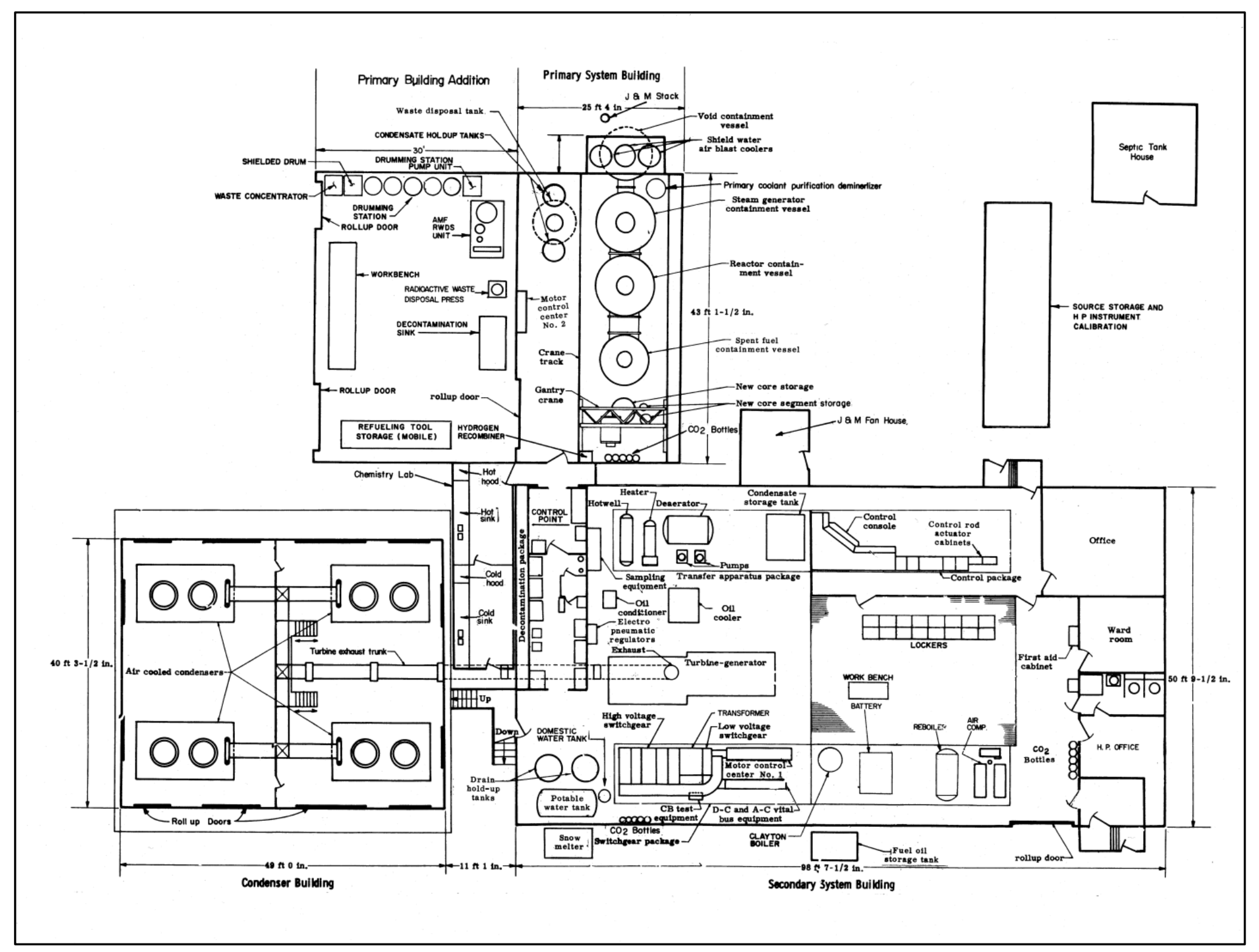

Figure 5. General arrangement of the equipment in the McMurdo Station NPP 


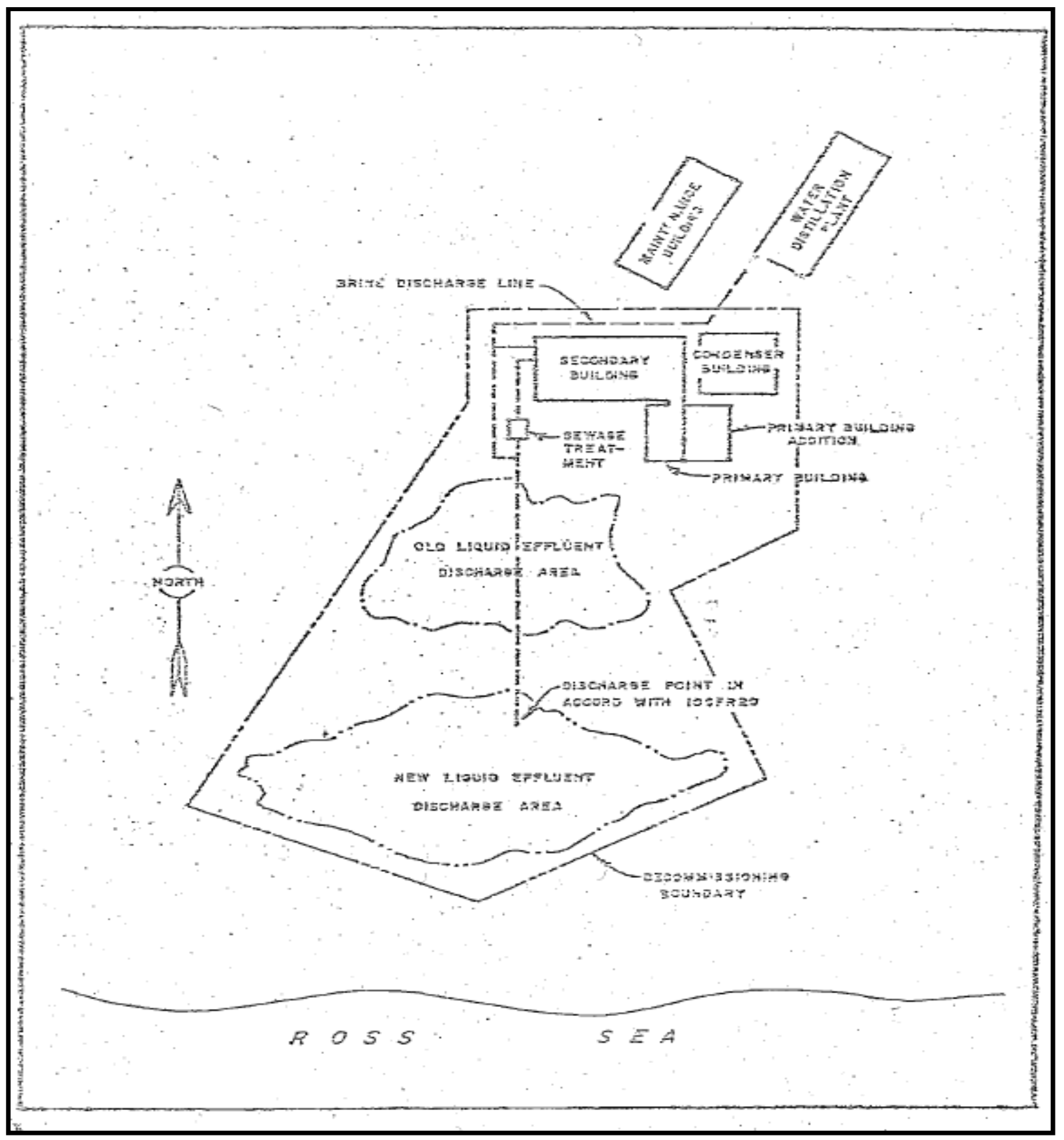

Figure 6. Effluent discharge area at the McMurdo NPP 


\subsection{Operations and Maintenance}

\subsubsection{Environmental Radiation Surveillance Program}

Operation of the McMurdo Station NPP followed the National Science Foundation recommendations for an Environmental Radiation Surveillance Program (ERSP). The operating criteria limits for environmental releases of radioactive materials from the NPP are listed in Table 1 (Foster and Jones, 1982). Many of the limits were intentionally set below the regulatory maximum release criteria that existed at the time of construction.

Table 1. Environmental release limits

\begin{tabular}{|l|l|}
\hline \multicolumn{1}{|c|}{ Type of Release } & \multicolumn{1}{c|}{ Criteria } \\
\hline Incidence of neutrons & 1 neutron $\mathrm{m}^{-2} \mathrm{~min}^{-1}$ at one mile from the NPP \\
\hline $\begin{array}{l}\text { Gaseous release of radioactive } \\
\text { materials exclusive of Ar-41 in effluent }\end{array}$ & $4 \times 10^{-14} \mu \mathrm{Ci} \mathrm{mL}{ }^{-1}\left(1.5 \times 10^{-9} \mathrm{~Bq} \mathrm{~mL}^{-1}\right)$ \\
\hline Liquid radioactive waste in effluent & $1 \times 10^{-7} \mu \mathrm{Ci} \mathrm{mL}^{-1}\left(4 \times 10^{3} \mathrm{~Bq} \mathrm{~mL}^{-1}\right)$ \\
\hline Ar-41 radioactive gas in effluent & $1 \times 10^{-8} \mu \mathrm{Ci} \mathrm{mL} \mathrm{mL}^{-1}\left(4 \times 10^{-4} \mathrm{~Bq} \mathrm{~mL}^{-1}\right)$ \\
\hline
\end{tabular}

In addition to the environmental release limits listed in Table 1, an ERSP environmental sampling program was developed by the U.S Public Health Service and continued by the U.S. Navy to determine if radiation and radioactivity levels were increasing due to the operation of the reactor. This program included monitoring melted snow and galley water and, starting in 1967, seawater and the drinking water that was produced in the distillation plant adjacent to the NPP. The water distillation plant used steam from the NPP. The types of samples and the frequency of their collection are listed in Table 2. (Foster and Jones, 1982)

Table 2. ERSP sampling schedule

\begin{tabular}{|l|l|}
\hline \multicolumn{1}{|c|}{ Type of Sample } & \multicolumn{1}{c|}{ Frequency } \\
\hline Air sample - long lived beta activity & $\begin{array}{l}\text { Continuous 24-hour samples at Building 63 in } \\
\text { the living quarters area }\end{array}$ \\
\hline Drinking water - long-lived beta activity & 1 sample monthly at the galley \\
\hline Sea water-long lived beta activity & 1 sample weekly at the distillation plant \\
\hline Drinking water - tritium & $\begin{array}{l}1 \text { sample weekly at the distillation plant (started } \\
\text { in 1967) }\end{array}$ \\
\hline Drinking water - tritium & $\begin{array}{l}1 \text { sample weekly at the galley } \\
\text { (started in 1967) }\end{array}$ \\
\hline Smear test & Weekly at the galley and living quarters \\
\hline
\end{tabular}




\subsubsection{Radiation Safety Standards}

The radiation safety standards published by the AEC were adhered to at the reactor facility even though such standards were not legally binding outside of the United States. The standards addressed release of radioactive materials into the environment and control of radiation levels in restricted and unrestricted areas. (USPHS, 1963)

To address radiation doses to personnel other than reactor crew, releases of radioactive materials from the reactor facility were not to exceed the limits set in Title 10, Code of Federal Regulations, Part 20 (10 CFR 20), Radiation Safety. Discharges of radioactive materials into the environment were only allowed if individuals at McMurdo Station were not likely to be exposed to concentrations in excess of the limits specified in 10 CFR 20, and an individual's exposure could not be averaged over periods greater than one year to determine compliance. (USPHS, 1963)

The external radiation levels in unrestricted areas had to be sufficiently low to ensure that no one would receive an external radiation dose in a year of more than $0.5 \mathrm{rem}(5 \mathrm{mSv})$. Radiation levels had to be below $0.002 \mathrm{rem} \mathrm{h}^{-1}\left(0.02 \mathrm{mSv} \mathrm{h}^{-1}\right)$ or less than 0.1 rem $(1 \mathrm{mSv})$ in any seven consecutive days. (USPHS, 1963)

Personnel monitoring was required for individuals who entered any radiation area defined as any area where an individual could receive a dose of greater than $0.005 \mathrm{rem}(0.05 \mathrm{mSv})$ in one hour or 0.1 rem $(1 \mathrm{mSv})$ in seven consecutive days. Personnel monitoring was also required for individuals who entered any high radiation areas defined as any area where an individual could receive a dose greater than $0.1 \mathrm{rem}(1 \mathrm{mSv})$ in one hour (USPHS, 1963).

The annual dose limits for reactor crew members and support personnel are not mentioned in the historical reports. During the time that the NPP was operational, the standard for occupational exposure to ionizing radiation was 3 rem $(30 \mathrm{mSv})$ per 13 weeks with a limit such that an occupational worker could not exceed a cumulative lifetime dose of $5 \times(\mathrm{N}-18)$ rem, where $\mathrm{N}$ is the age of the occupational worker. The standard for exposures for members of the general population to ionizing radiation was $0.5 \mathrm{rem}(5 \mathrm{mSv}$ ) per year (Jones, 2005).

\subsubsection{Refueling and Maintenance}

The reactor was refueled three times during its operational life. The refuelings occurred in October 1964, October 1967, and June 1970. The reactor was permanently defueled in July 1973. The NPP was built with a storage containment vessel to keep spent fuel before shipping it to the U.S. (Foster and Jones, 1982). Annual reactor and generator maintenance was usually performed during the austral summer when summer support personnel were available (Foster and Jones, 1982).

After the first refueling in October 1964, samples of the reactor spent fuel were sent to the Battelle Memorial Laboratory in Columbus, Ohio, for post-irradiation examination. The spent fuel rod examination was requested due to the increasing fission product accumulation in the primary coolant system. The examination determined that the fission product buildup was due to leakage through inter-granular cracks in the outer cladding of the fuel rods (Brown et al., 1967). 
The Battelle Memorial Laboratory report on the reactor spent fuel rods (Brown et al., 1967) was reviewed to determine if the leaking fuel rods could have created new, different, or unexpected sources of or pathways for radiation exposure for support personnel at McMurdo Station. The leaking fuel rods could have caused the amount of radioactive waste generated at the NPP to be relatively greater than otherwise expected or could have caused increased radiation releases of radioactive materials through the stack. These potential exposure pathways are addressed in the dose assessment using data from 1964. No additional pathways or sources of exposure were discovered that are unique to the leaking fuel rods.

\subsubsection{Water Distillation}

The McMurdo Station water distillation plant started using steam from the NPP in January 1967 as a heat source to produce drinking water from seawater. The reactor replaced an oil boiler as the heat source for water distillation. The water distillation plant continued to use steam from the NPP until the reactor was shut down in October 1972. The water distillation plant produced over 12 million gallons of water using steam from the NPP from 1967 to 1972. The use of steam from the NPP as a heat source for water distillation should not have resulted in increased exposure to individuals assigned to McMurdo Station. A drinking water monitoring program was started in January 1961 to measure beta-gamma radioactivity concentrations other than tritium in drinking water made from melted snow. The monitoring program continued after the distillation plant was built and began operations. Tritium monitoring was added to the monitoring program in 1967. (Foster and Jones, 1982)

\subsubsection{Malfunction History and Characteristics}

There were a total of 438 malfunctions and abnormal events of the NPP from March 12, 1964, to September 30, 1973, due to a variety of reasons (NNPU, 1973a). The categories and numbers of malfunctions are listed in Table 3. These malfunctions occurred after AEC turned over control of the NPP over to the U.S. Navy. There are no detailed records of malfunctions or abnormal events before the handover.

A review was made of the records that could be found for the 438 malfunctions to determine if any of the malfunctions could have led to increased exposures to support personnel or reactor personnel. The accounts of the malfunctions are found in Foster and Jones (1982) and give enough detail to determine if the malfunction could have increased radiation levels.

Several of the malfunctions would have increased the doses that reactor crew personnel received when extended maintenance on the reactor was needed, or production of more radioactive waste required handling and disposal. None of the incidents would have increased radiation levels outside of the NPP facility. Any increased doses to reactor personnel would have been measured and recorded by the film badges worn by reactor personnel. The malfunctions reviewed would have not increased the doses for support personnel above the doses calculated in this report. 
Table 3. Categories and numbers of malfunctions

\begin{tabular}{|c|c|}
\hline Category of Malfunction & Number of Malfunctions \\
\hline Nuclear instrumentation & 85 \\
\hline Process instrumentation & 48 \\
\hline Electrical & 83 \\
\hline Mechanical & 69 \\
\hline Control rod drive mechanism & 68 \\
\hline Operator error & 40 \\
\hline Miscellaneous & 45 \\
\hline Total & 438 \\
\hline
\end{tabular}

During operations at the NPP, reactor crews used the Health Physics Personal Safety and Chemistry (HPSC) Reports system to document reportable deviations from HPSC standards (Foster and Jones, 1982). There were eight types of reportable deviations that had to be documented using the HPSC reporting system. The definitions of the reportable deviations are listed in Table 4 (Foster and Jones, 1982). The deviations were reviewed to determine if they would have increased doses to support personnel. It was found that some of the deviations could have led to increased occupational doses to the reactor personnel. However, none of the deviations would have led to doses for the support personnel other than those due to the pathways considered in this report.

The four reports of radioactivity release to the environment in excess of operating limits (Type III reports) included: one incident of Xe-133 and Xe-135 the release that exceeded selfimposed plant limits but did not exceed 10CFR20 limits, one incident of contaminated water release from holdup tank number 4; one incident of the release of 200 gallons of water with a gross beta activity of $4.6 \times 10^{-2} \mu \mathrm{Ci} \mathrm{mL}{ }^{-1}\left(2 \times 10^{3} \mathrm{~Bq} \mathrm{~mL}^{-1}\right)$; and one incident where 2 gallons of water containing gross beta activity of $3 \times 10^{-2} \mu \mathrm{Ci} \mathrm{mL}^{-1}\left(1 \times 10^{3} \mathrm{~Bq} \mathrm{~mL}{ }^{-1}\right)$ spilled on the loading dock (NNPU, 1973a).

Furthermore, shielding water contaminated with radioactive materials leaked into the backfill surrounding the reactor vessel through cracks in the containment vessels. The leaks contaminated the surrounding soil that had to be removed during decommissioning. (Foster and Jones, 1982)

In addition to the malfunctions and deviations listed above, the reactor experienced a hydrogen fire in the containment tanks in October 1962. The fire led to equipment modifications and procedural changes (Foster and Jones, 1982). Since the fire occurred before the Navy assumed control of the reactor, the incident was not recorded or counted by the HPSC Reports system. Any increased dose from this incident would have been recorded by the film badges worn by reactor crew. 
Table 4. Definitions of health physics, personal safety, and chemistry deviation types

\begin{tabular}{|c|c|c|}
\hline Type & Definition & No. of Reports \\
\hline Type I & Injury to plant personnel or visitors & 14 \\
\hline Type II & $\begin{array}{l}\text { Exposure to personnel greater than } 0.350 \\
\text { rem ( } 3.5 \mathrm{mSv}) \text { in seven consecutive days }\end{array}$ & 123 \\
\hline Type III & $\begin{array}{l}\text { Release of any radioactivity to the } \\
\text { environment in excess of Title } 10 \text {, Code of } \\
\text { Federal Regulations, Part } 20\end{array}$ & 4 \\
\hline Type IV & $\begin{array}{l}\text { Increase of radiation or radioactivity levels } \\
\text { within the plant by more than a factor of } 3 \\
\text { from normal operating conditions }\end{array}$ & 11 \\
\hline Type V & $\begin{array}{l}\text { Water chemistry or radiochemistry analysis } \\
\text { outside of a limiting condition }\end{array}$ & 61 \\
\hline Type VI & $\begin{array}{l}\text { Inability to perform a required chemistry or } \\
\text { radiochemistry analysis }\end{array}$ & 5 \\
\hline Type VII & $\begin{array}{l}\text { Airborne particulate exposure to personnel } \\
\text { greater than } 3 \times 10^{-10} \mu \mathrm{Ci} \mathrm{mL} L^{-1} \\
\left(1 \times 10^{-5} \mathrm{~Bq} \mathrm{~mL} L^{-1}\right) \text { for any } 40 \text {-hour period } \\
\text { in seven consecutive days }\end{array}$ & 5 \\
\hline Type VIII & $\begin{array}{l}\text { Detection of airborne alpha activity greater } \\
\text { than } 2 \times 10^{-12} \mu \mathrm{Ci} \mathrm{mL}^{-1} \\
\left(7 \times 10^{-8} \mathrm{~Bq} \mathrm{~mL} \mathrm{~mL}^{-1}\right)\end{array}$ & 0 \\
\hline \multicolumn{2}{|r|}{ Total } & 223 \\
\hline
\end{tabular}

\subsection{Decommissioning}

\subsubsection{Removal and Shipment of Plant Components and Contaminated Soil}

The decommissioning of the McMurdo Station NPP was planned in 1973 and started at the beginning of DF 74. The decommissioning plan included the removal of the reactor vessel and reactor components, decontamination and removal of the primary building, and cleanup of the site to include removal of contaminated soil and rock. The original plan called for the NPP to be cleaned up during the austral summers of DF 74, 75, and 76. The actual cleanup lasted from DF 74 to 79 because decommissioning could only occur during the austral summers and because of the time needed to receive the analysis results of soil samples. (Foster and Jones, 1982)

During DF 74, the NPP's secondary systems were removed. In addition, the spent reactor fuel and 70 metric tons of radioactive waste were shipped to the United States. The reactor pressure vessel was also prepared for shipment by reactor crew personnel. (Foster and Jones, 1982)

During DF 75, the pressure vessel was prepared and shipped to the United States. To complete the removal, 2,300 metric tons of crushed rock backfill was removed from around the 
reactor containment tanks by reactor crew members. Over 365 metric tons of radioactive waste and equipment contaminated with radioactive materials were shipped to the United States.

(Foster and Jones, 1982)

During DF 76, the remaining equipment in the Secondary Building and the chemistry laboratory were dismantled. The foundation of the Primary Building was removed and the backfill cooling system around the reactor tanks was removed. The contaminated soil at the facility was surveyed and categorized in three groups based on levels of cesium-137 (Cs-137): soil contaminated with more than $2,000 \mathrm{pCi} \mathrm{g}^{-1}\left(74 \mathrm{~Bq} \mathrm{~g}^{-1}\right)$, soil with less than 2,000 $\mathrm{pCi} \mathrm{g}^{-1}$ $\left(74 \mathrm{~Bq} \mathrm{~g}^{-1}\right)$ but greater than $10 \mathrm{pCi} \mathrm{g}^{-1}\left(0.4 \mathrm{~Bq} \mathrm{~g}^{-1}\right)$, and soil with levels below $10 \mathrm{pCi}^{-1}$ $\left(0.4 \mathrm{~Bq} \mathrm{~g}^{-1}\right)$. Over 370 metric tons of radioactive waste to include boxed soil contaminated with radioactive materials and the steam generator containment vessel were shipped to the United States as radioactive waste (Foster and Jones, 1982). The radioactive waste and soil had to be shipped to the U.S. since radioactive waste could not be buried for disposal in Antarctica due to the Antarctic Treaty (Foster and Jones, 1982).

During DF 77, radiological surveys were completed for the remaining buildings and surveys of the contaminated soil continued. Over $5,000 \mathrm{~m}^{3}$ of contaminated bulk soil was shipped to the United States. Since the amount of contaminated soil exceeded the carrying capacity of the supply ship, $2,700 \mathrm{~m}^{3}$ of contaminated soil could not be shipped and was stored at the NPP facility until DF 78 when it was shipped to the United States (Foster and Jones, 1982).

During DF 78, surveys of the remaining contaminated soil were performed and $3,500 \mathrm{~m}^{3}$ of soil was shipped to the United States. The NUS Corporation conducted a final site survey of the NPP facility and other areas such as the effluent release areas (Foster and Jones, 1982).

During DF 79, soil with the highest level of Cs-137 contamination identified by the NUS Corporation survey during DF 78 was removed. More than $540 \mathrm{~m}^{3}$ of contaminated soil were removed and shipped in bulk to the United States (Foster and Jones, 1982).

The soil and rock at the NPP site were contaminated by several processes. First, there were three instances during plant operations when cracks in the containment vessels occurred. The cracks allowed shield water to leak into the crushed rock backfill surrounding the containment tanks. Second, backfill and soil near the buildings were contaminated by radioactive waste and water handling operations and other operations in the primary yard. Third, during normal plant operations, liquid effluent containing activity below maximum permissible concentration (MPC) set by the AEC was discharged and allowed to flow over the ground. Radioactive materials suspended in the effluent were absorbed into the rock and soil in the discharge area and concentrated in the first few centimeters. (Foster and Jones, 1982)

\subsubsection{Radioactive Waste}

Radioactive waste was generated during the operation of the NPP from 1962 to 1973 and during the decommissioning of the facility from 1973 to 1979 (Foster and Jones, 1982). According to the Antarctic Treaty, no radioactive waste could be disposed of in Antarctica (Foster and Jones, 1982). All radioactive waste had to be transported to the United States for disposal (USPHS, 1963).

Solid radioactive waste consisting of resins, cartridges, damaged reactor components, rags, paper, and contaminated laboratory equipment was produced over the course of operation 
of the NPP. The radioactive waste was shipped for disposal each austral summer during the operational phase of the plant. The radioactive waste was shipped to the United States in approved shipping containers such as Type A waste barrels and shielded shipping casks (Foster and Jones, 1982). Detailed records of the amounts and types of radioactive waste generated each year are not available.

An example of the type of radioactive waste shipped from McMurdo Station is the packing listings from DF 72. Such waste would be similar to waste generated and shipped to the United States in other operational years to include the shipment of a spent fuel core. The list of radioactive waste for that year includes 23 Department of Transportation drums, $17 \mathrm{H}$ drums in a Conex container, and Type A normal waste containers with a total weight of 2.27 ton (2100 kg and a volume of $10 \mathrm{~m}^{3}$ (U.S. Navy, 1972a). Solid waste resins were also shipped during DF 72 in two Type A, Special Form containers with a total weight of 25.4 metric tons. In addition, a spent fuel core of 17.2 metric tons and $18.5 \mathrm{~m}^{3}$ was shipped to the United States in 1972. (U.S. Navy, 1972a)

Liquid radioactive waste from the NPP was collected in a waste tank and processed using an evaporator. The condensate from the evaporator was held in a second tank for sampling. If the condensate was above effluent discharge concentration limits, it was recycled back to the evaporator. If the condensate was below release limits, it was discharged to the effluent discharge area. (Foster and Jones, 1982)

The gaseous radioactive waste from the reactor was vented through the discharge stack after passing through particulate and charcoal filters. The stack radiation detectors were in place to monitor the release of radioactive gases (Foster and Jones, 1982). However, no records of specific stack monitoring are available.

Four irradiated NPP reactor cores were returned to the United States. In addition, three cores were shipped to McMurdo Station but were not used in the NPP (Foster and Jones, 1982). The four irradiated, used cores were shipped to the Savannah River Plant, South Carolina. The three unused cores were returned to either the Savannah River Plant, South Carolina; the Nuclear Materials and Equipment Corporation in Apollo, Pennsylvania; or the National Lead Company in Crosby, Ohio. (Foster and Jones, 1982)

No major incidents or violations of federal or international regulations concerning radioactive waste occurred during the operation of the NPP (Foster and Jones, 1982). Seven incidents involving the shipment of radioactive waste were recorded. These include a leaking radioactive waste container, damaged radioactive waste containers, mismarked radioactive waste containers, and the mixing of radioactive waste with other dangerous goods, all occurring after the waste left McMurdo Station. These incidents are described in Foster and Jones (1982). A review of the incidents for this assessment concluded that none of these would have led to increased radiation exposure levels to support personnel since the incidents occurred after the packages left McMurdo Station or occurred inside the NPP.

\subsubsection{Final Surveys}

Two final surveys the original plan survey and the follow up survey, were performed during the decommissioning of the NPP. The first final survey was performed during DF 78 by the NUS Corporation (Jentz, 1978). The NUS report states that out of the 465 survey points, 285 
had soil concentration levels between 10 and $100 \mathrm{pCi} \mathrm{g}^{-1}\left(0.4 \mathrm{~Bq} \mathrm{~g}^{-1}\right.$ and $\left.4 \mathrm{~Bq} \mathrm{~g}^{-1}\right)$. Fourteen survey points were above $100 \mathrm{pCi} \mathrm{g}^{-1}\left(4 \mathrm{~Bq} \mathrm{~g}^{-1}\right)$ with the highest being $400 \mathrm{pCi} \mathrm{g}^{-1}\left(16 \mathrm{~Bq} \mathrm{~g}^{-1}\right)$. The NUS report was used to plan final decommissioning activities during DF 79 (Foster and Jones, 1982). A second final survey was performed during DF 79 by the U.S. Navy after the decommissioning efforts of DF 79 were completed. The average concentration in the soil over the site was $8 \mathrm{pCi} \mathrm{g}^{-1}\left(0.32 \mathrm{~Bq} \mathrm{~g}^{-1}\right)$ with highest concentration of Cs-137 in soil being $29 \mathrm{pCi} \mathrm{g}^{-1}$ $\left(1.2 \mathrm{~Bq} \mathrm{~g}^{-1}\right)$. (Foster and Jones, 1982) 


\section{3.}

\section{Potential Sources of Radiation Exposure for Support Personnel}

All support personnel stationed at McMurdo Station were potentially exposed to external gamma and neutron radiation, and internal radiation from the intake of radioactive materials by inhalation or ingestion. The applicability of potential sources of exposure for support personnel is based on their activities and their work and living locations. In this section, potential sources of external exposures are discussed first, followed by potential sources of exposures from internally-deposited radioactive materials.

\subsection{External Gamma and Neutron Radiation}

The support personnel at McMurdo Station worked and lived outside the NPP and could have been exposed to external gamma radiation from sources inside and outside the reactor facilities. The following sources of potential exposure to external radiation are considered for the support personnel at McMurdo Station:

1) Radiation sources inside the NPP while on a tour or visit of the plant. Such sources include the reactor vessel, contaminated reactor facility components and equipment, radioactive waste, packages containing radioactive materials, radioactive gases, and radioactive materials and contaminated soil in the effluent discharge area, and NPP yard.

2) Radiation sources inside the NPP facility while near the fence, such as when driving, hiking or walking by.

3) Immersion in indoor and outdoor air containing radioactive noble gases released from the NPP during operations.

4) Radioactive packages transported to or from the ship loading area outside the NPP facility.

5) Radioisotope thermal generators while being moved.

6) Radioactive waste during loading onto ships.

7) Contaminated soil spilled on the ground, roads and loading areas during decommissioning.

\subsubsection{Radiation Sources inside the NPP}

The support personnel at McMurdo were not routinely exposed to external gamma and neutron radiation while inside the NPP facility. However, some support personnel could have been exposed during visits to the NPP as part of their duties such as fire inspection (Armstrong, 
2012), or during occasional tours of the facility according to a previous officer-in-charge of the NPP (Fegley, 2012). To be conservative, all support personnel are assumed to have been exposed to this radiation source. Exposure to external radiation while inside the NPP could have occurred during all DF years.

\subsubsection{Radiation Sources while Transiting Near the NPP}

Support personnel could have been exposed to external gamma radiation from sources in or near the NPP facility while driving, hiking or walking near the NPP fence (Armstrong, 2012). As a conservative assumption, all support personnel are presumed to have been exposed to this radiation. Also, exposure to external radiation from this source is assumed to have occurred during any DF year an individual was at McMurdo Station.

\subsubsection{Immersion in Radioactive Noble Gases}

Support personnel could have been exposed to external gamma radiation during immersion in air containing radioactive noble gases outside of the NPP facility. The NPP released air containing Ar-41 at concentrations not greater than $1 \times 10^{-2} \mathrm{pCi} \mathrm{mL}^{-1}$ $\left(4 \times 10^{-4} \mathrm{~Bq} \mathrm{~mL}^{-1}\right)$. Ar-41 was produced in the NPP from the neutron activation of Ar-40 that is naturally present as $0.9 \%$ of air. The level of radioactive Xe-135 emissions exceeded the operating technical limits one time, but Ar-41 emissions never exceeded applicable limits (Foster and Jones, 1982). All support personnel who were assigned to McMurdo Station while the reactor was operational are assumed to have been exposed to this source of external radiation.

\subsubsection{Movement of Packages Containing Radioactive Materials outside the NPP}

Support personnel could have been exposed to external gamma radiation during the movement of radioactive packages to and from the NPP facility. These packages consisted primarily of radioactive waste. Except for the seven incidents referred to in Section 2 and reviewed separately, the radioactive waste packages are assumed to have been shipped in accordance with International Atomic Energy Agency (IAEA) requirements and were limited to external exposure rates acceptable for the labeling of the package (Foster and Jones, 1982). All support personnel are assumed to have been exposed to this radiation source. The radioactive waste packages would have contained fission products removed from the demineralizers of the primary coolant loop of the NPP. Thus, any fission products that leaked into the primary coolant through fractures in the cladding of the reactor fuel rods would have been removed by the demineralizer and processed by the radioactive waste control system (Brown et al., 1967). The exposure of support personnel to radiation from packages containing radioactive materials is presumed to have occurred during any DF year.

\subsubsection{Movement of Radioisotope Thermal Generators}

Support personnel could have been exposed to external x-ray radiation consisting of bremsstrahlung radiation produced by the radioactive sources in Radioisotope Thermal Generators (RTGs) stored at the station awaiting transport. RTGs are portable electrical power units that use the decay heat from radioactive materials as their power source. They were not 
used at McMurdo Station, but were shipped to McMurdo Station during transit to other locations and were temporarily stored at the NPP. The RTGs are assumed to have been shipped in accordance with IAEA requirements and their radiation levels were limited to external exposure rates acceptable for the labeling of the package (Foster and Jones, 1982). All support personnel

are assumed to have been exposed to this radiation source. The exposure of support personnel to radiation from RTGs is presumed to have occurred during any DF year.

\subsubsection{Loading of Radioactive Waste}

Support personnel could have been exposed to external gamma radiation from shipments of radioactive waste or bulk soil contaminated with radioactive materials as part of their duties. Self-reading (self-indicating) dosimeters were issued to McMurdo Station support personnel and ship crews during the loading of some of the shipments of radioactive waste or large quantities of soil contaminated with radioactive materials (NNPU, 1976 and 1977a) Self-reading dosimeter records are available for one year and are assumed to reflect the external radiation exposures received by support personnel during the radioactive waste loading operations. The loading of the radioactive waste is presumed to have occurred during any DF year. The loading of bulk contaminated soil would have occurred during the decommissioning years from DF 77 to 79 .

\subsubsection{Spilled or Residual Contaminated Soil}

Support personnel could have been exposed to residual radiation from bulk contaminated soil left over after ship loading or spilled onto the roads leading to the ship loading area (NNPU, 1977a). Support personnel would have been exposed to higher levels of radiation from spilled soil during loading and shipping operations than after spill cleanup had occurred. These exposures would have occurred during DF 75, 76, 77, 78, and 79.

\subsection{Internal Radiation}

The support personnel at McMurdo Station worked and lived outside the NPP and could have been exposed to internal radiation resulting from the inhalation or ingestion of radioactive materials released outside the plant. The following sources of potential exposure to internal radiation are considered for support personnel at McMurdo Station:

1) Inhalation of airborne radioactive materials from the emissions of fission and activation products released through the NPP stack or worldwide fallout.

2) Inhalation of suspended soil contaminated with radioactive materials during the decommissioning of the NPP; suspended soil spilled during transport to the ship loading area and ship loading and suspended residual soil contamination.

3) Ingestion of tritium in drinking water.

4) Ingestion of radioactive materials in drinking water other than tritium.

5) Incidental ingestion of contaminated soil and dust during decommissioning. 


\subsubsection{Inhalation of Airborne Radioactive Materials from Emissions Released through the NPP Stack and Worldwide Fallout}

Support personnel could have inhaled airborne radioactive materials to include gases and aerosols released from the main stack of the NPP and worldwide fallout from past and ongoing atmospheric nuclear testing. The inhalation could have occurred both during duty and non-duty times in areas outside of the NPP facility (Foster and Jones, 1982). All support personnel are assumed to have inhaled airborne radioactive materials in effluent from the NPP during the operation phase (DF 62 to 72) and airborne worldwide fallout during any DF year.

\subsubsection{Inhalation of Suspended Soil Contaminated with Radioactive Materials}

Support personnel could have inhaled suspended soil contaminated with radioactive materials during the excavation and removal of backfill surrounding equipment and building installations at the NPP. Suspended soil contaminated with radioactive materials could have drifted beyond the NPP boundary and been inhaled by support personnel. Support personnel are assumed to have been exposed to suspended contaminated soil during DF 75 to 79.

Support personnel could have been exposed to suspended contaminated soil during the decontamination of the effluent release areas of the NPP. Support personnel who participated in the decontamination of the effluent release areas adjacent to the NPP would have been exposed to the suspended residual soil contaminated with radioactive materials for their entire time at McMurdo Station. Support personnel are assumed to have been exposed to suspended contaminated soil during decontamination of the effluent release areas adjacent to the NPP during DF 77 to 79.

Support personnel could have inhaled suspended soil contaminated with radioactive materials that was spilled during the transport of bulk soil to the ship loading areas or during ship loading. The support personnel are assumed to have assisted in the bulk soil loading. In addition, support personnel could have inhaled suspended residual contaminated soil after the spilled bulk soil contaminated with radioactive materials was cleaned up. Support personnel could have been exposed to suspended spilled contaminated soil and residual spilled soil during DF 75 to 79.

\subsubsection{Ingestion of Tritium in Drinking Water}

Support personnel could have ingested tritium in the drinking water at McMurdo Station. Measurements in drinking water showed low levels of tritium that possibly could have come from the water effluent released from the NPP or originated from worldwide fallout, which then entered the water supply sources. Support personnel are assumed to have ingested tritium in drinking water during any DF year. (Foster and Jones, 1982)

\subsubsection{Ingestion of Radioactive Materials in Drinking Water other than Tritium}

Support personnel could have ingested radioactive materials other than tritium in the drinking water at McMurdo Station. The drinking water could have contained long-lived beta activity other than tritium released from the NPP through water or gas emissions that found its way to the source of drinking water. Radioactive contamination in drinking water could also be 
from naturally occurring radioactivity and fallout from atmospheric testing of nuclear weapons (Foster and Jones, 1982). Support personnel are assumed to have ingested radioactive material in drinking water during any DF year.

\subsubsection{Incidental Ingestion of Soil and Dust Contaminated with Radioactive Materials}

Support personnel at McMurdo Station could have incidentally ingested soil and dust contaminated with radioactive materials. The soil could have been from spills in the ship loading area or on the roads leading to the ship docks (NNPU, 1976). Support personnel are assumed to have incidentally ingested contaminated soil and dust during DF 77 to 79. 


\section{4. \\ Radiation Monitoring}

During the operation and decommissioning of the McMurdo Station NPP, measurements were made to characterize radiation exposures of reactor crew members as well as for environmental monitoring. This includes external radiation levels inside and in areas adjacent to the NPP facility, and in the effluent discharge area. Measurements were also made of radioactive materials concentrations in emissions from the plant stack. Furthermore, measurements were made to monitor air activity concentrations near the living quarters of McMurdo Station personnel and water activity concentrations in the drinking water. This section will review the available data that can be used to estimate radiation doses for support personnel.

\subsection{Exposure Records of Reactor Personnel}

Film badge dosimetry records covering the periods when reactor crew members were assigned to the NPP have been located for individuals who served during DF 62, 63, 64, 65, 72 and 73. Partial dosimetry results or results for one of the two calendar years of a winter-over tour have been located for some reactor crew members for DF 66, 67, 68, 69, 70, and 71. Partial austral summer film badge results are available for DF 74. For all other austral summers during decommissioning activities, sufficient film badge results were not available to perform a statistical analysis because reactor crew personnel were only present at McMurdo Station during the austral summer. (NDC, 1962-1979)

The compiled gamma radiation dosimetry records for reactor crew members for DF years for which dosimetry results were located are summarized in Table 5. For the years where complete dosimetry results are available, the doses varied based on the Navy occupational ratings of the individuals wearing the film badges (ASF, 1962-1979; NDC, 1962-1979). The highest film badge results were typically those for utilitiesmen and construction electricians. The lowest film badge results were typically for those storekeepers or logistics specialists.

Table 5 does not include neutron doses because they were not reported for all DF years for which complete gamma radiation results are available. The neutron doses are considered to represent less than $5 \%$ of the total gamma doses received by reactor crew members (Johnson, 1971). The neutron doses for support personnel are considered to be insignificant and not included in the dose assessment.

Internal monitoring records have been located for some of the reactor crew members. The internal monitoring consisted of whole-body counting of returning crew members at the National Naval Medical Center in Bethesda, Maryland (now called Walter Reed National Military Medical Center). Whole-body counting consists of using an array of photon detectors to measure the gamma emitters that have been deposited inside one's body (Cember, 1983). The internal monitoring measurements consisted of estimates of the amount of Cs-137, Mn-54, and Co-60 in the body. The U.S. Navy compared the results, at the time of measurement, to the 
National Bureau of Standards Handbook 69 (U.S. Navy 1972b; NBS, 1959) values for permissible body burdens to determine if federal guidance had been exceeded. For the whole-body count data available for review, no results exceeded the maximum permissible body burdens (U.S. Navy, 1972b).

Self-reading dosimeters were used to monitor short-term exposures to reactor crew members in the NPP during the operation of the reactor. They were worn in addition to a reactor crew member's film badge, and were used to assist in assessing compliance with the Type II HPSC Reports of radiation doses in excess of 0.350 rem $(3.5 \mathrm{mSv})$ in seven consecutive days as well as to ensure compliance with radiation work permits that were used to document work activities in areas of high radiation levels (Foster and Jones, 1982; Martin Company, 1964).

Self-reading dosimeters were also used to monitor the doses of support personnel who assisted in the transport and ship loading of radioactive waste and contaminated soil. The selfreading dosimeters were issued for the days when ships were being loaded with radioactive waste or contaminated soil (NNPU, 1977a). Dosimeter results were located for two dates and are shown in Table 6. The self-reading dosimeter results were for DF 76, the year during which a large amount of radioactive waste-including the contaminated pressure vessel-was returned to the U.S. (Foster and Jones, 1982).

\subsection{External Radiation Measurements}

Measurements of dose rates inside the NPP and the radioactive waste storage areas during operational and decommissioning years have not been located. However, it is well documented that exposure rate and other environmental monitoring measurements were made inside the NPP (Foster and Jones, 1982; Martin Company, 1964). Discussions with veterans indicated that gamma and neutron radiation survey instruments were available for use (Fegley, 2012). A review of the NNPU Health Physics Operations Logs indicated that external radiation measurements were made to include dose rates and contamination activity measurements. However, only a small number of records was available for review (NNPU, 1969). Currently, insufficient external dose/exposure rate data is available to be able to perform detailed dose assessments for support personnel using those types of measurements.

During DF 78, 43 environmental thermoluminescent dosimeters (TLD) were exposed for 85 days at NPP on-site locations and for 76 days in off-site locations. The TLDs in the on-site locations measured radiation doses between $0.005 \mathrm{rad}(0.05 \mathrm{mGy})$ to $0.048 \mathrm{rad}(0.48 \mathrm{mG})$. The TLDs in the off-site locations measured radiation levels of $0.004 \mathrm{rad}(0.04 \mathrm{mGy})$ to $0.032 \mathrm{rad}$ (0.32 mGy).

External radiation measurements were made in the effluent discharge areas during the decommissioning of the NPP from 1974 to 1979. Records of some measurements have been located (NNPU, 1976; NNPU 1977b). Radiation level measurements were made to locate the areas with high levels of soil contamination during the initial phase of the decommissioning. Additional measurements were made after the removal of contaminated soil during subsequent phases of decommissioning. The results of the radiation level rate measurements were not suitable for use in the dose reconstruction because the measurements were not available for all years, the measurements were reported in units of counts per minute, and they were spot measurements. 
Table 5. Compiled dosimetry records for reactor crew members

\begin{tabular}{|c|c|c|c|c|c|}
\hline DF & No. & $\underset{(\operatorname{rem}(\mathrm{mSv}))}{\operatorname{Minimum}}$ & $\begin{array}{c}\text { Maximum } \\
(\operatorname{rem}(\mathrm{mSv}))\end{array}$ & $\begin{array}{c}\text { Mean } \\
(\operatorname{rem}(\mathrm{mSv}))\end{array}$ & Remarks \\
\hline 62 & 13 & 0.137 (1.37) & $0.716(7.16)$ & $0.316(3.16)$ & $\begin{array}{l}\text { Less than full year of } \\
\text { operation }\end{array}$ \\
\hline 63 & 21 & $0.160(1.60)$ & 2.878 (28.8) & $0.890(8.90)$ & \\
\hline 63 Summer & 6 & $0.220(2.20)$ & $0.835(8.35)$ & 0.496 (4.96) & \\
\hline 64 & 17 & $0.060(0.60)$ & 1.965 (19.7) & $0.860(8.60)$ & \\
\hline 64 Summer & 11 & 0.247 (2.47) & 1.915 (19.2) & $0.946(9.46)$ & \\
\hline 65 & 16 & $0.572(5.72)$ & 3.968 (39.7) & $2.048(20.5)$ & \\
\hline 65 Summer & 10 & $0.854(8.54)$ & 3.499 (35.0) & $1.863(1.86)$ & \\
\hline 66 & 23 & $0.060(0.60)$ & $3.814(38.1)$ & $1.696(17.0)$ & CY 66 only $^{*}$ \\
\hline 66 Summer & 10 & $0.067(0.67)$ & $2.705(27.1)$ & $0.949(9.49)$ & CY 66 only $^{*}$ \\
\hline 67 & 21 & $0.096(0.96)$ & $6.145(61.5)$ & $3.624(36.2)$ & CY 67 only $^{*}$ \\
\hline 67 Summer & 11 & $0.067(0.67)$ & 3.187 (31.9) & $1.334(13.3)$ & CY 67 only $^{*}$ \\
\hline 68 & 20 & 0.168 (1.68) & $3.072(30.7)$ & 1.409 (14.1) & $\left.\right|_{\text {CY } 68 \text { only }^{*}}$ \\
\hline 68 Summer & 10 & $0.285(2.85)$ & $3.057(30.6)$ & $1.702(17.0)$ & CY 68 only $^{*}$ \\
\hline 69 & 21 & $0.110(1.10)$ & $7.551(75.5)$ & $3.421(34.2)$ & CY 69 only $^{*}$ \\
\hline 69 Summer & 4 & $1.635(16.4)$ & $3.620(36.2)$ & $2.836(28.4)$ & CY 69 only $^{*}$ \\
\hline 70 & 22 & $4.602(46)$ & $10.800(108)$ & $7.913(79.1)$ & CY 70 only $^{*}$ \\
\hline 70 Summer & 5 & $0.965(9.65)$ & $5.895(59.0)$ & $2.817(28.2)$ & CY 70 only $^{*}$ \\
\hline 71 & 18 & $0.120(1.20)$ & $2.840(28.4)$ & $1.681(16.8)$ & CY 70 only $^{*}$ \\
\hline 71 Summer & 10 & $0.087(0.87)$ & $3.804(38.0)$ & $1.912(19.1)$ & CY 70 only $^{*}$ \\
\hline 72 & 22 & $0.185(1.85)$ & $9.955(99.6)$ & $7.034(70.3)$ & $\begin{array}{l}\text { Reactor shut down in Oct } \\
1972\end{array}$ \\
\hline 72 Summer & 4 & $0.564(5.64)$ & $1.879(18.8)$ & $1.316(13.2)$ & Reactor in standby mode \\
\hline 73 & 9 & $0.693(6.93)$ & $2.564(25.6)$ & $1.502(15.0)$ & Reactor not operational \\
\hline 73 Summer & 18 & $0.024(0.24)$ & $5.766(57.7)$ & $2.295(22.9)$ & Reactor not operational \\
\hline 74 Summer & 7 & $0.716(7.16)$ & $4.905(49.1)$ & $2.663(26.6)$ & Reactor not operational \\
\hline
\end{tabular}

* Dosimetry located for one of two calendar years that comprised a DF tour (see Section 5 for discussion of how partial dosimetry records are used in the dose assessment for support personnel).

Exposure rate measurements in the vicinity of radioactive waste packages were made. Records of 11 radioactive waste shipments made in 1970 through 1972 have been located. These records include dose rates at one meter from outside surface of the radioactive waste packages. The average dose rate at one meter of the radioactive waste packages is $0.008 \mathrm{rad} \mathrm{h}^{-1}$ $\left(0.08 \mathrm{mGy} \mathrm{h}^{-1}\right)$. Also, records for 21 shipments of RTGs were located. The average dose rate at one meter from the outside surface of the RTG packages is $0.003 \mathrm{rad} \mathrm{h}^{-1}\left(0.03 \mathrm{mGy} \mathrm{h}{ }^{-1}\right)$. (NNPUD, 1972) 
Table 6. Self-reading dosimeter results for ship loading operations

\begin{tabular}{|c|c|c|c|c|c|}
\hline DF & Date & $\begin{array}{c}\text { Number of } \\
\text { Dosimeters } \\
\text { issued }\end{array}$ & $\begin{array}{c}\text { Minimum } \\
\text { Self-Reading } \\
\text { Doses }\end{array}$ & $\begin{array}{c}\text { Maximum } \\
\text { Self-Reading } \\
\text { Doses }\end{array}$ & $\begin{array}{c}\text { Average of all } \\
\text { Self-Reading } \\
\text { Doses }\end{array}$ \\
\hline 76 & Feb 8, 76 & 26 & $\begin{array}{c}0.001 \mathrm{rem} \\
(0.01 \mathrm{mSv})\end{array}$ & $\begin{array}{c}0.036 \mathrm{rem} \\
(0.36 \mathrm{mSv})\end{array}$ & $\begin{array}{c}0.012 \mathrm{rem} \\
(0.12 \mathrm{mSv})\end{array}$ \\
\hline 76 & Feb 9, 76 & 35 & $\begin{array}{c}0.001 \mathrm{rem} \\
(0.01 \mathrm{mSv})\end{array}$ & $\begin{array}{c}0.084 \mathrm{rem} \\
(0.84 \mathrm{mSv})\end{array}$ & $\begin{array}{c}0.023 \mathrm{rem} \\
(0.23 \mathrm{mSv})\end{array}$ \\
\hline
\end{tabular}

\subsection{Airborne Activity Concentrations}

The monthly averages of the continuous 24-hour air sampling results are available from January 1961 before the arrival and installation of the reactor (Busdiecker and Maxwell, 1964) until December 1972, after the shutdown of the reactor. The air samples were taken at Building 63 in the main building area of McMurdo Station. The air samples were collected for 24 hours each day and are assumed to represent the average air concentration inhaled by all individuals at McMurdo Station, including support personnel. The air sample results are reported as gross long-lived beta activity in the air. The air samples are assumed to contain I-131, Cs-137, Ru-106, Zr-95, and Ce-144 (Foster and Jones, 1982). Also, the air sample results are assumed to include natural background activity (Foster and Jones, 1982; NNPU, 1973b). The samples were analyzed using a Geiger-Mueller detection system (Martin Company, 1964). The monthly averages are shown in Table 7 and Figure 7.

Some of the variations in monthly measured air activity can be attributed to atmospheric nuclear testing by several countries to include atmospheric tests in 1961-1962, 1966, 1968, and 1970. Some of the variation in monthly measured air activities have also been attributed to seasonal mixing of the stratosphere and troposphere as seen in 1965 and early 1970 (Foster and Jones, 1982). The periods marked with "FO" in Figure 7 are associated with worldwide fallout while "AM" designates the periods of increased measured activity due mainly to atmospheric mixing. The periods from August 1965 to September 1966, March 1968 to February 1969, and June 1969 to March 1970 are considered the months when the measured long-lived beta activity in air samples were least affected by worldwide fallout.

Air sampling data collected during the removal of contaminated soil from the effluent discharge area are available for November and December 1975, January 1976, and January 1977. The air samples were taken in the area where contaminated soil was removed near the NPP or in the area of bulk soil ship loading area. For the dose calculations, the air samples are assumed to measure airborne Cs-137. The results of the air samples during soil decontamination are given in Table 8. (NNPU, 1976; NNPU, 1977b) 
Table 7. Monthly average of long-lived beta activity for 24-hour air samples ${ }^{*}\left(\mathrm{~Bq} \mathrm{~L}^{-1}\right)$

\begin{tabular}{|c|c|c|c|c|c|c|c|c|c|c|c|c|}
\hline Year & Jan & Feb & Mar & Apr & May & June & Jul & Aug & Sep & Oct & Nov & Dec \\
\hline 1961 & 2.22 & 1.85 & 0.74 & 0.74 & 0.74 & 0.37 & 0.74 & 0.37 & 0.74 & 0.74 & 0.74 & 0.74 \\
\hline 1962 & 0.74 & 0.74 & 1.11 & 0.74 & 0.74 & 1.11 & 2.59 & 1.85 & 2.59 & 2.96 & 3.70 & 1.85 \\
\hline 1963 & 4.81 & 7.40 & 5.92 & 5.55 & 4.07 & 2.59 & 2.59 & 2.59 & 2.22 & 1.48 & 2.22 & 2.96 \\
\hline 1964 & 3.33 & 3.33 & 2.59 & 2.59 & 2.96 & 2.96 & 3.33 & 2.22 & 2.96 & 3.70 & 4.07 & 4.44 \\
\hline 1965 & 4.07 & 5.55 & 3.70 & 2.59 & 2.96 & 2.96 & 2.22 & {$[1.85$} & 2.22 & 1.48 & 0.74 & 1.11 \\
\hline 1966 & 1.11 & 1.11 & 1.11 & 0.74 & 0.74 & 0.74 & 1.11 & 1.48 & 1.48 & 2.22 & 4.07 & 4.44 \\
\hline 1967 & 6.29 & 5.92 & 4.81 & 3.33 & 2.96 & 2.96 & 2.96 & 3.70 & 4.07 & 4.07 & 3.33 & 2.59 \\
\hline 1968 & 2.22 & 1.85 & {$[1.48$} & 1.48 & 1.48 & 1.48 & 1.11 & 1.11 & 1.48 & 1.48 & 1.85 & 1.48 \\
\hline 1969 & 1.85 & $1.48]$ & 4.81 & 4.81 & 2.59 & {$[1.11$} & 1.11 & 1.85 & 1.11 & 1.11 & 1.48 & 0.74 \\
\hline 1970 & 0.74 & 2.59 & $1.11]$ & 2.22 & 7.03 & 6.29 & 1.85 & 1.48 & 2.59 & 1.85 & 2.22 & 6.66 \\
\hline 1971 & 0.74 & 4.07 & 1.85 & 11.84 & 8.88 & 4.07 & 2.96 & 2.96 & 3.70 & 7.40 & 5.18 & 5.18 \\
\hline 1972 & 5.92 & 5.18 & 6.29 & 2.96 & 3.33 & 1.85 & 2.22 & 1.48 & 2.22 & 1.11 & 0.74 & 1.85 \\
\hline
\end{tabular}

*The highlighted cells correspond to the periods that were least affected by worldwide fallout and most likely representing mostly emissions from the NPP. The start and stop of each period is indicated with square brackets.

Table 8. Air samples taken during removal and loading of bulk contaminated soil

\begin{tabular}{|c|l|c|c|}
\hline DF & \multicolumn{1}{|c|}{ Date (Location) } & Location & $\begin{array}{c}\text { Activity } \\
\mu \mathrm{Ci} \mathrm{mL}\left(\mathrm{Bq} \mathrm{mL}^{-1}\right)\end{array}$ \\
\hline 76 & November 25, 1975 & NPP & $2 \times 10^{-11}\left(7 \times 10^{-7}\right)$ \\
\hline 76 & December 1, 1975 & NPP & $4 \times 10^{-12}\left(1 \times 10^{-7}\right)$ \\
\hline 76 & January 31, 1976 & NPP & $9 \times 10^{-13}\left(4 \times 10^{-8}\right)$ \\
\hline 77 & January 30, 1977 & Ship loading area & $9 \times 10^{-13}\left(4 \times 10^{-8}\right)$ \\
\hline
\end{tabular}




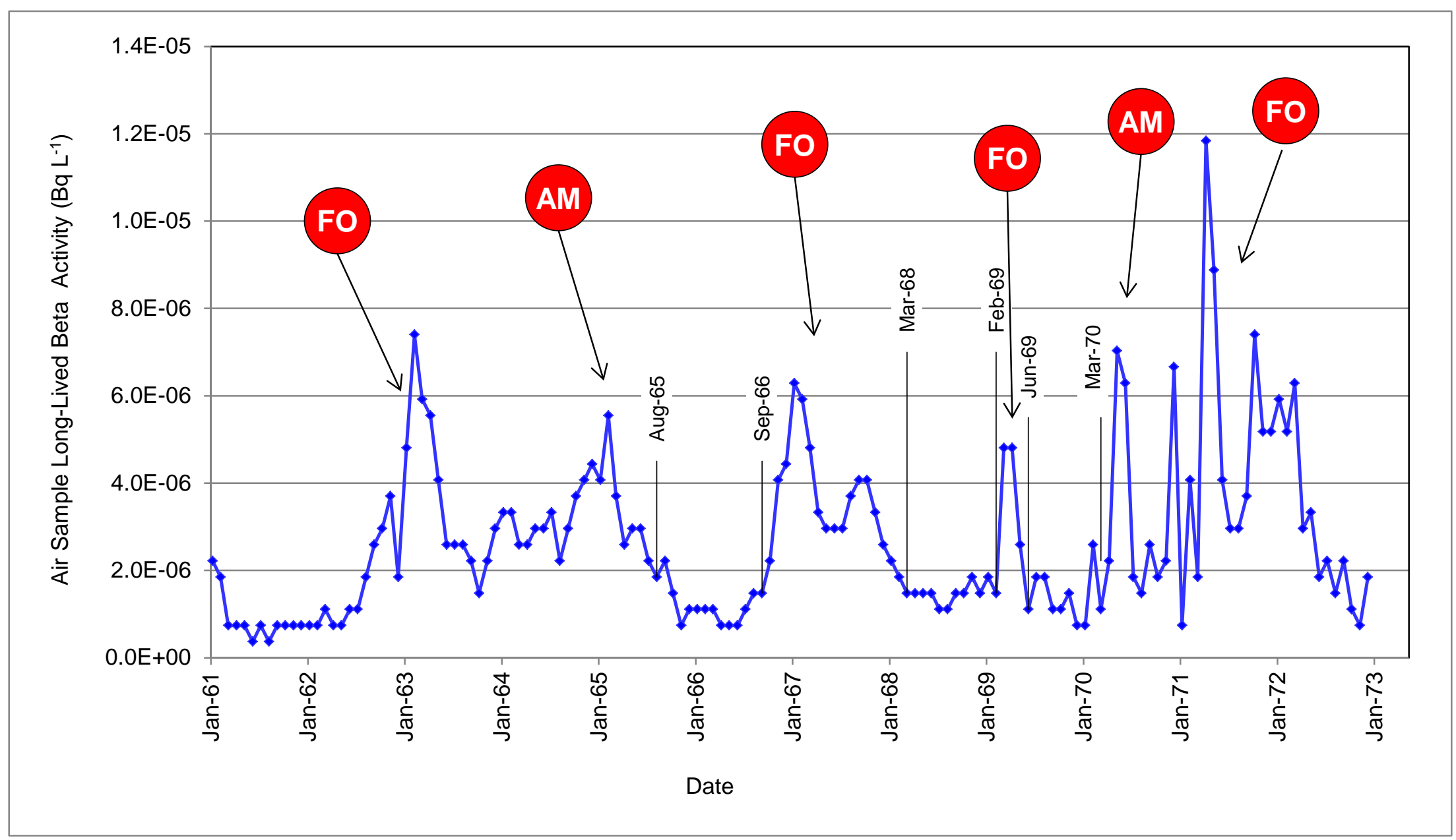

Figure 7. Monthly average long-lived beta activity in 24-hour air samples FO = fallout $A M=$ atmospheric mixing 


\subsection{Radioactivity Concentrations in Water}

Monthly drinking water samples were collected at the galley. The water samples were analyzed by evaporation of the water on a planchet followed by measurement using a shielded Geiger-Mueller detector capable of detecting gross beta-gamma activity (Martin Company, 1964). The activity concentration results are available from January 1961 to December 1972. These samples were analyzed for gross long-lived beta activity. The NNPU raised concerns about some abnormally high levels reported during 1969. The NNPU concluded that the unusually higher concentration results were due to inadequate measurement techniques (Foster and Jones, 1982). However, for this assessment, the reported results are used because they result in higher, more conservative dose estimates. In addition, the results are assumed to include background (Foster and Jones, 1982; NNPU, 1973a).

The results of monthly drinking water sampling are shown in Table 9 and Figure 8. Monthly drinking water sample data was not available for April and September, 1961 and for July, 1962. To account for the possibility of residual radioactive materials in the drinking water after the end of the drinking water sampling program, the December 1972 result is used for all months from January 1973 to March 1979 for the dose assessment.

Table 9. Long-lived beta activity in monthly drinking water samples $\left(\mathrm{Bq} \mathrm{L}^{-1}\right)$

\begin{tabular}{|c|c|c|c|c|c|c|c|c|c|c|c|c|}
\hline Year & Jan & Feb & Mar & Apr & May & June & July & Aug & Sep & Oct & Nov & Dec \\
\hline 1961 & 0.04 & 0.44 & 0.15 & ND $^{*}$ & 0.15 & 0.15 & 0.11 & 0.26 & ND & 0.11 & 0.22 & 0.04 \\
\hline 1962 & 0.02 & 1.30 & 0.22 & 0.19 & 0.22 & 0.26 & ND & 0.48 & 0.26 & 0.48 & 0.30 & 0.26 \\
\hline 1963 & 0.93 & 0.15 & 0.44 & 0.95 & 0.26 & 0.59 & 0.59 & 0.33 & 0.22 & 0.09 & 0.31 & 0.17 \\
\hline 1964 & 0.71 & 0.67 & 0.45 & 0.47 & 0.32 & 0.30 & 0.45 & 0.80 & 0.55 & 0.70 & 0.66 & 0.64 \\
\hline 1965 & 0.68 & 1.09 & 0.81 & 1.03 & 1.15 & 0.26 & 0.68 & 0.64 & 0.33 & 0.45 & 0.65 & 0.67 \\
\hline 1966 & 0.43 & 0.21 & 0.42 & 0.40 & 0.28 & 0.21 & 0.42 & 0.24 & 0.26 & 0.06 & 0.00 & 0.00 \\
\hline 1967 & 0.00 & 0.00 & 0.30 & 0.28 & 0.28 & 0.23 & 0.23 & 0.17 & 2.18 & 0.19 & 0.63 & 0.19 \\
\hline 1968 & 0.36 & 0.08 & 0.05 & 0.05 & 0.05 & 0.05 & 0.05 & 0.07 & 0.04 & 0.41 & 0.27 & 0.14 \\
\hline 1969 & 0.43 & 1.58 & 1.20 & 1.20 & 2.06 & 4.18 & 0.44 & 1.55 & 0.47 & 0.46 & 0.46 & 0.70 \\
\hline 1970 & 1.96 & 0.28 & 0.15 & 0.16 & 0.31 & 0.10 & 0.17 & 0.29 & 0.10 & 0.64 & 0.16 & 0.15 \\
\hline 1971 & 0.24 & 0.17 & 0.15 & 0.19 & 0.20 & 0.22 & 0.23 & 0.23 & 0.23 & 0.22 & 0.22 & 0.19 \\
\hline 1972 & 0.36 & 0.14 & 0.14 & 0.29 & 0.22 & 0.19 & 1.45 & 0.38 & 1.48 & 0.27 & 0.21 & 0.31 \\
\hline
\end{tabular}

* Results were not available for the months marked with ND. For the dose assessment calculation, the higher value from the two adjacent months was assigned as the activity for those months. 


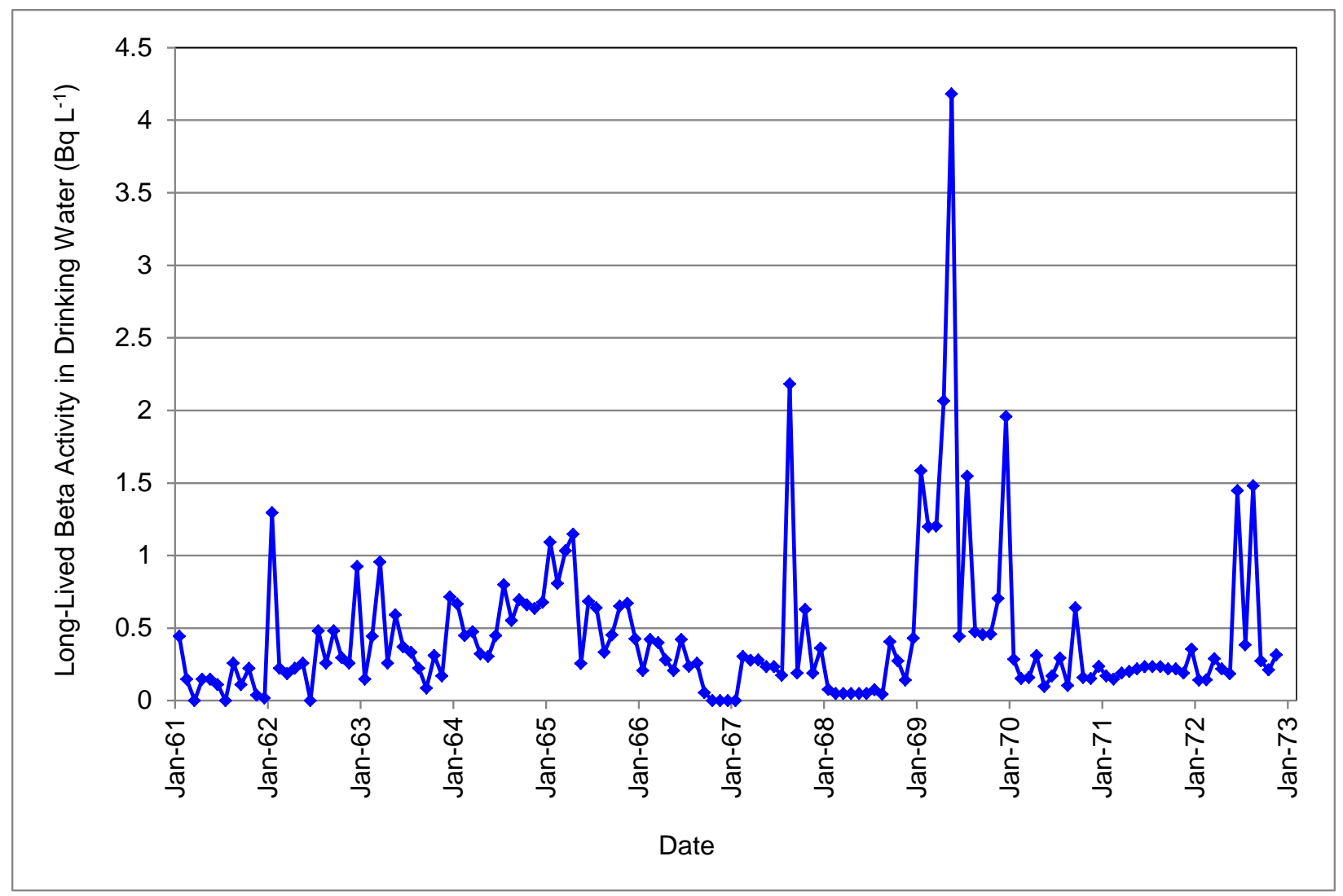

Figure 8. Long-lived beta activity in monthly drinking water samples

Weekly samples of the distillate (drinking water) from the water distillation plant were taken and analyzed for tritium starting in March 1967 and ending in November 1972. The results of the monthly average activity of the weekly tritium drinking water monitoring are shown in Table 10 and Figure 9. Results are not available for April 1967, December 1968, December 1969, April 1970, June 1970, and December 1972. The higher of the preceding and following month's results are used in the dose assessment as an estimate for the missing months (Foster and Jones, 1982; NNPU, 1973a). The value of $16,000 \mathrm{~Bq} \mathrm{~L}^{-1}$ for the first month tritium was measured, which was followed by a month with no measurements, appears to be an outlier possibly due to first implementation of a new analysis procedure. This value was still used in the dose calculation for the months of March and April 1967.

Additionally, weekly seawater samples were analyzed for tritium starting in March 1967 and ending in November 1972 (Foster and Jones, 1982 and NNPU, 1973). The tritium in seawater results were not used in the dose assessment since the tritium monitoring of the drinking water from the water distillation plant is used to estimate tritium ingestion doses. 
Table 10. Monthly average tritium activity in drinking water samples $\left(\mathrm{Bq} \mathrm{L}^{-1}\right)$

\begin{tabular}{|c|c|c|c|c|c|c|c|c|c|c|c|c|}
\hline Year & Jan & Feb & Mar & Apr & May & Jun & Jul & Aug & Sep & Oct & Nov & Dec \\
\hline 1967 & & & 16,000 & ND $^{*}$ & 330 & 23 & 2,400 & 200 & 120 & 70 & 480 & 2,800 \\
\hline 1968 & 1,500 & 340 & 1,800 & 600 & 300 & 300 & 200 & 170 & 170 & 190 & 3,000 & ND \\
\hline 1969 & 180 & 160 & 180 & 730 & 160 & 180 & 180 & ND & 230 & 220 & 500 & 640 \\
\hline 1970 & 250 & 440 & 1,000 & ND & 300 & ND & 260 & 220 & 260 & 210 & 370 & 100 \\
\hline 1971 & 80 & 90 & 80 & 150 & 40 & 40 & 40 & 40 & 40 & 40 & 150 & 50 \\
\hline 1972 & 70 & 100 & 130 & 140 & 150 & 100 & 150 & 280 & 120 & 120 & 140 & \\
\hline
\end{tabular}

* Results were not available for the months marked with ND. For the dose assessment calculation, the higher value from the two adjacent months was assigned as the activity for those months.

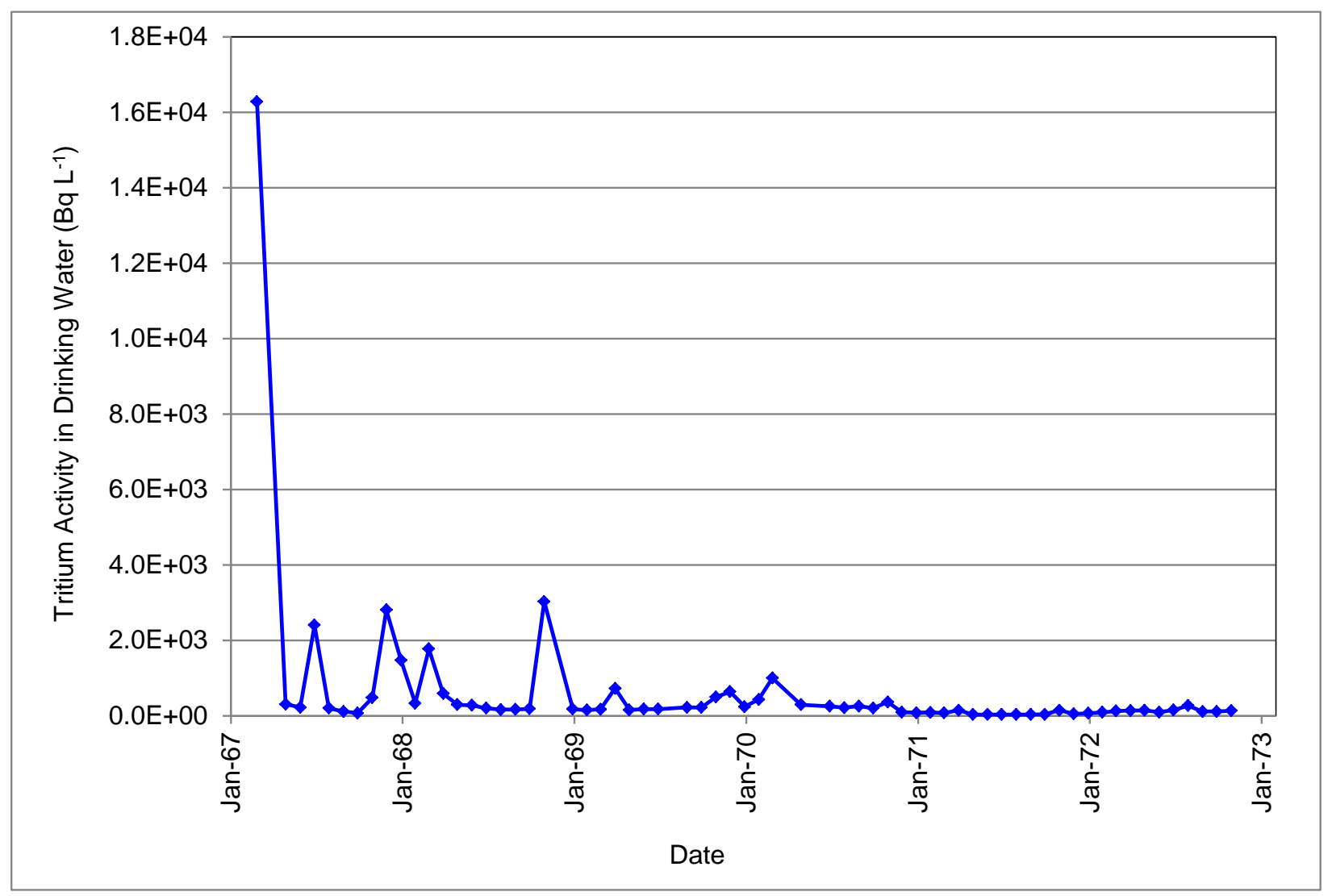

Figure 9. Monthly average tritium activity in drinking water samples

\subsection{Radioactivity Concentrations in Soil}

Contaminated soil was analyzed during the decommissioning of the NPP. In 1978, soil and rock samples were analyzed by the U.S. Navy Civil Engineering Laboratory, the Department of Energy, and the NUS Corporation for radioactive contamination. Samples of crushed rock 
were taken in December 1977 and January 1978 from the crushed rock and soil piles that were awaiting transport as part of the $3,500 \mathrm{~m}^{-3}$ of contaminated soil shipped to the United States. The results for Cs 137 contamination ranged from a low of less than $1 \mathrm{pCi} \mathrm{g}^{-1}\left(0.04 \mathrm{~Bq} \mathrm{~g}^{-1}\right)$ to a maximum of $310 \mathrm{pCi} \mathrm{g}^{-1}\left(12 \mathrm{~Bq} \mathrm{~g}^{-1}\right)$. In addition, analyses for Tl-208, Cs-134, and Bi-214 were performed and showed detectable quantities, but these concentrations were usually an order of magnitude or more lower than those of Cs-137. (Jordan, 1978)

A final report summarizes the residual contamination in the soil and rock in the areas around the NPP facility during DF 78 (Jentz, 1978). During the residual contamination survey, 121 soil samples were collected and analyzed. The Cs-137 contamination in the soil and rock samples ranged from a low of less than $1 \mathrm{pCi} \mathrm{g}^{-1}\left(0.04 \mathrm{~Bq} \mathrm{~g}^{-1}\right)$ to a maximum of $400 \mathrm{pCi} \mathrm{g}^{-1}$ $\left(15 \mathrm{~Bq} \mathrm{~g}^{-1}\right)$. Analysis was also made for Tl-208, Cs-134, Bi-214, Co-60, and Sr-90. The soil samples generally contained detectable amounts of Cs-134, Co-60, and Sr-90 but the concentrations were usually an order of magnitude or more lower than that of Cs-137. The total measured activity for all byproduct radioactive material (fission products) in the soil samples was less than $500 \mathrm{pCi} \mathrm{g}^{-1}$ (19 Bq) (Jentz, 1978).

\subsection{Removable Radioactivity on Surfaces}

Weekly smear tests for gross beta contamination were made at the galley and crew member living quarters (Foster and Jones, 1982). The only reported smear test data available for review was for 1972. The available data reported no detectable levels of removable contamination for 1972 (NNPU, 1973a).

\subsection{Radiation Levels of Radioactive Waste Shipments}

Documentation of some radioactive waste shipments was located for 11 shipments from DF 70 through DF 72. Records of 21 shipments of RTGs for DF 70 to 72 were also located. The average dose rate at one meter from the outside surface of the container for the 11 shipments of radioactive waste was $0.008 \mathrm{R} \mathrm{h}^{-1}\left(0.08 \mathrm{mGy} \mathrm{h}^{-1}\right)$. The average dose rate at one meter from the outside surface of the container for the 21 RTG shipments was $0.003 \mathrm{R} \mathrm{h}^{-1}\left(0.03 \mathrm{mGy} \mathrm{h}{ }^{-1}\right)$.

(NNPUD, 1972) 


\section{5. \\ Dose Assessment Methodology and Assumptions for Support Personnel}

When individuals are not monitored for radiation through the use of personal or cohort (a group with common characteristics) measurements, the external and internal radiation doses are estimated using dose reconstruction methods. The methods include the use of high-sided estimates of parameters affecting the dose to personnel along with uncertainty factors that lead to upper-bound doses. Such reconstructed dose estimates should be considered generic upperbound doses for support personnel whose reported activities and scenarios of exposures fall within those that are assumed in the dose assessment described in this report. This section describes the methods used for assessing the dose for each external and internal exposure pathway identified in Section 3. The parameter values selected for the calculation of doses and uncertainty factors are also included. The results of the radiation dose assessment for support personnel are presented and discussed in Section 6.

\subsection{External Dose Methods and Assumptions}

For the support personnel who were located at the McMurdo Station during the installation, operation and decommissioning of the NPP, the following potential exposure scenarios and pathways are considered in the assessment of external radiation exposures:

1) Exposure to radioactive sources inside the reactor facility while either touring or visiting the NPP.

2) Exposure to radioactive sources inside the reactor while near the fence of the NPP, such as when driving, hiking, or walking.

3) Exposure to airborne radioactivity by immersion in indoor and outdoor air containing radioactive noble gases released from the NPP during operations.

4) Exposure to radioactive packages transported to and from the ship loading area outside the NPP facility.

5) Exposure to radiation sources due to the movement of RTGs.

6) Exposure to radioactive materials due to loading of radioactive waste onto ships.

7) Exposure to soil contaminated with radioactive materials that was spilled on the ground, roads, and ship loading areas. 


\subsubsection{Touring or Visiting the NPP}

To estimate the external dose for support personnel who may have toured or visited the NPP facility, the film badge results of the winter-over reactor crew members are used (NDC, 1962-1979). These film badge results are used since they are the only data available to estimate the average external dose rates inside the NPP facility for all years of reactor operation. This method of estimating an average dose rate inside the NPP for each DF year is very conservative since the reactor crew results include the larger doses received by some reactor crew members who performed activities inside the primary building and in areas below ground level, where visitors would not have gone. The parameter values and assumptions shown in Table 11 are used to estimate the average dose rates inside the NPP. For the years where dosimetry data were not available, the average dose rates are estimated based on the mean dose rate values calculated for years where dosimetry data exist even though the average dose rates will be higher than actual dose rates due to the change in operations. The average dose rates are calculated using the methods presented in Appendix B.

The parameter values and assumptions shown in Table 12 are used to estimate the external gamma dose for support personnel touring or visiting the NPP. Table 13 shows the estimated average dose rate for each DF year and the basis for the estimate. For the years where the only major source of external radiation dose at the NPP was exposure to residual radiation in bulk contaminated rock and soil, the average dose rate was based on TLD measurements made during a radiological survey in the austral summer of DF 78. The dose estimates for support personnel touring or visiting the NPP are calculated using the methods presented in Appendix B.

The external dose for touring or visiting the NPP is assumed to apply for both winterover and austral summer personnel assigned to the McMurdo Station from 1962 to 1979. Neutron doses were not calculated for support personnel since those reported for the reactor crew members were less than 5\% of the external gamma doses (Johnson, 1971). Therefore, the reconstructed conservative external gamma doses are assumed to implicitly include a neutron dose estimate along with relevant uncertainty factors.

This exposure scenario does not apply to individuals who made frequent visits to the NPP to perform their specific duties. Doses for frequent visitors to the NPP are discussed in Section 6.4 below. 
Table 11. Parameter values and assumptions for estimating average dose rates inside the NPP facility

\begin{tabular}{|l|c|l|}
\hline \multicolumn{1}{|c|}{ Parameter } & Value & \multicolumn{1}{|c|}{ Rationale/Reference/Comment } \\
\hline Work day & $10 \mathrm{~h} \mathrm{~d}^{-1}$ & Veteran statement \\
\hline Work week & $6 \mathrm{~d} \mathrm{wk}^{-1}$ & Veteran statement \\
\hline Full monitoring period & $59 \mathrm{wk}$ & $\begin{array}{l}\text { Veteran statement } \\
\text { Naval Dosimetry Center } \\
\text { (ASF, 1962-1979) }\end{array}$ \\
\hline Partial monitoring period & $\begin{array}{c}13 \mathrm{wk} \text { (if October to } \\
\text { December) } \\
\text { wk (if January to } \\
\text { November) }\end{array}$ & Naval Dosimetry Center \\
\hline $\begin{array}{l}\text { Austral summer } \\
\text { monitoring period }\end{array}$ & $26 \mathrm{wk}$ & $\begin{array}{l}\text { Veteran statement } \\
\text { Naval Dosimetry Center }\end{array}$ \\
\hline $\begin{array}{l}\text { TLD measurement } \\
\text { results during DF 78 }\end{array}$ & $\begin{array}{c}0.038 \mathrm{rem} \\
\text { (0.38 mSv) }\end{array}$ & NUS Radiological Survey \\
\hline $\begin{array}{l}\text { TLD measurement } \\
\text { duration }\end{array}$ & $76 \mathrm{~d}$ & NUS Radiological Survey \\
\hline $\begin{array}{l}\text { Average film badge } \\
\text { results or surrogate value } \\
\text { for each monitoring year }\end{array}$ & Values shown in & $\begin{array}{l}\text { Table 5 } \\
\text { including film badge results of } \\
\text { crew members who worked in high } \\
\text { dose rate areas that visitors would } \\
\text { have not accessed }\end{array}$ \\
\hline
\end{tabular}

Table 12. Parameter values and assumptions for external dose while visiting the NPP

\begin{tabular}{|l|c|l|}
\hline \multicolumn{1}{|c|}{ Parameter } & Value & \multicolumn{1}{c|}{ Rationale/Reference/Comment } \\
\hline $\begin{array}{l}\text { Time inside the NPP } \\
\text { facility per visit }\end{array}$ & $2 \mathrm{~h}$ & $\begin{array}{l}\text { Reasonable assumption for a tour or } \\
\text { other type of non-work related visit }\end{array}$ \\
\hline $\begin{array}{l}\text { Number of visits per } \\
\text { year or per duty tour }\end{array}$ & 1 & Assumes each person visited once \\
\hline Dose rate while inside & See Table 13 & $\begin{array}{l}\text { Values calculated using parameter } \\
\text { values shown in Table 11 }\end{array}$ \\
\hline
\end{tabular}


Table 13. Estimated average dose rate inside the NPP

\begin{tabular}{|l|l|l|}
\hline DF & $\begin{array}{c}\text { Average Dose Rate } \\
\left(\mathbf{r e m ~} \mathbf{~ h}^{-1}\left(\mathbf{m S v} \mathbf{~ h}^{\mathbf{1}}\right) \mathbf{)}\right.\end{array}$ & \multicolumn{1}{|c|}{$\begin{array}{c}\text { Basis for Estimate of Average } \\
\text { Dose Rate }\end{array}$} \\
\hline 62 & $0.0002(0.002)$ & Full year dosimetry data \\
\hline 63 & $0.0002(0.002)$ & Full year dosimetry data \\
\hline 64 & $0.0002(0.002)$ & Full year dosimetry data \\
\hline 65 & $0.0006(0.006)$ & Full year dosimetry data \\
\hline 66 & $0.0007(0.007)$ & Partial year dosimetry data \\
\hline 67 & $0.0014(0.014)$ & Partial year dosimetry data \\
\hline 68 & $0.0005(0.005)$ & Partial year dosimetry data \\
\hline 69 & $0.0013(0.013)$ & Partial year dosimetry data \\
\hline 70 & $0.0031(0.031)$ & Partial year dosimetry data \\
\hline 71 & $0.0025(0.025)$ & Partial year dosimetry data \\
\hline 72 & $0.002(0.02)$ & Full year dosimetry data \\
\hline 73 & $0.0005(0.005)$ & Full year dosimetry data \\
\hline 74 & $0.0017(0.017)$ & Austral Summer dosimetry data \\
\hline 75 & $0.0011(0.011)$ & $\begin{array}{l}\text { Mean of average dose rates from } \\
\text { all years with film badge data }\end{array}$ \\
\hline 76 & $0.0011(0.011)$ & $\begin{array}{l}\text { Mean of average dose rates from } \\
\text { all years with film badge data }\end{array}$ \\
\hline 77 & $0.00002(0.0002)$ & $\begin{array}{l}\text { TLD measurements from austral } \\
\text { summer of DF 78 }\end{array}$ \\
\hline 78 & $0.00002(0.0002)$ & $\begin{array}{l}\text { TLD measurements from austral } \\
\text { summer of DF 78 }\end{array}$ \\
\hline 79 & $0.00002(0.0002)$ & $\begin{array}{l}\text { TLD measurements from austral } \\
\text { summer of DF 78 }\end{array}$ \\
\hline
\end{tabular}

\subsubsection{Transits in the Proximity of the NPP}

The support personnel were potentially exposed to radiation while moving near the NPP fence, e.g., walking or hiking to Observation Hill as reported by McMurdo veterans (Armstrong, 2012). The external dose for this scenario is estimated by extrapolating the average dose rates inside the NPP (Table 14) to the facility fence line. The estimated dose rates at the facility fence line account for support personnel being exposed outside of the NPP to sources of radiation from the reactor, radioactive components, radioactive waste, and radioactive contamination in the effluent discharge areas. The parameter values and assumptions shown in Table 14 are used to estimate the potential external dose to support personnel while in the proximity of the NPP fence. The doses corresponding to this exposure scenario are calculated using the methods presented in Appendix B. 
Table 14. Parameter values and assumptions for external dose for support personnel transiting near the NPP fence line

\begin{tabular}{|l|c|l|}
\hline \multicolumn{1}{|c|}{ Parameter } & Value & \multicolumn{1}{|c|}{ Rationale/Reference/Comment } \\
\hline Dose rate inside NPP & See Table 13 & $\begin{array}{l}\text { Parameter values above applied to Naval } \\
\text { Dosimetry Center records }\end{array}$ \\
\hline $\begin{array}{l}\text { Distance to representative film } \\
\text { badge location }\end{array}$ & $21 \mathrm{~m}$ & $\begin{array}{l}\text { Distance from radioactive sources to } \\
\text { reactor office and break room (Foster and } \\
\text { Jones, 1982) }\end{array}$ \\
\hline Distance to fence line & $32 \mathrm{~m}$ & $\begin{array}{l}\text { Closest distance from radioactive sources } \\
\text { to fence line (Foster and Jones, 1982) }\end{array}$ \\
\hline Number of transits (per year) & 200 & $\begin{array}{l}\text { Veteran statement over course of a 1-year } \\
\text { tour (Armstrong, 2012) }\end{array}$ \\
\hline Time of transits & $0.25 \mathrm{~h}$ & Reasonable assumption \\
\hline
\end{tabular}

This exposure scenario is assigned for both winter-over and austral summer support personnel from 1962 to 1979. This is based on the assumption that the majority of the transits near the NPP fence line would have occurred in the austral summer months and it overestimates the dose for most veterans.

The use of reactor crew film badge results to estimate doses to support personnel is considered conservative. Because of their duty location, the reactor crew members received a significant portion of their dose while working in close proximity to the reactor containment vessel during maintenance operations rather than while in the reactor office and the break room. In addition, the assumed number of transits is based upon veterans' recollections and should be considered high-sided.

During the VBDR's annual meeting in San Antonio, Texas, on March 23-24, 2012, a McMurdo Station veteran expressed concerns that he was exposed to levels of external radiation above the limits for unrestricted areas in November or December of 1972 while visiting the aviation supply officer who was assumed to be in the area of the helicopter pad that is located approximately 150 yards from the NPP at the base of Observation Hill, even though the location is not certain and could have been as far as 500 yards from the reactor in "downtown McMurdo." The veteran stated that a radiation survey meter that he had just picked up was reading " 3 " but he did not remember the units. In discussions with the veteran, he identified the Victoreen 440 ionization chamber as the most likely survey meter that he was using (VBDR, 2012; Fairchild, 2012b).

A review was made of the October to December 1972 film badge results for the reactor crew members to determine the possibility of radiation levels above the limits for unrestricted areas in the area of the helicopter landing pad. Several reactor crew members who were issued film badges had results indicating that they received external radiation doses of less than 0.2 rem $(2 \mathrm{mSv})$ for the last three months of 1972. If the reactor was creating radiation exposure rates of $0.003 \mathrm{R} \mathrm{h}^{-1}$ (0.03 mGy h${ }^{-1}$ corresponding dose rate) at the 150 yard distance of the helicopter landing pad, which is in the range of the meter the veteran was using, was from the NPP, then the exposure rate in the control room, at 15 yards from the reactor and other areas of the Secondary 
Building, would have been approximately $0.3 \mathrm{R} \mathrm{h}^{-1}\left(3 \mathrm{mGy} \mathrm{h}{ }^{-1}\right)$ using the inverse square law (Cember, 1983). Such a dose rate would result in a quarterly film badge dose of over 200 rem (2000 mSv) if sustained for the entire three month period for which film badge results are available. The film badge results do not support a sustained dose rate of $0.003 \mathrm{R} \mathrm{h}^{-1}$ at 150 yards or further from the NPP. Section 4 includes a review of the dosimetry results for reactor crew members. Also, a review of the incident reports was made and no HPSC reportable incidents were recorded in November or December 1972 to indicate that high radiation alarms were activated inside the facility (Foster and Jones, 1982).

\subsubsection{Immersion in a Cloud of Noble Gases}

The external dose for support personnel who were potentially exposed to radioactive noble gases released from the NPP is estimated by assuming that Ar-41 was emitted at the MPC during the entire period of NPP operations. The parameter values and assumptions shown in Table 15 are used to estimate the dose from this pathway using the methods presented in Appendix B. The Ar-41 immersion dose is assumed to include any dose from radioactive xenon or krypton gases because the release limit for those gases was set well below their 10 CFR 20 limits for unrestricted areas and no report was found that mentioned the limit was exceeded during any operational year (Foster and Jones, 1982).

The noble gas immersion dose is calculated for both winter-over and austral summer-only personnel who were assigned to McMurdo Station from 1962 to 1972 since Ar-41 was released only when the reactor was operational. Other than the time at McMurdo Station, the parameter values used to estimate the doses for winter-over and austral summer personnel are the same.

The external dose estimate for immersion in radioactive noble gases is considered very conservative since the reactor did not emit Ar-41 during the entire time that any individual was at McMurdo Station. Historical reports show that the reactor was shut down on multiple occasions every year, which eliminated the production of Ar-41 during those periods. In addition, Ar-41 gas released from the NPP was diluted and dispersed in the air as it moved away from the stack, but the effects of dispersion were not included in the dose estimates. The very conservativeness of the Ar-41 immersion dose is assumed to include any dose from the release of other noble gases. 
Table 15. Parameter values and assumptions for external dose from immersion in radioactive noble gases

\begin{tabular}{|c|c|c|}
\hline Parameter & Value & Rationale/Reference/Comment \\
\hline $\begin{array}{l}\text { Release concentration } \\
\text { of Ar- } 41\end{array}$ & $\begin{array}{c}1 \times 10^{-8} \mu \mathrm{Ci} \mathrm{mL}{ }^{-1} \\
\left(4 \times 10^{-4}\right. \\
\left.\mathrm{Bq} \mathrm{mL}^{-1}\right)\end{array}$ & $\begin{array}{l}\text { Maximum permissible emissions of Ar- } 41 \text { even } \\
\text { though Ar-41 limit was never exceeded. } \\
\text { Operational limits for other noble gases exceeded } \\
\text { once, but release was below federal effluent } \\
\text { concentration limits, for Xe-133 and Xe-135 } \\
\text { (Foster and Jones, 1982) }\end{array}$ \\
\hline $\begin{array}{l}\text { Effluent concentration } \\
\text { limit for Ar-41 }\end{array}$ & $\begin{array}{c}1 \times 10^{-8} \mu \mathrm{Ci} \mathrm{mL}^{-1} \\
\left(4 \times 10^{-4}\right. \\
\left.\mathrm{Bq} \mathrm{mL}^{-1}\right) \\
\end{array}$ & $\begin{array}{l}\text { Nuclear Regulatory Commission Standards for } \\
\text { Protection Against Radiation (USNRC, 2012b) }\end{array}$ \\
\hline $\begin{array}{l}\text { General public effective } \\
\text { dose from a full year } \\
\text { exposure to effluent } \\
\text { concentration limit }\end{array}$ & $\begin{array}{c}0.05 \mathrm{rem} \\
(0.5 \mathrm{mSv})\end{array}$ & $\begin{array}{l}\text { Nuclear Regulatory Commission Standards for } \\
\text { Protection Against Radiation (USNRC, 2012b) }\end{array}$ \\
\hline $\begin{array}{l}\text { Fraction of time that } \\
\text { wind was blowing from } \\
\text { NPP facility toward } \\
\text { “downtown” McMurdo }\end{array}$ & 0.5 & $\begin{array}{l}\text { McMurdo Station wind rose (Lazzara, 2006) and } \\
\text { NCRP Commentary } 8 \text { (NCRP, 1993) }\end{array}$ \\
\hline $\begin{array}{l}\text { Time at McMurdo } \\
\text { Station for winter-over } \\
\text { personnel }\end{array}$ & $1.2 \mathrm{y}$ & $\begin{array}{l}\text { Veteran statement and dosimetry records (ASF, } \\
\text { 1962-1974) }\end{array}$ \\
\hline $\begin{array}{l}\text { Time at McMurdo } \\
\text { Station for austral } \\
\text { summer personnel }\end{array}$ & $0.5 \mathrm{y}$ & $\begin{array}{l}\text { Veteran statement and dosimetry records (ASF, } \\
\text { 1962-1974) }\end{array}$ \\
\hline
\end{tabular}

\subsubsection{Proximity to Radioactive Waste Packages}

The external dose accrued by support personnel while in the proximity of radioactive waste packages is estimated by assuming that such packages were shipped in accordance with IAEA Safety Series Number Six requirements (Foster and Jones, 1982). It is also assumed that the average dose rate at one meter from the outside surface of the radioactive packages shipped from 1970 to 1972 is representative of the average for all Yellow-III packages. It is assumed that the dose rate at one meter for the Yellow-II packages is the maximum permissible dose rate since no records of the shipping of Yellow-II packages were available (USNRC, 2011a). The parameter values and assumptions shown in Table 16 are used to estimate the external dose from being close to the radioactive waste packages. The doses corresponding to this exposure scenario are calculated using the methods presented in Appendix B.

The parameter values and methods used to estimate the doses for winter-over and austral summer support personnel are the same since radioactive packages were only shipped during the austral summer when both sets of personnel overlapped.

The parameter values used in the external dose estimate for being near radioactive waste packages are considered high-sided because support personnel did not normally handle radioactive waste packages (reactor crew members generally handled the shipping of radioactive waste packages). Also, the average radioactive waste package dose rate includes dose rates 
involving the shipment of spent fuel (U.S. Navy, 1972a; NNPU, 1976), which did not occur every year.

Table 16. Parameter values and assumptions for external dose from proximity to radioactive waste packages

\begin{tabular}{|c|c|c|}
\hline Parameter & Value & Rationale/Reference/Comment \\
\hline $\begin{array}{l}\text { No. of Yellow-III } \\
\text { shipments }\end{array}$ & 10 & $\begin{array}{l}\text { Reasonable assumption based on } \\
\text { shipping documents }\end{array}$ \\
\hline $\begin{array}{l}\text { No. of Yellow-II } \\
\text { shipments }\end{array}$ & 10 & $\begin{array}{l}\text { Reasonable assumption based on } \\
\text { shipping documents }\end{array}$ \\
\hline $\begin{array}{l}\text { Dose rate for } \\
\text { Yellow-III }\end{array}$ & $\begin{array}{c}0.008 \mathrm{R} \mathrm{h}^{-1} \text { at } 1 \mathrm{~m} \\
\left(0.08 \mathrm{mGy} \mathrm{h}^{-1} \text { at } 1 \mathrm{~m}\right)\end{array}$ & $\begin{array}{l}\text { Average dose rate at one meter for } \\
\text { Yellow-III radioactive packages } \\
\text { shipped from McMurdo Station from } \\
1970 \text { to } 1972 \text { (NNPUD, 1972) }\end{array}$ \\
\hline $\begin{array}{l}\text { Dose rate for } \\
\text { Yellow-II }\end{array}$ & $\begin{array}{c}0.001 \mathrm{R} \mathrm{h}^{-1} \text { at } 1 \mathrm{~m} \\
\left(0.01 \mathrm{mGy} \mathrm{h}^{-1} \text { at } 1 \mathrm{~m}\right)\end{array}$ & $\begin{array}{l}\text { Maximum of U.S. Department of } \\
\text { Transportation danger goods package } \\
\text { specifications (USNRC, 2011a) }\end{array}$ \\
\hline $\begin{array}{l}\text { Veteran's distance } \\
\text { from package }\end{array}$ & $3 \mathrm{~m}$ & $\begin{array}{l}\text { Reasonable assumption for high-sided } \\
\text { average distance }\end{array}$ \\
\hline $\begin{array}{l}\text { Time near } \\
\text { radioactive waste } \\
\text { packages }\end{array}$ & $1 \mathrm{~h}$ & $\begin{array}{l}\text { Reasonable maximizing assumption, } \\
\text { not necessarily continuous }\end{array}$ \\
\hline
\end{tabular}

\subsubsection{Proximity to Radioisotope Thermal Generators}

The external dose that support personnel potentially accrued from being in the proximity of RTGs during their shipment is estimated by assuming that packaging and shipping was done in accordance with IAEA Safety Series Number Six requirements (NNPU, 1976). It is also assumed that the average dose rate at one meter from RTG packages measured for the 19701972 shipments is representative for all years (NNPUD, 1972). The parameter values and assumptions shown in Table 17 are used to estimate the external dose from being in the proximity to RTGs packages. The doses corresponding to this exposure scenario are calculated using the methods presented in Appendix B.

The parameter values used to estimate the dose for winter-over support and the austral summer support personnel are the same since RTGs were generally shipped during the austral summer when both types of crews overlapped. The parameter values used to estimate the dose for exposure to RTGs are considered high-sided since many support personnel were not likely exposed to radiation from RTGs. 
Table 17. Parameter values and assumptions for exposure to external radiation from shipments of RTGs

\begin{tabular}{|l|c|l|}
\hline \multicolumn{1}{|c|}{ Parameter } & Value & \multicolumn{1}{c|}{ Rationale/Reference/Comment } \\
\hline $\begin{array}{l}\text { Number of RTG } \\
\text { shipments }\end{array}$ & 1 & $\begin{array}{l}\text { Reasonable assumption based on shipping } \\
\text { documents during decommissioning } \\
\text { (NNPUD, 1972) }\end{array}$ \\
\hline $\begin{array}{l}\text { Dose rates for RTG } \\
\text { shipments }\end{array}$ & $\begin{array}{c}0.003 \mathrm{R} \mathrm{h}^{-1} \text { at } 1 \mathrm{~m} \\
\left(0.03 \mathrm{mGy} \mathrm{h}^{-1} \text { at } 1 \mathrm{~m}\right)\end{array}$ & $\begin{array}{l}\text { Average dose rate measured at one meter } \\
\text { for RTG packages shipped from } \\
\text { McMurdo Station from 1970 to 1972 } \\
\text { (NNPUD, 1972) }\end{array}$ \\
\hline $\begin{array}{l}\text { Veteran's distance } \\
\text { from RTG shipment }\end{array}$ & $3 \mathrm{~m}$ & $\begin{array}{l}\text { Reasonable high-sided assumption for } \\
\text { average distance }\end{array}$ \\
\hline Time near shipments & $1 \mathrm{~h}$ & $\begin{array}{l}\text { Reasonable high-sided assumption, not } \\
\text { necessarily continuous }\end{array}$ \\
\hline
\end{tabular}

\subsubsection{Contaminated Soil on the Ground}

The support personnel at McMurdo Station potentially accrued an external dose from exposure to contaminated soil deposited on the ground from spills that occurred during transport to the loading area or during ship loading. This dose is estimated using the maximum measured activity level of any sample of crushed rock and soil that was shipped in bulk. The external dose from residual soil contamination, after spills were cleaned up, is estimated using the maximum allowed concentration for residual Cs-137 contamination. The parameter values and assumptions shown in Table 18 are used to estimate the dose from contaminated soil on the ground. The doses corresponding to this exposure scenario are calculated using the methods presented in Appendix B.

Table 18. Parameter values and assumption for the external dose from contaminated soil deposited on the ground during decommissioning

\begin{tabular}{|c|c|c|}
\hline Parameter & Value & Rationale/Reference/Comment \\
\hline $\begin{array}{l}\text { Contamination level of } \\
\text { spilled soil }\end{array}$ & $\begin{array}{c}500 \mathrm{pCi} \mathrm{g}^{-1} \\
\left.(19 \mathrm{~Bq} \mathrm{~g})^{-1}\right) \text { of Cs-137 }\end{array}$ & $\begin{array}{l}\text { Maximum contamination } \\
\text { measured in all soil samples in } \\
1978 \text { (Jentz, 1978) }\end{array}$ \\
\hline $\begin{array}{l}\text { Time exposed to } \\
\text { contaminated soil spills }\end{array}$ & $\begin{array}{c}7 \mathrm{~d} \\
10 \mathrm{~h} \mathrm{~d}^{-1}\end{array}$ & $\begin{array}{l}\text { Decommissioning } \\
\text { Health Physics Logs } \\
\text { (NNPU, 1976) }\end{array}$ \\
\hline $\begin{array}{l}\text { Residual contamination } \\
\text { level after soil spills } \\
\text { were cleaned }\end{array}$ & $\begin{array}{c}10 \mathrm{pCi} \mathrm{g}^{-1}\left(0.4 \mathrm{~Bq} \mathrm{~g}^{-1}\right) \\
\text { of Cs-137 }\end{array}$ & $\begin{array}{l}\text { Maximum permissible residual } \\
\text { contamination level of remaining } \\
\text { soil (NNPU, 1973b) }\end{array}$ \\
\hline
\end{tabular}




\begin{tabular}{|c|c|c|}
\hline Parameter & Value & Rationale/Reference/Comment \\
\hline $\begin{array}{l}\text { Time exposed to residual } \\
\text { contamination }\end{array}$ & $\begin{array}{l}420 \mathrm{~d} \\
4 \mathrm{~h} \mathrm{~d}^{-1}\end{array}$ & $\begin{array}{l}\text { Reasonable assumption for high- } \\
\text { sided average given that personnel } \\
\text { spent most of their time indoors. }\end{array}$ \\
\hline Depth of contamination & $0.01 \mathrm{~m}$ & $\begin{array}{l}\text { Assumed spread over an infinite } \\
\text { plane }\end{array}$ \\
\hline $\begin{array}{l}\text { Dose coefficient for } \\
\text { exposure to soil } \\
\text { contaminated with Cs- } \\
137 \text { to a depth of } 1 \mathrm{~cm} \text {. }\end{array}$ & $\begin{array}{c}3.2 \times 10^{-13} \\
\text { Sv per } \mathrm{Bq} \mathrm{m} \mathrm{m}^{-3}\end{array}$ & $\begin{array}{l}\text { Environmental Protection Agency } \\
\text { Federal Guidance Report } 12 \\
\text { (Eckerman and Ryman, 1993) }\end{array}$ \\
\hline Thickness of soil & $0.01 \mathrm{~m}$ & Reasonable assumption \\
\hline Density of soil & $1.3 \times 10^{6} \mathrm{~g} \mathrm{~m}^{-3}$ & $\begin{array}{l}\text { NTPR SOP (DTRA, 2010, SM } \\
\text { ID01) }\end{array}$ \\
\hline
\end{tabular}

Other than the length of time spent at McMurdo Station, the parameter values used to estimate the doses for winter-over and austral summer personnel are the same. The parameter values used to estimate the external dose for exposure to contaminated soil on the ground are considered high-sided because the maximum measured activity concentration in soil is used to calculate the dose. In addition, the assumption that a layer 1-centimeter thick over an infinite plane was formed from the spilled soil and that the spilled soil remained on the ground for seven days is highly conservative.

\subsubsection{Ship Loading of Radioactive Waste}

The external dose for support personnel potentially exposed to radiation during the ship loading of radioactive waste is estimated using self-reading pocket dosimeter results that were recorded in February 1976. The parameter values and assumptions shown in Table 19 are used to estimate the external dose during ship loading. The doses corresponding to this exposure scenario are calculated using the methods presented in Appendix B.

Table 19. Parameter values and assumptions for external dose for ship loading of radioactive waste

\begin{tabular}{|l|c|l|}
\hline \multicolumn{1}{|c|}{ Parameter } & \multicolumn{1}{|c|}{ Value } & \multicolumn{1}{c|}{ Rationale/Reference/Comment } \\
\hline Time exposed & $\begin{array}{c}\text { Two days a year for each } \\
\text { year }(1962-1979)\end{array}$ & Operation Logs (NNPU, 1977a) \\
\hline $\begin{array}{l}\text { Loading dose for two } \\
\text { days }\end{array}$ & $\begin{array}{c}0.035 \mathrm{rem} \\
(0.35 \mathrm{mSv})\end{array}$ & $\begin{array}{l}\text { Mean self-reading dosimeter results } \\
\text { from radiation work permit in } \\
\text { Operation Logs (NNPU, 1977a) }\end{array}$ \\
\hline
\end{tabular}

The external dose from ship loading of radioactive waste is calculated for all winter-over and austral summer personnel since the ship loading occurred during the austral summer over 1 
or 2 days and all veterans are assumed to have been present and received the same dose. The parameter values and method used to estimate the external dose from exposure to radioactive waste during ship loading are considered high-sided because the self-reading dosimeter results were from the year when a large quantity of radioactive waste was shipped (Foster and Jones, 1982). Furthermore, each support personnel member is assumed to have carried out this activity over a 2-day period.

\subsection{Internal Doses-Methods and Assumptions}

The support personnel at McMurdo could have inhaled or ingested radioactive materials released from the NPP or suspended during soil excavation, and transport and loading on ships. For the support personnel who were located at the McMurdo Station during the installation, operation and decommissioning of the NPP, the following potential exposure scenarios and pathways are considered in the assessment of radiation doses from internally-deposited radioactive materials:

1) Inhalation of beta-gamma emitting airborne radioactive materials in emissions of fission and activation products released through the NPP stack or in worldwide fallout.

2) Inhalation of suspended contaminated soil and dust during decommissioning of the NPP.

3) Inhalation of suspended contaminated soil and dust that was spilled on the ground, roads and ship loading areas during transport and loading. Also, inhalation of suspended residual contamination after spill cleanup.

4) Ingestion of drinking water contaminated with tritium either from effluent release or from the use of steam from the NPP.

5) Ingestion of other long-lived beta emitters in drinking water, other than tritium, that could have been in the water from effluent releases from the NPP.

6) Incidental ingestion of contaminated soil and dust that was spilled during the ship-loading process or was residual after spill cleanup.

\subsubsection{Inhalation of Airborne Radioactive Materials}

The internal dose for support personnel from the inhalation of airborne radioactive materials released from the NPP stack and worldwide fallout is estimated using the gross beta air activity concentration monitoring data provided in Table 7 . The parameter values and exposure scenario assumptions shown in Table 20 are used to estimate the internal dose from the inhalation of airborne radioactive materials calculated using the methods presented in Appendix B.

The discussion of airborne activity concentration data included in Foster and Jones (1982) reveals that radioactive materials in air at McMurdo is consistent and strongly correlated with worldwide fallout from past and on-going nuclear tests that were carried out by the U.S., the Soviet Union, France and China during the years 1961 to 1970. To account for the presence of emissions from the McMurdo NPP, it is assumed that the measured activity in air samples is due both to fission products from worldwide fallout and releases from the NPP. 
Examination of the air concentration chart in Table 7 shows that the activity in air sample measurements follow a baseline trend with increases that peak following fallout events as explained in Foster and Jones (1982).

In this dose assessment, the baseline long-lived beta activity from airborne radioactive materials is associated with releases from the NPP and the remainder of the measured air sample activity is assumed to be from worldwide fallout. To estimate the baseline activity threshold that is due to NPP operation, the mean value of the average monthly activity for periods of low worldwide fallout is used. Three periods of low worldwide fallout are identified and are shown in in Table 7 and Figure 7. In the months where the threshold is exceeded, the threshold value is assigned to NPP operation and the remainder is assigned to worldwide fallout. For months where airborne activity is lower than or equal to the threshold, the total value of activity is assigned to the NPP. The baseline activity in air samples is assumed to all be from I-131 aerosols, which would result in higher doses. This is a reasonable assumption based on nuclear power plant operation data, e.g., Calvert Cliffs Nuclear Power Plant, LLC (2009).

Furthermore, because only the activity from particulate radioactive materials is measured in air samples, unmeasured activity in gaseous iodines and hypoiodous acid is accounted for by adding corresponding activity that is estimated using a non-particulate to particle ratio of 9 . This means that 9 times the activity from the air sample measurement, which is presumed to be due to NPP air emissions, is added to account for releases of non-particulate iodines. The ratio of 9 is approximated from data published by Chandrasekaran et al., (1985) and reflects that most particulates are absorbed by ventilation and air effluent filters (Martin, 1964). It is further indicated that, of the iodines released in effluents from pressurized water reactors, about 10 percent of the activity is from particulates and 90 percent is from non-particulates.

As for the component of activity from airborne radioactive materials associated with worldwide fallout, given that no radionuclide analysis is available, the dose is calculated by assuming that all activity from worldwide fallout is from Cs-137. This assumption maximizes the doses from this source and pathway.

The inhalation dose for airborne radioactive materials is calculated for all support personnel at McMurdo Station for all DF years. The inhalation dose for airborne radioactive materials is different for winter-over and austral summer personnel due to differences in length of presence at McMurdo Station.

The parameter values and methodology used to estimate the inhalation dose are considered high-sided in part because background radioactivity was not subtracted from the filter activity concentration results (Foster and Jones, 1982). Furthermore, the activity attributed to reactor operations was assumed to be from I-131because the thyroid dose coefficient for I-131 is higher than the dose coefficients for other long-lived beta emitters that could have been released in the stack emissions from the NPP. Also, the assumption that all activity in worldwide fallout is from Cs-137 high-sides the internal dose to organs, Cs-137 being representative of long-lived fission product in worldwide fallout. Finally, the infiltration factors, which are the ratio of inside concentration to outside concentration, used for this dose calculation are selected to be highsided. 
Table 20. Parameter values and assumption for the internal dose from inhalation of airborne radioactive materials from stack emissions or worldwide fallout

\begin{tabular}{|c|c|c|}
\hline Parameter & Value & Rationale/Reference/Comment \\
\hline $\begin{array}{l}\text { Baseline threshold } \\
\text { of air activity due to } \\
\text { plant operations }\end{array}$ & $\begin{array}{l}0.04 \mathrm{pCi} \mathrm{m}^{-3} \\
\left(1.5 \mathrm{~Bq} \mathrm{~m}^{-3}\right)\end{array}$ & $\begin{array}{l}\text { Average air activity for all months } \\
\text { during periods of low worldwide fallout }\end{array}$ \\
\hline $\begin{array}{l}\text { Air activity } \\
\text { concentration for } \\
\text { worldwide fallout } \\
\text { during plant } \\
\text { operations }\end{array}$ & $\begin{array}{l}\text { Monthly average values } \\
\text { from Table } 7 \text { less the } \\
\text { baseline threshold } \\
\left(\mathrm{pCi} \mathrm{m}^{-3}\left(\mathrm{~Bq} \mathrm{~m}^{-3}\right)\right)\end{array}$ & $\begin{array}{l}\text { Values available from Jan } 1962 \text { to Dec } \\
1972 \text { (Foster and Jones, 1982) }\end{array}$ \\
\hline $\begin{array}{l}\text { Air activity } \\
\text { concentration for } \\
\text { worldwide fallout } \\
\text { after plant } \\
\text { operations ceased }\end{array}$ & $\begin{array}{l}0.04 \mathrm{pCi} \mathrm{m}^{-3} \\
\left(1.5 \mathrm{~Bq} \mathrm{~m}^{-3}\right)\end{array}$ & $\begin{array}{l}\text { Average of monthly air monitoring data } \\
\text { for } 1972 \text { less baseline threshold }\end{array}$ \\
\hline $\begin{array}{l}\text { Air activity } \\
\text { concentration due } \\
\text { to air emissions } \\
\text { from NPP during } \\
\text { plant operation } \\
\end{array}$ & $\begin{array}{l}\text { The smaller of the monthly } \\
\text { average from Table } 7 \text { or } \\
\text { the baseline threshold } \\
\left(\mathrm{pCi} \mathrm{m}^{-3}\left(\mathrm{~Bq} \mathrm{~m}^{-3}\right)\right)\end{array}$ & $\begin{array}{l}\text { Values available from Jan } 1962 \text { to } \\
\text { Dec } 1972 \text { (Foster and Jones, 1982) }\end{array}$ \\
\hline $\begin{array}{l}\text { Fraction of time } \\
\text { outside }\end{array}$ & 0.0167 & $\begin{array}{l}\text { Reasonable high-sided assumption of } \\
\text { four hours per day as an average for an } \\
\text { entire year given that personnel spent } \\
\text { most of their time indoors }\end{array}$ \\
\hline Breathing rate & $0.9 \mathrm{~m}^{3} \mathrm{~h}^{-1}$ & $\begin{array}{l}\text { Value for adult averaged over } 24 \text { hours } \\
\text { (ICRP, 1994a) }\end{array}$ \\
\hline $\begin{array}{l}\text { Ratio of gaseous } \\
\text { iodine to aerosol } \\
\text { iodine }\end{array}$ & 9 & $\begin{array}{l}\text { NUREG-0017 (Chandrasekaran et al., } \\
\text { 1985) }\end{array}$ \\
\hline $\begin{array}{l}\text { Infiltration factor } \\
\text { for aerosols }\end{array}$ & 0.5 & Zhu et al., 2005; Cassata et al., 2012 \\
\hline $\begin{array}{l}\text { Infiltration factor } \\
\text { for gas }\end{array}$ & 1 & Zhu et al., 2005; Cassata et al., 2012 \\
\hline $\begin{array}{l}\text { Time exposure to } \\
\text { airborne radioactive } \\
\text { material (winter- } \\
\text { over) }\end{array}$ & $24 \mathrm{~h} \mathrm{~d}^{-1}$ for $420 \mathrm{~d}$ & Reasonable assumption \\
\hline $\begin{array}{l}\text { Time exposure to } \\
\text { airborne radioactive } \\
\text { material (austral } \\
\text { summer) }\end{array}$ & $24 \mathrm{~h} \mathrm{~d}^{-1}$ for $180 \mathrm{~d}$ & Reasonable assumption \\
\hline
\end{tabular}




\begin{tabular}{|c|l|c|}
\hline Parameter & \multicolumn{1}{|c|}{ Value } & \multicolumn{1}{c|}{ Rationale/Reference/Comment } \\
\hline Dose coefficients & $\begin{array}{l}\text { Depends on organ } \\
\text { 5-micrometer }(\mu \mathrm{m}) \text { particle } \\
\text { size, I-131 and Cs-137 for } \\
\text { aerosol and elemental } \\
\text { iodine for gaseous form } \\
\left(\text { rem } \mathrm{Ci}^{-1}\left(\mathrm{~Sv} \mathrm{~Bq}^{-1}\right)\right)\end{array}$ & $\begin{array}{l}\text { ICRP Publication 68 (ICRP, 1994b) } \\
\text { Results in highest doses for most organs }\end{array}$ \\
\hline
\end{tabular}

\subsubsection{Inhalation of Suspended Contaminated Soil during Decommissioning}

The internal dose for support personnel from their inhalation of suspended contaminated soil during decommissioning is estimated using air sampling activity concentration data taken during the decommissioning process (NNPU, 1976; NNPU, 1977b). The parameter values and assumptions shown in Table 21 are used to estimate the internal dose from the inhalation of suspended contaminated soil during decommissioning. This internal dose is calculated using the methods presented in Appendix B.

Table 21. Parameter values and assumption for the internal dose from inhalation of suspended contaminated soil during decommissioning

\begin{tabular}{|c|c|c|}
\hline Parameter & Value & Rationale/Reference/Comment \\
\hline $\begin{array}{l}\text { Air activity } \\
\text { concentration }\end{array}$ & $\begin{array}{c}\mathrm{Ci} \mathrm{m}^{-3}\left(\mathrm{~Bq} \mathrm{~m}^{-3}\right) \\
\text { (Cs-137) derived from } \\
\text { Table } 8\end{array}$ & $\begin{array}{l}\text { Used highest value from air sampling } \\
\text { results reported in the } \\
\text { Decommissioning Health Physics } \\
\text { Logs (NNPU, 1976; NNPU, 1977b) }\end{array}$ \\
\hline Time outside & $\begin{array}{c}10 \mathrm{~h} \mathrm{~d}^{-1} \\
6 \mathrm{~d} \mathrm{wk}^{-1} \text { for } \\
6 \text { months (summer tour) }\end{array}$ & $\begin{array}{l}\text { Veteran's statements about workday } \\
\text { and activities carried out only during } \\
\text { austral summers }\end{array}$ \\
\hline Breathing rate & $1.2 \mathrm{~m}^{3} \mathrm{~h}^{-1}$ & ICRP Publication 66 (ICRP, 1994a) \\
\hline Dose coefficients & $\begin{array}{c}\text { Depends on organ } \\
(5-\mu \mathrm{m} \text { particle size, } \\
\text { all Cs-137) (rem } \mathrm{Ci}^{-1} \\
\left.\left.\quad(\mathrm{~Sv} \mathrm{~Bq})^{-1}\right)\right)\end{array}$ & $\begin{array}{l}\text { ICRP Publication } 68 \text { (ICRP, 1994b) } \\
\text { Results in highest doses for most } \\
\text { organs }\end{array}$ \\
\hline
\end{tabular}

The inhalation dose from suspended contaminated soil is calculated for all support personnel who were at McMurdo Station during decommissioning of the NPP for DF 75 to 79. The methodology should also be used for reactor crew members who were at McMurdo Station during DF 75 to 79.

The parameter values and methodology used to estimate the internal doses from the inhalation of suspended contaminated soil during decommissioning are considered high-sided because the highest air sampling result is used. Also the time spent outside during decommissioning was assumed to be the maximum possible length. 


\subsubsection{Inhalation of Suspended Contaminated Soil Spilled on the Ground, Roads and Ship Loading Areas}

The internal dose that support personnel potentially accrued from the inhalation of suspended contaminated soil spilled during bulk soil transport and ship loading operations is estimated using the maximum measured soil concentration levels of Cs-137. The internal dose from inhalation of suspended residual contaminated soil is estimated using the maximum soil concentration levels of Cs-137 that may have remained after cleanup. The parameter values and exposure scenario assumptions shown in Table 22 are used to estimate the internal dose from the inhalation of suspended soil using the methods presented in Appendix B.

Table 22. Parameter values and assumptions for the internal dose from inhalation of suspended contaminated soil that was spilled on the ground, roads and ship loading areas

\begin{tabular}{|c|c|c|}
\hline Parameter & Value & Rationale/Reference/Comment \\
\hline $\begin{array}{l}\text { Activity concentration of } \\
\text { contaminated soil }\end{array}$ & $\begin{array}{c}500 \mathrm{pCi} \mathrm{g}^{-1} \\
\left(20 \mathrm{~Bq} \mathrm{~g}^{-1}\right) \text { of Cs-137 }\end{array}$ & $\begin{array}{l}\text { Maximum contamination measured } \\
\text { in all soil samples in } 1978 \\
\text { (Jentz, 1978) }\end{array}$ \\
\hline $\begin{array}{l}\text { Time exposed to suspended } \\
\text { contaminated soil }\end{array}$ & $\begin{array}{c}7 \mathrm{~d} \\
10 \mathrm{~h} \mathrm{~d}^{-1}\end{array}$ & $\begin{array}{l}\text { Health Physics Logs (NNPU, } \\
\text { 1977b) and veteran’s statements } \\
\text { about workday }\end{array}$ \\
\hline $\begin{array}{l}\text { Residual contamination } \\
\text { level after cleanup }\end{array}$ & $\begin{array}{c}10 \mathrm{pCi} \mathrm{g}^{-1}\left(0.4 \mathrm{~Bq} \mathrm{~g}^{-1}\right) \text { of } \\
\mathrm{Cs}-137\end{array}$ & $\begin{array}{l}\text { Decommissioning Plan and Health } \\
\text { Physics Logs (NNPU, 1976; } \\
\text { NNPU, 1977b) }\end{array}$ \\
\hline $\begin{array}{l}\text { Time exposed to residual } \\
\text { contamination (winter-over) }\end{array}$ & $4 \mathrm{~h} \mathrm{~d}^{-1}$ for 420 days & $\begin{array}{l}\text { Reasonable assumption for residual } \\
\text { contamination }\end{array}$ \\
\hline $\begin{array}{l}\text { Time exposed to residual } \\
\text { contamination (austral } \\
\text { summer) }\end{array}$ & $4 \mathrm{~h} \mathrm{~d}^{-1}$ for 180 days & $\begin{array}{l}\text { Reasonable assumption for residual } \\
\text { contamination }\end{array}$ \\
\hline Suspension factor & $1 \times 10^{-5} \mathrm{~m}^{-1}$ & $\begin{array}{l}\text { NTPR SOP (DTRA, 2010, } \\
\text { SM ID01) }\end{array}$ \\
\hline Depth of contamination & $1 \mathrm{~cm}$ & $\begin{array}{l}\text { NTPR SOP (DTRA, 2010, } \\
\text { SM ID01) }\end{array}$ \\
\hline Dose coefficients & $\begin{array}{c}\text { Depends on organ } \\
(5-\mu m \text { particle size, } \\
\text { all Cs-137) } \\
\left(\operatorname{rem~Ci}{ }^{-1}\left(\mathrm{~Sv} \mathrm{~Bq}^{-1}\right)\right)\end{array}$ & $\begin{array}{l}\text { ICRP Publication } 68 \text { (ICRP, 1994b) } \\
\text { Results in highest doses for most } \\
\text { organs }\end{array}$ \\
\hline
\end{tabular}

The inhalation dose from spilled contaminated soil is calculated for all support personnel who were at McMurdo Station during the decommissioning of the NPP from DF 75 to 79. The lengths of time at McMurdo Station are different for winter-over and austral summer personnel. 
This pathway is also applicable to reactor decommissioning crew members who were at McMurdo Station during DF 75 to 79.

The parameter values and methods used to estimate the internal doses from inhalation of suspended contaminated soil are considered high-sided because most of the spilled soil would have contained less than $500 \mathrm{pCi} \mathrm{g}^{-1}\left(10 \mathrm{~Bq} \mathrm{~g}^{-1}\right)$. Also, any minor spills during transportation of the bulk soil would not have left contaminated soil to a depth of one centimeter everywhere a person walked for the length of time assumed.

\subsubsection{Ingestion of Tritium in Drinking Water}

The internal dose that support personnel potentially accrued from the ingestion of tritium in the drinking water is estimated using concentration measurements of the tritium in drinking water concentration measurements from 1967 to 1972 or the average monthly concentration for all months before 1967 or after 1972 (Table 10). The parameter values and assumptions shown in Table 23 are used to estimate the internal dose from the ingestion of tritium in drinking water. This dose is calculated using with the methods presented in Appendix B.

Table 23. Parameter values and assumptions for the internal dose from ingestion of tritium in drinking water

\begin{tabular}{|c|c|c|}
\hline Parameter & Value & Rationale/Reference/Comment \\
\hline $\begin{array}{l}\text { Tritium } \\
\text { concentration } \\
\text { in drinking water }\end{array}$ & $\begin{array}{l}\text { Monthly average of } \\
\text { weekly samples } \\
\text { pCi L }^{-1}\left(\mathrm{~Bq} \mathrm{~L}^{-1}\right)\end{array}$ & $\begin{array}{l}\text { Data available from Mar } 1967 \text { to } \\
\text { Nov } 1972 \text { (Foster and Jones, 1982) }\end{array}$ \\
\hline $\begin{array}{l}\text { Tritium } \\
\text { concentration in } \\
\text { drinking water } \\
\text { during unmonitored } \\
\text { months }\end{array}$ & $\begin{array}{l}1 \times 10^{5} \mathrm{pCi} \mathrm{L}^{-1} \\
\left(3,900 \mathrm{~Bq} \mathrm{~L}^{-1}\right)\end{array}$ & $\begin{array}{l}\text { Average of all tritium monitoring } \\
\text { results from May } 1967 \text { to } \\
\text { November } 1972 \text { (Foster and Jones, } \\
\text { 1982). }\end{array}$ \\
\hline Water intake & $\begin{array}{c}6 \mathrm{~L} \mathrm{~d}^{-1} \\
420 \mathrm{~d} \text { (winter-over) } \\
180 \mathrm{~d} \text { (austral summer) }\end{array}$ & $\begin{array}{l}\text { Mean value for an adult is } 1.5 \mathrm{~L} \mathrm{~d}^{-1} \\
\text { (USEPA, 2011). Increased water } \\
\text { intake in the extreme cold and dry } \\
\text { environmental conditions in } \\
\text { Antarctica (Montain and Matthew, } \\
2010 \text { ) }\end{array}$ \\
\hline Dose coefficients & $\begin{array}{l}\text { Depends on organ } \\
\left(\mathrm{Sv} \mathrm{Bq}{ }^{-1}\right)\end{array}$ & $\begin{array}{l}\text { ICRP Publication } 68 \text { (ICRP, } \\
\text { 1994b) }\end{array}$ \\
\hline
\end{tabular}

The winter-over and austral summer personnel would accrue different doses from the ingestion of tritium in drinking water due to the length of presence at McMurdo Station. This dose pathway is also applicable to reactor crew members because drinking water consumption is a pathway for all personnel.

The parameter values and methods used to estimate the internal doses for the ingestion of tritium in drinking water are considered high-sided in part because background radiation is included in the tritium activity concentration; the natural background levels for tritium are 
approximately 50 to $100 \mathrm{pCi} \mathrm{L}^{-1}$ (2 to $4 \mathrm{~Bq} \mathrm{~L}^{-1}$ ) (ASTSWMO, 2009). In addition, the water intake value is conservative to take into account the possibility of increased water consumption caused by the cold and dry environmental conditions in Antarctica.

\subsubsection{Ingestion of Long-Lived Beta Emitters in Drinking Water other than Tritium}

The internal dose that support personnel potentially accrued from the ingestion of longlived beta emitters in drinking water, other than tritium, is estimated using the results of the drinking water monitoring activity concentration data from 1962 to 1972 along with surrogate data for 1973 to 1979 (Table 9). The parameter values and assumptions given in Table 24 are used to estimate the internal dose from the ingestion of drinking water using the methods presented in Appendix B.

Table 24. Parameter values and assumptions for the internal dose from ingestion of long-lived beta emitters in drinking water other than tritium

\begin{tabular}{|l|c|l|}
\hline \multicolumn{1}{|c|}{ Parameter } & \multicolumn{1}{c|}{ Value } & \multicolumn{1}{c|}{ Rationale/Reference/Comment } \\
\hline $\begin{array}{l}\text { Beta activity } \\
\text { concentration in } \\
\text { drinking water }\end{array}$ & $\begin{array}{c}\text { Monthly average } \\
\left(\mathrm{Bq} \mathrm{L}^{-1}\right)\end{array}$ & $\begin{array}{l}\text { Values from January 1962 to December 1972 } \\
\text { (Foster and Jones, 1982) } \\
\text { Assumed December 1972 drinking water } \\
\text { concentration for months between January 1973 } \\
\text { to March 1979 }\end{array}$ \\
\hline Water intake & $6 \mathrm{~L} \mathrm{~d}^{-1}$ & $\begin{array}{l}\text { Mean value for an adult is 1.5 L d } \mathrm{d}^{-1} \text { (USEPA, } \\
\text { 2011). Increased water intake in the extreme } \\
\text { cold and dry environmental conditions in } \\
\text { Antarctica (Montain and Matthew, 2010) }\end{array}$ \\
\hline Dose coefficients & $\begin{array}{r}\text { Depends on organ } \\
(\text { all Cs-137) } \\
\left(\text { rem Ci } \mathrm{Ci}^{-1}\left(\mathrm{~Sv} \mathrm{~Bq}^{-1}\right)\right)\end{array}$ & $\begin{array}{l}\text { ICRP Publication 68 (ICRP, 1994b) } \\
\text { Results in highest doses for most organs }\end{array}$ \\
\hline
\end{tabular}

The winter-over and austral summer personnel would have accrued different doses from the ingestion of drinking water due to the length of presence at McMurdo Station. This exposure pathway is also applicable to reactor crew members because the drinking water consumption is a pathway for all personnel.

The parameter values and methods used to estimate the internal doses for ingestion of beta emitters in drinking water are considered high-sided in part because background radiation is included in the water activity concentration data. Also, the dose estimate assumes all radioactivity is from Cs-137 instead of assuming that some of the activity is due to beta emitters with lower dose coefficients. In addition, the water intake value is conservative to take into account the possibility of increased water consumption in the cold and dry environmental conditions in Antarctica. 


\subsubsection{Incidental Ingestion of Contaminated Soil and Dust}

The internal doses that support personnel potentially accrued from the incidental ingestion of contaminated soil and dust during decommissioning is estimated using the results of soil monitoring. The parameter values and assumptions provided in Table 25 are used to estimate the internal dose from the incidental ingestion of soil and dust. This dose is calculated using the methods presented in Appendix B.

Table 25. Parameter values and assumptions for the internal dose from incidental ingestion of contaminated soil and dust

\begin{tabular}{|l|c|l|}
\hline \multicolumn{1}{|c|}{ Parameter } & \multicolumn{1}{|c|}{ Value } & \multicolumn{1}{|c|}{ Rationale/Reference/Comment } \\
\hline $\begin{array}{l}\text { Concentration of } \\
\text { contaminants in soil }\end{array}$ & $\begin{array}{c}500 \mathrm{pCi} \mathrm{g}^{-1} \\
\left(20 \mathrm{~Bq} \mathrm{~g}^{-1}\right) \\
\text { of Cs-137 }\end{array}$ & $\begin{array}{l}\text { Maximum contamination measured in all } \\
\text { soil samples in 1978 (Jentz, 1978) }\end{array}$ \\
\hline Ingestion rate & $0.05 \mathrm{~g} \mathrm{~d}^{-1}$ & $\begin{array}{l}\text { Value from USEPA (2011) and military } \\
\text { guidance. Also based on NTPR standard } \\
\text { operating procedure ID01 (DTRA, 2010, } \\
\text { SM ID01) }\end{array}$ \\
\hline $\begin{array}{l}\text { Days ingesting } \\
\text { contaminated soil }\end{array}$ & $\begin{array}{l}\text { Decommissioning Health Physics Logs } \\
\text { (NNPU, 1977b) }\end{array}$ \\
\hline $\begin{array}{l}\text { Residual soil } \\
\text { contamination level } \\
\text { after spills were cleaned }\end{array}$ & $\begin{array}{l}10 \mathrm{pCi} \mathrm{g}^{-1} \\
\text { of Cs-137 }\end{array}$ & $\begin{array}{l}\text { Maximum permissible residual } \\
\text { concentration in soil (Decommissioning } \\
\text { Plan (NNPU, 1973b) and Health Physics } \\
\text { Logs (NNPU, 1977b) ) }\end{array}$ \\
\hline $\begin{array}{l}\text { Days ingesting soil with } \\
\text { residual contamination } \\
\text { (winter-over personnel) }\end{array}$ & $420 \mathrm{~d}$ & $\begin{array}{l}\text { Reasonable assumption based on 14 } \\
\text { month tour }\end{array}$ \\
\hline $\begin{array}{l}\text { Days ingesting soil with } \\
\text { residual contamination } \\
\text { (austral summer } \\
\text { personnel) }\end{array}$ & $180 \mathrm{~d}$ & $\begin{array}{l}\text { Reasonable assumption based on 6 month } \\
\text { tour }\end{array}$ \\
\hline Dose coefficients & $\begin{array}{l}\text { Depends on organ } \\
\text { (all Cs-137) }\end{array}$ & $\begin{array}{l}\text { ICRP Publication 68 (ICRP, 1994b) } \\
\text { Results in highest doses for most organs }\end{array}$ \\
\hline
\end{tabular}

The dose from the incidental ingestion of contaminated soil and dust is calculated for all support personnel who were at McMurdo Station during the decommissioning of the NPP for DF 75 to 79. The parameter values used for the doses for the winter-over and austral summer personnel are different since the winter-over personnel would have been exposed to residual soil contamination for a longer time. The dose pathway is also applicable to reactor crew members who were at the McMurdo Station during DF 75 to 79.

The parameter values and methods used to estimate the internal doses from the incidental ingestion of contaminated soil and dust are considered high-sided because spilled contaminated soil would not generally have remained on the ground for seven days after the spill and before 
cleanup. In addition, not all of the spilled contaminated soil would have contained the maximum measured level of contamination.

\subsection{Uncertainties and Upper-Bound Doses}

Several sources of uncertainty in estimating external and internal doses to veterans in this assessment are attributed to imperfection in measuring instruments, procedural errors, and data recording and processing uncertainties, among others. The following is a non-comprehensive list of potential sources of uncertainties:

- $\quad$ Instrument precision, operator measurement and recording errors.

- $\quad$ Uncertainties due to data processing tools.

- $\quad$ Spatial variability when only average values are reported or a few measurements are taken.

- $\quad$ Variability in the exposure times.

- $\quad$ Uncertainties in breathing rates and water consumption rates.

- $\quad$ Uncertainty in dose coefficients for iodine and cesium.

- $\quad$ Uncertainties in the isotopic mix of radioactive materials.

\subsubsection{External Doses}

Following the procedures used for NTPR dose calculations, an uncertainty factor of 3 is assigned to each external dose component calculated for the McMurdo Station support personnel (Kocher, 2009; DTRA, 2010, Standard Method ED02). Also, the components of the external dose are assumed to be uncorrelated i.e., they vary independent of each other. Therefore, to determine an upper-bound external dose, the uncertainties of the external dose components are combined in quadrature (DTRA, 2010, Standard Method UA01) as described in Appendix B. Using this uncertainty approach, the upper-bound dose is considered to exceed the $95^{\text {th }}$ percentile dose determined from a hypothetical distribution of film badge doses for individuals exposed to the same sources of radiation. In addition, the uncertainty factor accounts for relatively small doses that are less than a few percent of the overall external dose, e.g., dose from proximity to radioactive sample packages shipped as White-I.

\subsubsection{Internal Doses}

Following the procedures used for NTPR dose calculations, an uncertainty factor of 10 is assigned to each internal dose calculated for the McMurdo Station support personnel. The uncertainties of the internal dose are assumed to be correlated. The upper-bounds of each component of the internal dose are summed to estimate the upper-bound internal dose for either the committed effective dose or the organ dose as described in Appendix B. The upper-bound internal dose is considered to exceed the $95^{\text {th }}$ percentile dose determined from a hypothetical distribution of doses for individuals estimated from internal monitoring measurements 
(NAS/NRC, 2003; DTRA, 2010, Standard Method ID01). In addition, the uncertainty factor for internal doses accounts for relatively small doses that are less than a few percent of the overall internal dose, e.g., occasional consumption of locally-caught seafood. 


\section{6. \\ Support Personnel Dose Assessment Results and Discussion}

\subsection{External Dose}

The external doses and upper-bounds for winter-over and austral summer support personnel who were assigned to McMurdo Station during DF 62 to 79 are presented in Table 26 and Table 27, respectively. The results include the dose estimates for each component of the external dose for each year or austral summer, the total external dose from all components, and the corresponding upper-bound doses. The external dose and upper-bounds are the same for all organs.

\subsection{Internal Dose}

The internal doses and upper-bounds for winter-over and austral summer support personnel who were assigned to McMurdo Station during DF 62 to 79 are provided in Table 28 and Table 29, respectively. The results include the 50-year committed effective dose and the 50-year committed equivalent dose to the thyroid and the red bone marrow for each pathway and each year or austral summer, the total internal dose from all pathways, and the corresponding upper-bound internal dose. The thyroid was chosen as an organ of interest because of the assumption that much of the airborne radioactive materials were made of iodines. The red bone marrow was chosen due to leukemia being the most common radiation induced cancer. The 50year committed effective dose is the sum of the products of the committed equivalent dose delivered over a 50-year period after exposure and the appropriate weighting factor for all organs and tissues (ICRP, 1991).

\subsection{Discussion}

A summary of the upper-bound external and internal dose results and the corresponding total doses for McMurdo Station support personnel during DF 62 to 79 is given in Table 30.

The highest external upper-bound dose of 0.4 rem ( $4 \mathrm{mSv})$ is calculated for DF 70, which was the year when there was a core change during the middle of winter that lead to higher average film badge doses and resulted in the highest dose component for transiting near the NPP. The lowest external upper-bound dose is $0.2 \mathrm{rem}(2 \mathrm{mSv})$ and was estimated for the decommissioning period when the largest sources of external exposure were from the movement of radioactive waste.

The highest upper-bound internal dose for the organs considered is 0.4 rem (4 mSv) and is for DF 67, which is the year with the highest tritium doses. The lowest upper-bound internal 
dose for the organs considered is 0.02 rem $(0.2 \mathrm{mSv})$ and is calculated for DF 77, 78, and 79, which is the period during decommissioning after the reactor core had been returned to the U.S. .

The highest total dose for the organs considered is 0.6 rem (6 mSv)and corresponds to DF 67. The lowest total upper-bound dose for any organ considered is 0.2 rem (2 mSv) and is for DF 77, 78 and 79 during decommissioning after the reactor core had been returned to the U.S.

\subsection{Other Exposure Scenarios}

All estimated doses and upper-bounds reported here are generic cohort doses that can be assigned to any McMurdo Station support personnel veteran who had activities and exposures covered in this assessment for the period between 1962 and 1979. However, some support personnel may have been exposed to additional or distinctly different sources of radiation that were associated with activities and functions that did not fall into the scenarios and pathways assessed in this report. For these veterans, proposed guidelines are provided in Section 8 for performing individualized radiation dose assessments that would include exposure scenarios that were not evaluated in this report. 
Table 26. External doses and upper-bounds for winter-over support personnel

\begin{tabular}{|c|c|c|c|c|c|c|c|c|c|c|c|c|c|c|c|c|c|c|}
\hline \multicolumn{19}{|c|}{ External Dose (rem*) } \\
\hline Pathway & DF62 & DF63 & DF64 & DF65 & DF66 & DF67 & DF68 & DF69 & DF70 & DF71 & DF72 & DF73 & DF74 & DF75 & DF76 & DF77 & DF78 & DF79 \\
\hline Plant tour/visit & - & - & - & 0.002 & 0.002 & 0.003 & 0.001 & 0.003 & 0.007 & 0.005 & 0.004 & 0.001 & 0.004 & 0.003 & 0.003 & - & - & - \\
\hline Transit near NPP & 0.005 & 0.005 & 0.005 & 0.02 & 0.02 & 0.04 & 0.02 & 0.03 & 0.07 & 0.06 & 0.05 & 0.02 & 0.04 & 0.03 & 0.03 & - & - & - \\
\hline $\begin{array}{l}\text { Noble gas } \\
\text { Immersion }\end{array}$ & 0.02 & 0.03 & 0.03 & 0.03 & 0.03 & 0.03 & 0.03 & 0.03 & 0.03 & 0.03 & 0.03 & 0.03 & - & - & - & - & - & - \\
\hline $\begin{array}{l}\text { Spilled } \\
\text { contaminated soil }\end{array}$ & - & - & - & - & - & - & - & - & - & - & - & - & - & - & 0.004 & 0.004 & 0.004 & 0.004 \\
\hline $\begin{array}{l}\text { Radioactive waste } \\
\text { package }\end{array}$ & 0.01 & 0.01 & 0.01 & 0.01 & 0.01 & 0.01 & 0.01 & 0.01 & 0.01 & 0.01 & 0.01 & 0.01 & 0.01 & 0.01 & 0.01 & 0.01 & 0.01 & 0.01 \\
\hline RTGs & - & - & - & - & - & - & - & - & - & - & - & - & - & - & - & - & - & - \\
\hline Ship loading & 0.04 & 0.04 & 0.04 & 0.04 & 0.04 & 0.04 & 0.04 & 0.04 & 0.04 & 0.04 & 0.04 & 0.04 & 0.04 & 0.04 & 0.04 & 0.04 & 0.04 & 0.04 \\
\hline Total $^{\dagger}$ & 0.07 & 0.08 & 0.08 & 0.09 & 0.1 & 0.2 & 0.09 & 0.2 & 0.2 & 0.2 & 0.2 & 0.09 & 0.09 & 0.08 & 0.08 & 0.05 & 0.05 & 0.05 \\
\hline Upper-Bound & 0.2 & 0.2 & 0.2 & 0.2 & 0.2 & 0.3 & 0.2 & 0.3 & 0.4 & 0.3 & 0.3 & 0.2 & 0.2 & 0.2 & 0.2 & 0.2 & 0.2 & 0.2 \\
\hline
\end{tabular}

* $1 \mathrm{rem}=10 \mathrm{mSv}$, "-" means $<0.001 \mathrm{rem}$

${ }^{\dagger}$ Total doses may not match the sum of pathway dose components because all results are rounded up to one significant digit.

Table 27. External doses and upper-bounds for austral summer support personnel

\begin{tabular}{|c|c|c|c|c|c|c|c|c|c|c|c|c|c|c|c|c|c|c|}
\hline \multicolumn{19}{|c|}{ External dose (rem*) } \\
\hline Pathway & DF62 & DF63 & DF64 & DF65 & DF66 & DF67 & DF68 & DF69 & DF70 & DF71 & DF72 & DF73 & DF74 & DF75 & DF76 & DF77 & DF78 & DF79 \\
\hline Plant tour/visit & - & - & - & 0.002 & 0.002 & 0.003 & 0.001 & 0.003 & 0.007 & 0.005 & 0.004 & 0.001 & 0.004 & 0.003 & 0.003 & - & - & - \\
\hline Transit near NPP & 0.005 & 0.005 & 0.005 & 0.02 & 0.02 & 0.04 & 0.02 & 0.03 & 0.07 & 0.06 & 0.05 & 0.02 & 0.04 & 0.03 & 0.03 & - & 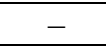 & - \\
\hline $\begin{array}{l}\text { Noble gas } \\
\text { Immersion }\end{array}$ & 0.02 & 0.02 & 0.02 & 0.02 & 0.02 & 0.02 & 0.02 & 0.02 & 0.02 & 0.02 & 0.02 & 0.02 & - & - & - & - & - & - \\
\hline \begin{tabular}{|l|} 
Spilled \\
contaminated soil
\end{tabular} & - & - & - & - & - & - & - & - & - & - & - & - & - & 0.003 & 0.003 & 0.003 & 0.003 & 0.003 \\
\hline $\begin{array}{l}\text { Radioactive } \\
\text { waste package }\end{array}$ & 0.01 & 0.01 & 0.01 & 0.01 & 0.01 & 0.01 & 0.01 & 0.01 & 0.01 & 0.01 & 0.01 & 0.01 & 0.01 & 0.01 & 0.01 & 0.01 & 0.01 & 0.01 \\
\hline RTG movement & - & - & - & - & - & - & - & - & - & - & - & - & - & - & - & - & - & - \\
\hline Ship loading & 0.04 & 0.04 & 0.04 & 0.04 & 0.04 & 0.04 & 0.04 & 0.04 & 0.04 & 0.04 & 0.04 & 0.04 & 0.04 & 0.04 & 0.04 & 0.04 & 0.04 & 0.04 \\
\hline \begin{tabular}{|r|} 
Total $^{\dagger}$ \\
\end{tabular} & 0.07 & 0.07 & 0.07 & 0.08 & 0.08 & 0.1 & 0.07 & 0.09 & 0.2 & 0.2 & 0.2 & 0.07 & 0.09 & 0.08 & 0.08 & 0.05 & 0.05 & 0.05 \\
\hline Upper-Bound & 0.2 & 0.2 & 0.2 & 0.2 & 0.2 & 0.2 & 0.2 & 0.2 & 0.3 & 0.3 & 0.3 & 0.2 & 0.2 & 0.2 & 0.2 & 0.2 & 0.2 & 0.2 \\
\hline
\end{tabular}

${ }^{*} 1 \mathrm{rem}=10 \mathrm{mSv}$, "-" means $<0.001$ rem

Total doses may not match the sum of pathway dose components because all results are rounded up to one significant digit. 
Table 28. Internal doses and upper-bounds for winter-over support personnel

\begin{tabular}{|c|c|c|c|c|c|c|c|c|c|c|c|c|c|c|c|c|c|c|}
\hline Pathway & DF62 & DF63 & DF64 & DF65 & DF66 & DF67 & DF68 & DF69 & DF70 & DF71 & DF72 & DF73 & DF74 & DF75 & DF76 & DF77 & DF78 & DF79 \\
\hline \multicolumn{19}{|c|}{ Effective (Whole-Body) Dose (rem) } \\
\hline $\begin{array}{l}\text { Inhalation of } \\
\text { airborne } \\
\text { radioactivity }\end{array}$ & - & - & - & - & - & - & - & - & - & - & - & - & - & - & - & - & - & - \\
\hline $\begin{array}{l}\begin{array}{l}\text { Inhalation of } \\
\text { suspended soil }\end{array} \\
\end{array}$ & - & - & - & - & - & - & - & - & - & - & - & - & - & - & - & - & - & - \\
\hline $\begin{array}{l}\text { Inhalation of } \\
\text { spilled soil }\end{array}$ & - & - & - & - & - & - & - & - & - & - & - & - & - & - & - & - & - & - \\
\hline Water ingestion & 0.002 & 0.002 & 0.002 & 0.003 & 0.002 & 0.002 & - & 0.004 & 0.002 & - & 0.002 & 0.001 & 0.002 & 0.002 & 0.002 & 0.002 & 0.002 & 0.002 \\
\hline $\begin{array}{l}\text { Ingestion of } \\
\text { water (tritium) }\end{array}$ & 0.003 & 0.005 & 0.005 & 0.005 & 0.005 & 0.03 & 0.009 & 0.007 & 0.005 & 0.002 & 0.002 & 0.004 & 0.005 & 0.005 & 0.005 & 0.005 & 0.005 & 0.005 \\
\hline Soil ingestion & - & - & - & - & - & - & - & - & - & - & - & - & - & - & - & - & - & - \\
\hline $\begin{array}{r}\text { Total }^{\dagger} \\
\end{array}$ & 0.004 & 0.006 & 0.006 & 0.007 & 0.006 & 0.04 & 0.01 & 0.02 & 0.007 & 0.003 & 0.003 & 0.005 & 0.006 & 0.007 & 0.007 & 0.007 & 0.007 & 0.007 \\
\hline Upper-Bound & 0.04 & 0.06 & 0.06 & 0.07 & 0.06 & 0.4 & 0.1 & 0.2 & 0.07 & 0.03 & 0.03 & 0.05 & 0.06 & 0.07 & 0.07 & 0.07 & 0.07 & 0.07 \\
\hline \multicolumn{19}{|c|}{ Thyroid (rem*) } \\
\hline \begin{tabular}{|l|} 
Inhalation of \\
airborne \\
radioactivity
\end{tabular} & 0.004 & 0.005 & 0.005 & 0.005 & 0.004 & 0.005 & 0.005 & 0.005 & 0.005 & 0.005 & 0.005 & - & - & - & - & - & 0.004 & 0.005 \\
\hline \begin{tabular}{|l}
$\begin{array}{l}\text { Inhalation of } \\
\text { suspended soil }\end{array}$ \\
\end{tabular} & - & - & - & - & - & - & - & - & - & - & - & - & - & - & - & - & - & - \\
\hline \begin{tabular}{|l}
$\begin{array}{l}\text { Inhalation of } \\
\text { spilled soil }\end{array}$ \\
\end{tabular} & - & - & - & - & - & - & - & - & - & - & - & - & - & - & - & - & - & - \\
\hline Water ingestion & 0.002 & 0.002 & 0.002 & 0.003 & 0.002 & 0.002 & - & 0.004 & 0.002 & - & 0.002 & 0.001 & 0.002 & 0.002 & 0.002 & 0.002 & 0.002 & 0.002 \\
\hline $\begin{array}{l}\text { Ingestion of } \\
\text { water (tritium) } \\
\end{array}$ & 0.003 & 0.004 & 0.004 & 0.004 & 0.004 & 0.03 & 0.009 & 0.007 & 0.005 & 0.002 & 0.002 & 0.004 & 0.004 & 0.004 & 0.004 & 0.004 & 0.003 & 0.004 \\
\hline Soil ingestion & - & - & - & - & - & - & - & - & - & - & - & - & - & - & - & - & - & - \\
\hline Total $^{\dagger}$ & 0.008 & 0.02 & 0.02 & 0.02 & 0.009 & 0.04 & 0.02 & 0.02 & 0.02 & 0.007 & 0.008 & 0.006 & 0.006 & 0.006 & 0.006 & 0.006 & 0.008 & 0.02 \\
\hline Upper-Bound & 0.08 & 0.2 & 0.2 & 0.2 & 0.09 & 0.4 & 0.2 & 0.2 & 0.2 & 0.07 & 0.08 & 0.06 & 0.06 & 0.06 & 0.06 & 0.06 & 0.08 & 0.2 \\
\hline \multicolumn{19}{|c|}{ Red Bone Marrow (rem*) } \\
\hline $\begin{array}{l}\text { Inhalation of } \\
\text { airborne } \\
\text { radioactivity } \\
\end{array}$ & - & - & - & - & - & - & - & - & - & - & - & - & - & - & - & - & - & - \\
\hline \begin{tabular}{|l|}
$\begin{array}{l}\text { Inhalation of } \\
\text { suspended soil }\end{array}$ \\
\end{tabular} & - & - & - & - & - & - & - & - & - & - & - & - & - & - & - & - & - & - \\
\hline \begin{tabular}{|l|} 
Inhalation of \\
spilled soil
\end{tabular} & - & - & - & - & - & - & - & - & - & - & - & - & - & - & - & - & - & - \\
\hline Water ingestion & 0.002 & 0.002 & 0.002 & 0.003 & 0.002 & 0.002 & - & 0.004 & 0.002 & - & 0.002 & 0.001 & 0.002 & 0.002 & 0.002 & 0.002 & 0.002 & 0.002 \\
\hline $\begin{array}{l}\text { Ingestion of } \\
\text { water (tritium) }\end{array}$ & 0.003 & 0.004 & 0.004 & 0.004 & 0.004 & 0.03 & 0.009 & 0.007 & 0.005 & 0.002 & 0.002 & 0.004 & 0.004 & 0.004 & 0.004 & 0.004 & 0.003 & 0.004 \\
\hline
\end{tabular}




\begin{tabular}{|c|c|c|c|c|c|c|c|c|c|c|c|c|c|c|c|c|c|c|}
\hline Pathway & DF62 & DF63 & DF64 & DF65 & DF66 & DF67 & DF68 & DF69 & DF70 & DF71 & DF72 & DF73 & DF74 & DF75 & DF76 & DF77 & DF78 & DF79 \\
\hline Soil ingestion & - & - & - & - & - & - & - & - & - & - & - & - & - & - & - & - & - & - \\
\hline Total $^{\dagger}$ & 0.004 & 0.006 & 0.006 & 0.007 & 0.006 & 0.03 & 0.01 & 0.02 & 0.006 & 0.002 & 0.003 & 0.005 & 0.006 & 0.006 & 0.006 & 0.006 & 0.004 & 0.006 \\
\hline Upper-Bound & 0.04 & 0.06 & 0.06 & 0.07 & 0.06 & 0.3 & 0.1 & 0.2 & 0.06 & 0.02 & 0.03 & 0.05 & 0.06 & 0.06 & 0.06 & 0.06 & 0.04 & 0.06 \\
\hline
\end{tabular}

*1 rem = $10 \mathrm{mSv}$, "-" means $<0.001$ rem

${ }^{\dagger}$ Total doses may not match the sum of pathway dose components because all results are rounded up to one significant digit.

Table 29. Internal doses and upper-bounds for austral summer support personnel

\begin{tabular}{|l|c|c|c|c|c|c|c|c|c|c|c|c|c|c|c|c|c|c|}
\hline Pathway & DF62 & DF63 & DF64 & DF65 & DF66 & DF67 & DF68 & DF69 & DF70 & DF71 & DF72 & DF73 & DF74 & DF75 & DF76 & DF77 & DF78 & DF79 \\
\hline
\end{tabular}

\begin{tabular}{|c|c|c|c|c|c|c|c|c|c|c|c|c|c|c|c|c|c|c|}
\hline \multicolumn{19}{|c|}{ Effective (Whole-Body) Dose (rem $\left.{ }^{*}\right)$} \\
\hline $\begin{array}{l}\text { Inhalation of } \\
\text { airborne } \\
\text { radioactivity }\end{array}$ & - & - & - & - & - & - & - & - & - & - & - & - & - & - & - & - & - & - \\
\hline $\begin{array}{l}\text { Inhalation of } \\
\text { suspended soil }\end{array}$ & - & - & - & - & - & - & - & - & - & - & - & - & - & - & - & - & - & - \\
\hline $\begin{array}{l}\text { Inhalation of } \\
\text { spilled soil }\end{array}$ & - & - & - & - & - & - & - & - & - & - & - & - & - & - & - & - & - & - \\
\hline Water ingestion & 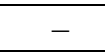 & - & - & 0.002 & 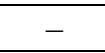 & 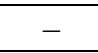 & - & 0.001 & 0.001 & - & - & 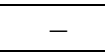 & - & - & 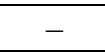 & - & - & - \\
\hline $\begin{array}{l}\text { Ingestion of } \\
\text { water (tritium) }\end{array}$ & 0.002 & 0.002 & 0.002 & 0.002 & 0.002 & 0.02 & 0.006 & 0.006 & 0.003 & - & - & 0.002 & 0.002 & 0.002 & 0.002 & 0.002 & 0.002 & 0.002 \\
\hline Soil ingestion & - & - & - & - & - & - & - & - & - & - & - & - & - & - & - & - & - & - \\
\hline Total $^{\dagger}$ & 0.003 & 0.003 & 0.003 & 0.003 & 0.003 & 0.02 & 0.006 & 0.007 & 0.004 & 0.002 & - & 0.002 & 0.003 & 0.004 & 0.004 & 0.004 & 0.004 & 0.004 \\
\hline Upper-Bound & 0.03 & 0.03 & 0.03 & 0.03 & 0.03 & 0.2 & 0.06 & 0.07 & 0.04 & 0.02 & 0.009 & 0.02 & 0.03 & 0.04 & 0.04 & 0.04 & 0.04 & 0.04 \\
\hline \multicolumn{19}{|c|}{ Thyroid (rem*) } \\
\hline $\begin{array}{l}\text { Inhalation of } \\
\text { airborne } \\
\text { radioactivity }\end{array}$ & 0.002 & 0.003 & 0.003 & 0.003 & 0.002 & 0.003 & 0.003 & 0.003 & 0.002 & 0.002 & 0.003 & - & - & - & - & - & - & 0.002 \\
\hline $\begin{array}{l}\text { Inhalation of } \\
\text { suspended soil }\end{array}$ & - & - & - & - & - & - & - & - & - & - & - & - & - & - & - & - & - & - \\
\hline $\begin{array}{l}\text { Inhalation of } \\
\text { spilled soil }\end{array}$ & - & - & - & - & - & - & - & - & - & - & - & - & - & - & - & - & - & - \\
\hline Water ingestion & 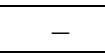 & $\begin{array}{llll}- & \\
\end{array}$ & 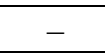 & 0.002 & 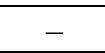 & 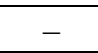 & 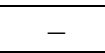 & 0.001 & 0.001 & 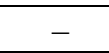 & 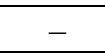 & 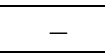 & 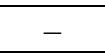 & 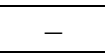 & 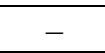 & 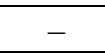 & 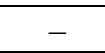 & 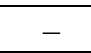 \\
\hline $\begin{array}{l}\text { Ingestion of } \\
\text { water (tritium) }\end{array}$ & 0.002 & 0.002 & 0.002 & 0.002 & 0.002 & 0.02 & 0.006 & 0.005 & 0.003 & - & - & 0.002 & 0.002 & 0.002 & 0.002 & 0.002 & 0.002 & 0.002 \\
\hline Soil ingestion & - & - & - & - & - & - & - & - & - & - & - & - & - & - & - & - & - & - \\
\hline Total $^{\dagger}$ & 0.004 & 0.005 & 0.005 & 0.005 & 0.004 & 0.02 & 0.008 & 0.009 & 0.005 & 0.003 & 0.003 & 0.003 & 0.003 & 0.004 & 0.004 & 0.004 & 0.004 & 0.004 \\
\hline Upper-Bound & 0.04 & 0.05 & 0.05 & 0.05 & 0.04 & 0.2 & 0.08 & 0.09 & 0.05 & 0.03 & 0.03 & 0.03 & 0.03 & 0.04 & 0.04 & 0.04 & 0.04 & 0.04 \\
\hline
\end{tabular}




\begin{tabular}{|c|c|c|c|c|c|c|c|c|c|c|c|c|c|c|c|c|c|c|}
\hline Pathway & DF62 & DF63 & DF64 & DF65 & DF66 & DF67 & DF68 & DF69 & DF70 & DF71 & DF72 & DF73 & DF74 & DF75 & DF76 & DF77 & DF78 & DF79 \\
\hline \multicolumn{19}{|c|}{ Red Bone Marrow (rem) } \\
\hline $\begin{array}{l}\text { Inhalation of } \\
\text { airborne } \\
\text { radioactivity }\end{array}$ & - & - & - & - & - & - & - & - & - & - & - & - & - & - & - & - & - & - \\
\hline $\begin{array}{l}\text { Inhalation of } \\
\text { suspended soil }\end{array}$ & - & - & - & - & - & - & - & - & - & - & - & - & - & - & - & - & - & - \\
\hline $\begin{array}{l}\text { Inhalation of } \\
\text { spilled soil }\end{array}$ & - & - & - & - & - & - & - & - & - & - & - & - & - & - & - & - & - & - \\
\hline Water ingestion & - & - & - & 0.002 & - & - & - & 0.001 & 0.001 & - & - & - & - & - & - & - & - & - \\
\hline $\begin{array}{l}\text { Ingestion of } \\
\text { water (tritium) }\end{array}$ & 0.002 & 0.002 & 0.002 & 0.002 & 0.002 & 0.02 & 0.006 & 0.005 & 0.003 & - & - & 0.002 & 0.002 & 0.002 & 0.002 & 0.002 & 0.002 & 0.002 \\
\hline Soil ingestion & - & - & - & - & - & - & - & - & - & - & - & - & - & - & - & - & - & - \\
\hline Total $^{\dagger}$ & 0.003 & 0.003 & 0.003 & 0.003 & 0.003 & 0.02 & 0.006 & 0.006 & 0.004 & 0.002 & - & 0.002 & 0.003 & 0.004 & 0.004 & 0.004 & 0.004 & 0.003 \\
\hline Upper-Bound & 0.03 & 0.03 & 0.03 & 0.03 & 0.03 & 0.2 & 0.06 & 0.06 & 0.04 & 0.02 & 0.008 & 0.02 & 0.03 & 0.04 & 0.04 & 0.04 & 0.04 & 0.03 \\
\hline
\end{tabular}

* 1 rem = $10 \mathrm{mSv}$, "-" means <0.001 rem

${ }^{\dagger}$ Total doses may not match the sum of pathway dose components because all results are rounded up to one significant digit. 
Table 30. Upper-bound external, internal, and total doses for McMurdo Station support personnel during Deep Freeze years 1962 to 1979

\begin{tabular}{|c|c|c|c|c|}
\hline \multirow[t]{2}{*}{$\begin{array}{c}\text { Reported } \\
\text { Period }\end{array}$} & \multirow[t]{2}{*}{$\begin{array}{c}\text { Effective Dose } \\
\text { or } \\
\text { Organ }\end{array}$} & \multicolumn{2}{|c|}{$\begin{array}{c}\text { Range of } \\
\text { Upper-Bound Doses } \\
\text { (rem (mSv)) }\end{array}$} & \multirow[t]{2}{*}{$\begin{array}{c}\text { Range of } \\
\text { Upper-Bound Total Doses } \\
(\text { rem }(\mathrm{mSv}))^{*}\end{array}$} \\
\hline & & External & Internal & \\
\hline \multirow{3}{*}{ Winter-over } & Effective dose & $\begin{array}{c}0.2-0.4 \\
(2-4)\end{array}$ & $\begin{array}{c}0.03-0.4 \\
(0.3-4)\end{array}$ & $\begin{array}{c}0.2-0.6 \\
(2-6)\end{array}$ \\
\hline & Thyroid & $\begin{array}{c}0.2-0.4 \\
(2-4)\end{array}$ & $\begin{array}{c}0.06-0.4 \\
(0.6-4)\end{array}$ & $\begin{array}{c}0.2-0.6 \\
(2-6)\end{array}$ \\
\hline & Red bone marrow & $\begin{array}{c}0.2-0.4 \\
(2-4)\end{array}$ & $\begin{array}{c}0.02-0.3 \\
(0.2-3)\end{array}$ & $\begin{array}{c}0.2-0.6 \\
(2-6)\end{array}$ \\
\hline \multirow{3}{*}{$\begin{array}{l}\text { Austral } \\
\text { summer }\end{array}$} & Effective dose & $\begin{array}{c}0.2-0.3 \\
(2-3)\end{array}$ & $\begin{array}{c}0.009-0.2 \\
(0.09-2)\end{array}$ & $\begin{array}{c}0.2-0.4 \\
(2-4)\end{array}$ \\
\hline & Thyroid & $\begin{array}{c}0.2-0.3 \\
(2-3)\end{array}$ & $\begin{array}{c}0.03-0.2 \\
(0.3-2)\end{array}$ & $\begin{array}{c}0.2-0.4 \\
(2-4)\end{array}$ \\
\hline & Red bone marrow & $\begin{array}{c}0.2-0.3 \\
(2-3)\end{array}$ & $\begin{array}{c}0.008-0.2 \\
(0.08-2)\end{array}$ & $\begin{array}{c}0.2-0.4 \\
(2-4)\end{array}$ \\
\hline
\end{tabular}

* The upper-bound total doses are not the sum of the corresponding external and internal doses in this table. The minimum and maximum values for the upper-bound external and internal doses do not correspond to the same period (winter-over or summer); whereas, the total doses are combined from external and internal doses from the same winter-over or summer period. In addition, results are rounded up to one significant digit.

\subsection{Comparative Radiation Exposures in Daily Life}

To understand the relative magnitude of the maximum total effective doses listed in Table 26 through Table 30, these doses can be compared to those from exposures to radiation that are common to most veterans and the general public. Table 31 lists various sources of radiation exposures in daily life (NCRP, 2009). Table 32 lists common diagnostic radiological exams and the doses that a patient receives from those exams (Mettler et al., 2008; NCRP, 2009).

A comparison of doses shows that the estimated dose from immersion in an Ar-41 cloud from the NPP is much higher than at similar reactors. For example, the annual Ar-41 immersion dose for the University of Wisconsin TRIGA research reactor in Madison, WI, has been estimated to be less than $0.001 \mathrm{rem}(0.01 \mathrm{mSv}$ ) (USNRC, 2012a). The Ar-41 immersion dose for the TRIGA reactor at Washington State University in Pullman, WA, has been estimated to be less than $0.0001 \mathrm{mrem}(0.001 \mathrm{mSv}$ ) (USNRC, 2011b). The calculated doses due to immersion in a cloud of Ar-41 are much higher at McMurdo Station due to the high-sided assumptions used and the NPP operating a higher percentage of the time versus a research nuclear reactor on a university campus. 
Table 31. Doses from radiation in daily life

\begin{tabular}{|l|c|}
\hline \multicolumn{1}{|c|}{ Description } & \multicolumn{1}{|c|}{$\begin{array}{c}\text { Effective Dose } \\
\text { (rem (mSv)) }\end{array}$} \\
\hline Upper limit of radiation dose permitted for radiation workers & $5(50)$ per year \\
\hline $\begin{array}{l}\text { Radiation dose from naturally occurring radioactive material in } \\
\text { Guaparai, Brazil (One of the highest background radiation } \\
\text { locations in the world) }\end{array}$ & $1(10)$ per year \\
\hline $\begin{array}{l}\text { Natural radiation dose per year (U.S. average) } \\
\text { External: } \\
\text { Space (cosmic ray): 0.033 rem } \\
\text { Terrestrial: 0.021 rem }\end{array}$ & \\
$\begin{array}{l}\text { Internal: } \\
\text { Ingestion: 0.029 rem } \\
\text { Inhalation (Radon): 0.228 rem }\end{array}$ & $0.31(3.1)$ per year \\
\hline Dose limit for public (except for medical care) & \\
\hline $\begin{array}{l}\text { A round-trip flight between Los Angeles and New York (dose } \\
\text { due to increased cosmic radiation at high altitude) }\end{array}$ & $<0.1(1)$ per year \\
\hline Average annual dose around a nuclear plant & $<0.01(<0.1)$ per year \\
\hline $\begin{array}{l}\text { Evaluated dose of radiation from radioactive substances } \\
\text { emitted from a nuclear fuel reprocessing plant per year }\end{array}$ & $<0.01(<0.1)$ per year \\
\hline
\end{tabular}

Table 32. Doses from radiological exams

\begin{tabular}{|l|l|}
\hline \multicolumn{1}{|c|}{ Examinations and Procedures } & \multicolumn{1}{c|}{$\begin{array}{c}\text { Effective Dose } \\
\text { (rem (mSv)) }\end{array}$} \\
\hline \multicolumn{2}{|c|}{ Fluoroscopic x-ray examination } \\
\hline Upper gastro-intestinal & $0.6(6)$ \\
\hline Barium enema Computed tomography examination \\
\hline \multicolumn{2}{|c|}{$0.7(7)$} \\
\hline Head & $0.2(2)$ \\
\hline Chest & $0.7(7)$ \\
\hline Abdomen/pelvis & $1.0(10)$ \\
\hline Whole-body screening & $1.0(10)$ \\
\hline Biopsy & $0.1(1)$ \\
\hline \multicolumn{2}{|c|}{ Conventional x-ray examination } \\
\hline Chest & $0.01(0.1)$ \\
\hline Cervical spine & $0.02(0.2)$ \\
\hline Thoracic spine & $0.1(1)$ \\
\hline Lumbar spine & $0.15(1.5)$ \\
\hline Pelvis & $0.07(0.7)$ \\
\hline Abdomen or hip & $0.06(0.6)$ \\
\hline
\end{tabular}




\subsection{Potential Health Effects}

The maximum total upper-bound equivalent dose (external and internal combined) for McMurdo Station support personnel for the organs considered is 0.6 rem $(6 \mathrm{mSv})$ for any tour. The maximum total upper-bound equivalent dose is the thyroid dose that veterans accrued during winter-over DF 67. The total upper-bound equivalent dose for the red bone marrow was calculated to be 0.5 rem ( $5 \mathrm{mSv}$ ) for any tour. The doses to all other organs would be similar to the red bone marrow because the dose coefficients are comparable/similar. These organ doses are low and the associated probability that disease could have arisen from these doses is also low. For comparison, at effective doses less than 5 to 10 rem (50 to $100 \mathrm{mSv}$ ), risks of health effects are either too small to be observed or nonexistent (HPS, 2010).

The doses listed above are well below the level that would cause any deterministic health effects (health effects caused by cell death, e.g., cataracts, skin burns, etc.). For comparison, the dose limit for radiation workers of 5 rem $(50 \mathrm{mSv})$ per year shown in the Table 31 above is intended to be protective against deterministic effects.

To determine the potential for stochastic effects (health effects that are random or probabilistic in nature where their occurrence cannot be predicted, e.g., a cancer), the upperbound doses can be compared to screening doses. The screening doses are equivalent doses to the organ or tissue in which the cancer type occurs that are intended to correspond to a probability of causation of 50 percent at an upper credibility limit of 99 percent. The lowest screening doses for any organ for which a solid tissue cancer can develop is for cancers of the thyroid, liver, or gall bladder that may develop at 10 or more years after exposure. (Kocher and Apostoaei, 2007)

The maximum calculated total upper-bound dose thyroid dose of 0.6 rem for the support personnel who were stationed at McMurdo from 1962 to 1979 is well below the screening dose of 7.5 rem for cancers of the thyroid, and the maximum calculated total upper-bound doses of 0.6 rem for liver, gall bladder, and red bone marrow are well below the screening doses of 4.0 rem, 6.0 rem, and 4.4 rem for cancers of the liver, gall bladder, and red bone marrow (leukemia), respectively. Therefore, it can be concluded that the maximum total upper-bound organ doses for support personnel at McMurdo Station have associated probabilities of causation that are far less than 50 percent for any cancers that might arise in McMurdo veterans. Because all other organs have higher screening doses and lower expected total upper-bound organ doses than those for the thyroid, liver, gall bladder and red bone marrow, it follows that the probability of causation for cancer of any of the other organs would be much less than 50 percent. The screening doses for all organ considered are reported in Kocher and Apostoaei (2007). 


\section{7.}

\section{Radiation Dose Assessment for Reactor and Decommissioning Crew Members}

Reactor and decommissioning crew members were exposed to sources of external and internal radiation while working at the McMurdo Station NPP either during reactor operations or during decommissioning. In addition, reactor crew members would have been exposed to sources while outside of the NPP and while off-duty that were similar to the exposures of support personnel. Records show that some crew members who were at the NPP during operational years also participated in the decommissioning.

The compiled gamma radiation dosimetry records for reactor crew members for DF years for which dosimetry results were located are summarized in Table 5. Since reactor crew members wore dosimeters that only recorded external doses and had diverse exposure scenarios, the total upper-bound doses that include internal doses cannot be estimated generically. Dose assessments for these individuals should be performed in accordance with the proposed procedure guidelines described in Section 8. This section provides information on sources of radiation exposure and pathways needed to support individualized dose assessments for reactor and decommissioning crew members.

\subsection{Sources of External Radiation Exposure}

\subsubsection{Reactor Crew Members during NPP Operation}

\subsubsection{Radiation Sources at the NPP Facility while on Duty}

The reactor crew members who worked at the NPP were exposed to external gamma and neutron radiation from sources inside and outside the facility. The following sources of potential exposure to external radiation are applicable for reactor personnel during the operational years of the NPP while on duty: the reactor, contaminated reactor facility components and equipment, radioactive waste, packages containing radioactive materials, radioactive gases, and radioactive contamination in the effluent discharge area and NPP yard.

While on duty, each reactor crew member was monitored for external gamma and neutron exposures with an individual film badge. For certain periods, TLDs were issued in addition to film badges. The film badges were exchanged and processed monthly whereas the TLDs were worn for the entire tour before processing (Johnson, 1971).

\subsubsection{Radiation Sources while off Duty}

Reactor crew members could have been exposed to external gamma radiation when transiting near the NPP fence line, such as hiking on Observation Hill, driving, or walking while 
off-duty. Reactor crew members would have also been exposed to gamma radiation from immersion in clouds of radioactive noble gases such as Ar-41. They are assumed to have not been wearing their dosimeters while off-duty (Armstrong, 2012).

\subsubsection{Decommissioning Crew Members}

\subsubsection{Radiation Sources at the NPP Facility while on Duty}

The decommissioning crew members who worked mainly inside the NPP were exposed to external gamma radiation from sources inside and outside the facility. The following sources

of potential exposure to external radiation while on duty are applicable for crew members during the decommissioning period of the NPP: spent reactor cores, components and equipment contaminated with residual radioactive materials, radioactive waste, radioactive waste packages, radioactive contamination in the effluent discharge areas and the NPP yard, and bulk contaminated soil during movement of the soil.

While on duty, external gamma doses of decommissioning crew members were monitored with individually issued film badges. For certain periods, TLDs were issued in addition to film badges. The film badges were exchanged and processed monthly (Johnson, 1971). The TLD exchange period is not known.

\subsubsection{Radiation Sources while off Duty}

Decommissioning crew members could have received external gamma radiation doses while hiking, driving, or walking close to the NPP fence. In addition, they could have been exposed to residual contamination in soil spilled during transport and ship loading. The crew members are assumed to have not been wearing their dosimeters while off-duty. (Armstrong, 2012)

\subsection{Sources of Internal Radiation Exposure}

\subsubsection{Reactor Crew Members during NPP Operation}

\subsubsection{Inhalation of Airborne Radioactive Materials while inside the NPP}

Reactor crew members could have inhaled airborne radioactive materials while working inside the NPP. The potential sources of airborne radioactivity include radioactive gases and airborne particulates coming from the containment purging system, the radioactive waste disposal system, the primary sampling system, the chemistry laboratory, the decontamination pad, and the primary building and primary building addition (NNPU, 1967). Entry into areas with airborne radioactive materials would have been controlled using the radiation work permit process (Martin Company, 1964).

\subsubsection{Inhalation of Airborne Radioactive Materials while outside the NPP}

Reactor crew members could have inhaled airborne radioactive effluents to include gases and aerosols released from the main stack of the NPP and from worldwide fallout. The inhalation 
could have occurred during off-duty time and would have occurred in areas outside the NPP (Foster and Jones, 1982).

\subsubsection{Ingestion of Drinking Water}

Reactor crew members could have ingested radioactive materials in the drinking water at McMurdo Station. The drinking water could have contained radioactive materials released from the NPP to include tritium and other long-lived beta emitters. Also, drinking water could have contained traces of naturally-occurring radioactive materials and radioactive fallout from atmospheric testing of nuclear weapons (Foster and Jones, 1982).

\subsubsection{Decommissioning Crew Members}

\subsubsection{Inhalation of Airborne Radioactive Materials while on Duty}

Crew members could have inhaled airborne radioactive material during the decommissioning of the NPP. Such inhalation could have occurred during facility decontamination, equipment disassembly, and building dismantling. Crew members could have inhaled suspended contaminated soil during surveys, excavation, and decontamination of the effluent discharge areas and the NPP yard. In addition, crew members could have inhaled suspended soil contaminated with radioactive materials during transportation of bulk soil to the ship loading area and while loading the ships. Also, the air could have contained traces of naturally occurring radioactive materials and radioactive fallout from atmospheric testing of nuclear weapons. (Foster and Jones, 1982)

\subsubsection{Inhalation of Airborne Radioactive Materials while off Duty}

Crew members could have inhaled residual radioactive material in suspended contaminated soil left over after ship loading or spilled onto the roads leading to the ship loading area. The inhalation would have occurred while off duty in addition to exposures while on duty.

\subsubsection{Ingestion of Drinking Water}

Crew members could have ingested radioactive materials in the drinking water during the decommissioning phase of the NPP. The drinking water could have contained tritium and radioactive materials released from the NPP. Also, drinking water could have contained traces of naturally occurring radioactive materials and radioactive fallout from atmospheric testing of nuclear weapons. (Foster and Jones, 1982)

\subsubsection{Incidental Ingestion of Contaminated Soil and Dust}

Decommissioning crew members could have incidentally ingested soil and dust contaminated with radioactive materials. The contaminated soil would have been disturbed and spread during decommissioning operations such as demolition work, soil excavation, surveys, transportation of bulk soil to the ship loading areas, and ship loading (Foster and Jones, 1982). In addition, crew members could have incidentally ingested residual soil contaminated with radioactive materials that was left over in the ship loading area or spilled onto the roads leading to the ship loading area (NNPU, 1976). 


\subsection{Dose Estimation Methodology}

\subsubsection{External Dose}

An external dose assessment for individual reactor crew members, including decommissioning personnel, requires film badge results. Since doses among the members of the reactor crews varied with length of tour, year(s) of assignment, and specific duties, generic external doses for these cohorts cannot be estimated.

If individual film badge records cannot be located for an individual reactor crew member, dosimetry for other crew members who were at McMurdo Station during the same time and who served in similar positions could be used as surrogate (cohort) data (DTRA, 2010, Standard Method ED01).

A further complication for individual dose assessments for crew members is that many of them were assigned to other reactors or other locations with potential exposures to external radiation during the same calendar years that they were assigned to McMurdo Station. The potential sources of exposures at other reactors or facilities could be different than the sources of exposure at McMurdo Station, and could have been combined with McMurdo Station exposures in their dosimetry records.

It is assumed that reactor personnel did not wear their badges while off duty. Therefore, the external doses for off work time while outside the NPP are similar to the external dose estimates for support personnel, which are addressed earlier in the report.

\subsubsection{Inhalation of Airborne Radioactive Materials}

Detailed air monitoring records and records of respiratory protection measures would normally be used to reconstruct the internal exposure from inhalation of radioactive materials. Although air monitoring data were typically collected for operational purposes, these data were not archived and are not available. Some air monitoring results have been located for operations involving removal of contaminated soil and rock from the reactor facility, storage yard, areas adjacent to the NPP, and effluent discharge areas. However, the air monitoring results are not sufficient to form the primary basis of an inhalation dose reconstruction (NNPU, 1976; NNPU, 1977b).

An internal dose assessment for individual reactor crew members would require internal monitoring results. Since internal doses from inhalation of radioactive materials while at the NPP would have varied among the members of the reactor crews because of differences in length of tour, DF year(s) of assignment, and specific duties, a generic internal inhalation dose cannot be estimated. Therefore, if individual internal monitoring results cannot be located for a reactor crew member, internal monitoring results for other crew members who were at McMurdo Station during the same time and who served in similar positions could be used as surrogate data.

Two complications arise from using internal monitoring results from whole-body counting. First, since whole-body counting measures the internal deposition of long-lived gamma-ray emitters, it does not distinguish between inhaled or ingested radioactive materials. Also, whole-body counting does not distinguish between an intake during work inside the NPP or off-duty outside the NPP. Furthermore, many of the reactor crew members were assigned to 
other reactors or other locations where they had the potential for the intake of radioactive materials during the same calendar year(s) as their tours at McMurdo Station.

The inhalation doses that a reactor crew member would have received while off duty and while outside the NPP would have been similar to the McMurdo Station support personnel. However, the dose from any airborne long-lived gamma-ray emitters and the Cs-137 in contaminated soil inhaled while off duty would be reflected in any individual internal monitoring results.

\subsubsection{Ingestion of Radioactive Materials}

The ingestion doses due to short-lived radioactive isotopes and tritium are generally not reflected in internal monitoring results obtained using a whole-body counter, which cannot detect tritium's low-energy beta particle radiations (Cember, 1983). Those doses would need to be estimated using dose reconstruction methods and added to the doses determined from internal monitoring results.

For long-lived gamma emitting radioisotopes, dose assessments for individual reactor crew members would require individual internal monitoring results. Internal monitoring results from whole-body counts would measure the internal deposition of radioactive materials from both inhalation and ingestion. 


\section{8. \\ Recommendations for Radiogenic Disease Claim Process}

\subsection{Guidance for the Radiogenic Disease Claim Process}

The Department of Veterans Affairs (VA) offers health registry exams, health care, disability compensation and other benefits to eligible veterans for diseases caused by exposure to radiation. Their dependents and survivors also may be eligible for benefits.

The following is provided to assist veterans who believe that they have a disease or ailment caused by possible exposure to ionizing radiation at McMurdo Station from the NPP between 1962 and 1979. For more information on how to submit a claim for radiogenic diseases, visit the U.S. Department of Veterans Affairs at the following webpages:

a) Understanding the Disability Claims Process:

http://www.vba.va.gov/bln/21/Topics/claims.htm

b) Disability Compensation for Radiation-Related Disease:

http://www.publichealth.va.gov/exposures/radiation/benefits/index.asp

\subsubsection{For McMurdo Station Veterans who are First Time Filers}

First-time filers, who are veterans claiming VA health care, benefits and disability compensation for a radiogenic disease arising from exposure to radiation from the NPP while on active duty service at McMurdo Station, should take the following steps:

- Complete a VA Form 21-526, Veterans Application for Compensation and/or Pension, and attach the following:

- Discharge or separation papers (DD214 or equivalent)

- Medical evidence (doctor and hospital reports)

- $\quad$ Dependency records if applying as dependent or survivor (marriage and children's birth certificates)

- This documentation can be submitted online or via a local VA Regional Office (VARO)

- For assistance, call toll-free: (800) 827-1000 
Veterans may also fill out a disability compensation application online at:

http://vabenefits.vba.va.gov/vonapp/.

Alternatively, veterans may print and mail-in Form 21-526 or call the VA at (800) 827-1000 to ask to have the form mailed to them.

\subsubsection{For McMurdo Station Veterans Previously Denied VA Service Connection}

Veterans previously denied VA service connection for disability compensation due to radiogenic disease arising from active duty service at McMurdo Station may re-file based on new information presented in this technical report. The veteran should contact their VA Regional Office and request that the claim for service connection be reopened. The veteran should cite this technical report, DTRA-TR-12-003(R1), as the basis for the request to reopen the claim, i.e., new and material evidence.

\subsubsection{For a Surviving Spouse of a Deceased McMurdo Station Veteran}

The surviving spouse of a deceased McMurdo Station veteran should complete a VA Form 21-534 for an original claim. If an original claim has been filed in the past, and denied, then the surviving spouse can reopen the previously denied claim by submitting the basis for new evidence, i.e., cite this technical report (DTRA-TR-12-003(R1)).

\subsubsection{For the Veterans Benefits Administration (VBA)}

The VBA has centralized the processing of radiogenic disease claims at VARO Jackson, MS (VBA, 2006).

- Upon receipt of a McMurdo Station veteran claim for radiogenic disease, VARO Jackson should request that the veteran complete a McMurdo Station Radiation Exposure Questionnaire (see Appendix C).

- Upon receipt of a completed questionnaire, forward a request to Naval Dosimetry Center for the veteran's occupational radiation exposure records.

- Upon receipt of the Naval Dosimetry Center response, VARO Jackson should submit the records to the Under Secretary for Benefits (Director, Compensation Service), for review. The Under Secretary for Benefits may request an advisory medical opinion from the Under Secretary for Health (Director, Environmental Agents Service). 


\subsubsection{For Director, Environmental Agents Service, Veterans Health Administration (VHA)}

Use the scenarios and doses cited in DTRA-TR-12-003(R1) as guidance in performing medical opinions. Chief, Nuclear Test Personnel Review, DTRA is available for technical consultation.

\subsubsection{For the Naval Dosimetry Center}

Upon receipt of VARO Jackson's request for a McMurdo Station veteran's radiation exposure records, first verify if occupational radiation exposure records exist for the veteran. Then ensure a complete radiation dose assessment using the guidelines with Section 8.2. The radiation dose evaluation would include information from any pertinent veteran occupational exposure records. Upon completion of this assessment, forward results to VARO Jackson.

\subsection{Proposed Guidelines for Individual Radiation Dose Assessment for McMurdo Station Veterans}

The following is provided as guidelines that should be used to create detailed procedures for performing individual radiation dose assessment for McMurdo Station veterans.

\subsubsection{Assignment to Appropriate Group and Collection of Information}

Veterans of military service at the McMurdo Station are characterized by two groups of exposure scenarios: (1) reactor and decommissioning crew members of the NPP, and (2) McMurdo Station support personnel.

The first step in performing an individual dose assessment is to determine the veteran's group. A recommended McMurdo Station questionnaire is included in Appendix C as a starting point in determining the group to which the veteran belongs.

The next step is to gather veteran-specific information about his or her participation in Operation Deep Freeze at McMurdo Station. The veteran's personnel and medical records from the National Personnel Records Center, St Louis, MO, should be obtained and reviewed. Additional information should be collected based on the records reviewed from other official records. The veteran should be given the opportunity to provide additional input. This would be in the form of a questionnaire or other statements based on his or her recollection. Veterans should also be requested to submit any documentation in their possession that contains information about their time at McMurdo Station.

\subsubsection{Individual Dose Assessment for Support Personnel}

Based on the veteran's recollection and an analysis of relevant individual data and historical record, a scenario of participation and radiation exposure (SPARE) would be developed to include the veteran's relevant activities and all possible exposure sources and pathways. The evaluation of exposure to radiation should be based on the pathways identified and assessed in this report. The dose calculations for each previously analyzed exposure pathway 
would then be adjusted to account for veteran-specific information. Changes to the standard calculations should only be considered if the adjustment to an exposure pathway results in a higher overall dose. An example of a potential adjustment to a known exposure pathway that may result in a higher overall dose would be for someone with duties that required visiting the NPP several times.

Additional sources of exposure for some McMurdo Station support personnel might need to be added to the exposure pathways already identified in this report. Such exposure pathways could include occupational exposure to x-ray radiation for individuals assigned to the health clinic or dental clinic (NDC, 1962-1979). Others could have assisted civilian researchers in experiments that included the use of radioactive materials such as described in the turn-in of radioactive waste to the facility (NNPU, 1977b).

If additional sources of exposures are identified, those specific doses should be calculated using standard dose reconstruction techniques such as those used in the NTPR program (DTRA, 2010) or equivalent approved procedures. An upper-bound total external dose and total internal dose would then need to be estimated using the dose calculation methods provided in Appendix B.

\subsubsection{Individual Dose Assessment for Reactor Crew Members}

Based on a reactor or decommissioning crew member's records and personal recollection along with historical records, a scenario of participation and radiation exposure (SPARE) would be developed to include the veteran's relevant activities and all possible exposure sources and pathways. A dose for each source and pathway would then be calculated.

Members of reactor crews were monitored for radiation exposure using film badges, TLDs, whole body counting, and possibly other measuring devices. Therefore, doses from some of the exposure pathways would be based on individual monitoring records. The doses for sources and pathways not reflected in individual monitoring results would be estimated using dose reconstruction techniques (DTRA, 2010).

Currently, sufficient in-plant monitoring and survey data have not been found to allow for the reconstruction of doses from internal exposure pathways for reactor crew members. Since their duties varied widely and historical records are limited, the reconstruction of doses from the intakes of radioactive material will need to be based on the veteran's internal monitoring records and bioassay results. When individual monitoring records are not available, appropriate surrogate data can be used.

Several types of individual monitoring records exist that could be used for an individual dose assessment. A veteran's record of occupational exposure can be found at the Naval Dosimetry Center or the Army Dosimetry Center. Also, a veteran's DD Form 1141 "Record of Occupational Exposure" that can be found in the veteran's medical record or in his or her possession can be used to supplement the individual dosimetry results from a service dosimetry center. Whole-body counting results can be found in the veteran's medical records or in his or her possession that could be used to determine the internal doses due to the intake of long-lived gamma emitters.

For those veterans whose film badge records cannot be located or who have gaps in their personal results, the dosimetry data of other veterans could be used as cohort dosimetry. The 
cohort film badge data would need to be from individuals who were assigned to the same tour who had the same or similar duties and military specialties. Since the film badge results would not be for the specific veteran, higher uncertainty factors should be used when calculating upperbound doses. (DTRA, 2010, Standard Method ED01 and UA01)

To determine the upper-bound external dose for an individual veteran, an uncertainty would be assigned to each film badge result. The upper-bound external dose would be calculated by combining the uncertainties of all film badge results following standard methods developed for the Nuclear Test Personnel Review Program or developed by the Navy (DTRA, 2010, Standard Method UA01; Blake, 2004).

To determine the internal dose for an individual veteran, procedures will need to be developed to use whole-body counting results to calculate committed effective doses or committed equivalent doses for the organs or tissues of interest. For example, the National Institute of Occupational Safety and Health (NIOSH) Dose Reconstruction Program uses the Integrated Modules for Bioassay Analysis (IMBA) software application to model input data that would produce whole body count equivalent results. IMBA has the capability of using input data like whole body counting results to determine intakes and internal doses to the organs of interest. (Brackett et al., 2008)

For a veteran whose whole-body counting results cannot be found or who did not receive a whole-body measurement upon returning to the U.S., other whole-body counting results can be used. The cohort monitoring data would need to be from the same DF year and from veterans with similar duties and military specialties.

Some radiation exposure pathways for reactor crew members were not monitored or accounted for by the veteran's film badge records or whole-body counting results. These unmonitored doses could require a dose estimation based on existing measurement data. Examples of such doses are immersion in a cloud of noble gas or inhalation of airborne radioactive iodine or ingestion of tritium in the drinking water. However, such unmonitored doses are likely to be similar to the corresponding doses calculated for support personnel.

A complicating factor for dose reconstructions of reactor crew members who served at McMurdo Station is that many of them received radiation doses at other nuclear facilities during the same calendar years. Many veterans received training on the PM-1A at Fort Belvoir before being assigned to the McMurdo Station NPP. In addition, after leaving McMurdo Station, several returned to the PM-1A or were assigned to other military NPPs. 


\section{9.}

\section{Conclusions}

\subsection{Summary of Assessment Approach}

The main goal of the radiation dose assessment documented in this report was to estimate conservative upper-bound external and internal radiation doses for McMurdo Station support personnel. The goal was met by accomplishing the steps described below.

Operating histories, operator's manuals, health physics logs, radioactive waste disposal documents, decommissioning reports, and other available records were reviewed. These historical records were used to develop a detailed description of the installation, operations, and decommissioning of the McMurdo Station NPP. In addition, all documented incidents and unusual deviations to normal operations at the NPP were reviewed.

Information was collected from U.S. Navy historical archives; verbal and written comments from veterans of McMurdo Station; and other governmental, historical, and academic sources. Information was located on environmental monitoring at McMurdo Station, on incidents and accidents that occurred, and on the radiation safety procedures that were followed. Reports were located on the results of the decommissioning efforts, the amount and types of radioactive waste generated during decommissioning, and the final radiological conditions at McMurdo Station.

External dosimetry results for Operation Deep Freeze 62 through 74 were located for reactor crew members. External dosimetry results were located for both winter-over and austral summer personnel. Internal monitoring results were located for several reactor crew members. In addition, environmental monitoring data based on dosimeter measurements during decommissioning were found and evaluated.

Seven potential sources of external exposure were identified to include the reactor, radioactive waste, radioactive effluent, radioactive materials in passing plumes, and contaminated soil deposited on the ground. Six potential sources of internal exposure were identified to include radioactive materials deposited in the tissues and organs after breathing air and ingesting water and soil and dust that contained radioactive material. The potential sources of both internal and external exposure were reviewed for any possible differences between winter-over and austral summer personnel. Where specific information on a potential source of exposure was unavailable, other methods of dose estimation, such as the use of surrogate data, were employed.

Using high-sided, conservative assumptions, both from exposure and contamination conditions that could have existed, radiation dose estimates were calculated for the McMurdo Station support personnel for each DF year. The radiation doses were estimated for winter-over and austral summer support personnel separately. The total effective whole body doses and the total equivalent dose to the thyroid and red bone marrow were estimated for winter-over and 
austral summer tours for each DF year between 1962 and 1979. The thyroid and red bone marrow were considered the best representatives of the human body organs that might be affected by the NPP radiation sources.

\subsection{Dose Assessment Results and Health Risks}

The calculated upper-bound total effective doses for support personnel at the McMurdo Station for DF years 62 to 79 ranged from 0.2 to 0.6 rem (2 to $6 \mathrm{mSv}$ ) per winter-over or austral summer tour. The highest estimated upper-bound total effective dose of 0.6 rem $(6 \mathrm{mSv})$ for any single tour at McMurdo Station was observed for the winter-over personnel during DF 67. The highest upper-bound dose had the highest tritium ingestion dose due to the reported tritium levels measured in the drinking water. For all DF years, the austral summer personnel had estimated upper-bound total doses that are smaller than for the winter-over personnel for the same year.

The estimated upper-bound total equivalent doses of the support personnel ranged from 0.2 to 0.6 rem ( 2 to $6 \mathrm{mSv}$ ) for the thyroid and from 0.2 to $0.5 \mathrm{rem}$ ( 2 to $5 \mathrm{mSv}$ ) for the red bone marrow per winter-over or austral summer tour. The highest estimated upper-bound total equivalent doses for any single tour are for the winter-over personnel during DF 67. The highest estimated upper-bound total equivalent dose had the highest tritium ingestion dose. For all DF years, the austral summer support personnel had estimated upper-bound total equivalent organ doses that were smaller than the winter-over personnel for the same year.

The upper-bound total doses for the support personnel in all DF years are comparable to the doses that veterans would have received from medical diagnostic procedures or from other sources encountered during their lives after leaving McMurdo Station. These doses are similar in magnitude to those that a person residing in the United States would receive, on average, in one year from background or medical sources.

The calculated doses are low and the associated probability that disease could have arisen from these doses is also low. For comparison, at effective doses less than 5 to 10 rem (50 to $100 \mathrm{mSv}$ ), risks of health effects are either too small to be observed or are nonexistent (HPS, 2010).

All estimated doses and upper-bounds reported here are generic cohort doses that can be assigned to any McMurdo Station support personnel veteran who had activities and exposures covered in this assessment for the period between 1962 and 1979. However, some support personnel may have been exposed to additional or distinctly different sources of radiation. For these veterans, proposed guidelines are provided in Section 8 for performing individualized radiation dose assessments that would include exposure scenarios that were not evaluated in this report.

\subsection{Recommendations for Radiogenic Disease Claims Process}

Recommendations and guidance are provided in this report to assist the McMurdo Station veterans and their dependents, the Secretary of Veterans Affairs and the Naval Dosimetry Center in the radiogenic disease claims process. Guidance is provided to develop procedures that can be used to perform individual dose assessments for McMurdo Station veterans. Separate procedures are proposed for support personnel, and reactor and decommissioning crew members. 
Using the available historical information, occupational dosimetry results and exposure pathways identified in this report, individual dose assessment procedures are proposed. The individualized assessments should be based on the pathways identified in this report along with an individual's specific history. If additional sources of exposures are identified, those specific doses should be calculated using standard dose reconstruction techniques such as those used in the NTPR program. 


\section{0.}

\section{References}

ASF (Antarctic Support Force),1962-1974. Personnel Exposure to Ionizing Radiation Annual Reports. Antarctic Support Activities/Force, FPO San Francisco, CA.

ASN (E,I\&E) (Assistant Secretary of the Navy for Energy, Installations and Environment), 2011. Letter to Senator Blumenthal, CT, regarding McMurdo Station Radiation Personnel Exposures. Washington, DC. July 26.

ASTSWMO (Association of State and Territorial Solid Waste Management Officials), 2009. Lack of Tritium Exit Signs control and Contamination of Landfill Leachate. Washington, DC. July.

Armstrong, L., 2012. “Southern Exposure.” Fleet Reserve Association Today. January 2012: 1827.

Blake, P.K., 2004. The History of the Navy Personnel Dosimetry (1946-2004). U.S. Naval Dosimetry Center, Bethesda, MD.

Blumenthal, R. 2011. Letter to Assistant Secretary of the Navy for Energy, Installations, \& Environment concerning McMurdo Station Radiation Personnel Exposures, United States Senate, Washington, DC. July 13.

Brackett, E.M., Allen, D.E., Siebert, S.R., and LaBone, T.R., 2008. “Internal Dose Reconstruction under Part B of the Energy Employees Compensation Act,” Health Physics, 95(1): 69-80.

Brown, J.B., Storhok, V.W., and Gates, J.E., 1967. Post-Irradiation Examination of the PM-3A type 1 Serial 2 Core Part I. Post-Irradiation Examination of Fuel Tubes, Battelle Memorial Institute, Columbus, OH. February 28.

Brown, S., 2011. Letter to Secretary of Defense concerning McMurdo Station Radiation Personnel Exposures, United States Senate, Washington, DC. March 10.

Busdiecker, R.L., and Maxwell, B.W., 1964. Environmental Radiation Surveillance in the Antarctic. Natural Radiation Environment, pp. 873-83, Adams, JA. Lowder, WM. (eds.). University of Chicago Press, Chicago, IL. October 31.

Calvert Cliffs Nuclear Power Plant, 2010. Calvert Cliffs Nuclear Power Plant Effluent and Waste Disposal 2009 Annual Report. Calvert Cliffs Nuclear Power Plant, Lusby, MD.

Cassata, J., Falo, G., Rademacher, S., Alleman, L., Rosser, C., Dunavant, J., Case, D., Blake, P., 2012. Dose Assessments for Shore-Based Individuals in Operation Tomodachi, Revision 1. DTRA-TR-12-001(R1), Defense Threat Reduction Agency, Fort Belvoir, VA. December 31.

Cember, H., 1983. Introduction to Health Physics, $2^{\text {nd }}$ Edition. Pergamon Press, Elmsford, NY. 
Chandrasekaran, T., Lee, J.Y., Willis, C.A., 1985. Calculation of Releases of Radioactive materials in Gaseous and Liquid Effluents from Pressurized Water Reactors. NUREG001, Rev 1., Division of Systems Integration, Office of nuclear Reactor Regulation, U.S. Nuclear Regulatory Commission, Washington, DC. April.

DTRA (Defense Threat Reduction Agency), 2010. Standard Operating Procedures Manual for Radiation Dose Assessment, Revision 1.3/1.3a. DTRA-SOP-10-01, Defense Threat Reduction Agency, Fort Belvoir, VA. January 31/March 31.

DOE (Department of Defense), 2001. A Historical Report on the U. S. Highly Enriched Uranium Production, Acquisition, and Utilization Activities from 1945 through September 30, 1996, Revision 1. U.S. Department of Energy, National Nuclear Security Administration, Office of the Deputy Administrator for Defense Programs, Washington, DC. January.

Eckerman, K.F., and Ryman, J.C., 1993. External Exposure to Radionuclides in Air, Water, and Soil, Federal Guidance Report No. 12. EPA-402-R-93-081, Environmental Protection Agency, Washington, DC.

Fairchild, G.R., 2012a. Review of the Navy's PM-3A (McMurdo Sound Nuclear Reactor) Dose Reconstruction Effort. Presentation at the VBDR Annual Meeting, San Antonio, TX, March 23-24.

Fairchild, G.R., 2012b. Personal communication with Jason Dunavant, SAIC, April 4.

Fegley, C., 2012. Personal communication with Jason Dunavant, SAIC, January 31.

Foster, M.E., and Jones, G.M., 1982. History of the PM-3A Nuclear Power Plant, McMurdo Antarctica. Naval Energy and Environmental Support Activity, Port Hueneme, CA. December.

HPS (Health Physics Society), 2010. Radiation Risk in Perspective. Position Statement of the Health Physics Society, McLean, VA. July. (http://hps.org/documents/risk_ps010-2.pdf, accessed December 4, 2012)

ICRP (International Commission on Radiation Protection), 1991. 1990 Recommendations of the International Commission on Radiological Protection. ICRP Publication 60. Pergamon Press, Elmsford, NY.

ICRP (International Commission on Radiation Protection), 1994a. Human Respiratory Tract Model for Radiological Protection. ICRP Publication 66, Pergamon Press, Elmsford, NY.

ICRP (International Commission on Radiation Protection), 1994b. Dose Coefficients for Intakes of Radionuclides by Workers. ICRP Publication 68, Pergamon Press, Elmsford, NY.

Jentz, T. L., 1978. Radiological Survey of the PM-3A Site, Volume 1. NUS \#3162, Rockville, MD. June.

Johnson, T.L., 1971. Comparison of a LiF-Teflon TLD System with Film Badge at the PM-3a Reactor Facility McMurdo Station, Antarctica, Naval Research Laboratory Test and Evaluation Report 127. Naval Research Laboratory, Washington, DC. September.

Jones, C.G., 2005. “A review of the History of U.S. Radiation Protection Regulations, Recommendations, and Standards,” Health Physics, 88(2):105-124. 
Jordan, N.M., 1978. Re-Analysis of Antarctic Crushed Rock Samples and Inter-comparison between Crushed Rock Analysis. Memorandum for File 3223, U.S. Navy Civil Engineering Laboratory, Port Hueneme, CA. April 3.

Kocher, D.C. and Apostoaei, J.A., 2007. Screening Doses for Induction of Cancers Calculated with the Interactive RadioEpidemiological Program (IREP). DTRA-TR-07-4. Defense Threat Reduction Agency, Fort Belvoir, VA. March.

Kocher, D.C., 2009. Evaluation of Generic 3X Upper Bound Factor Used in Reconstructing External Gamma Doses to Military Participants at Atmospheric Nuclear Weapons Tests. DTRA-SOP-09-14, Defense Threat Reduction Agency, Fort Belvoir, VA. November 30.

Lazzara, M.A., 2006. A McMurdo Station, Antarctica Climatology with Special Emphasis on Fog. Antarctic Meteorological Research Center, University of Wisconsin, Madison, WI. April 1.

Martin Company, 1964. Technical Manual for PM-3A Navy Nuclear Power Plant, Health Physics and Water Chemistry Manual, Volume 1 of 1. Martin Company, Baltimore, MD. February 13.

Mettler, F.A., Huda, W., Yoshizumi, T.T., and Mahesh, M., 2008. "Effective Doses in Radiology and Diagnostic Nuclear Medicine: A Catalog,” Radiology, 248(1):254-263.

Montain, S.J., and Matthew E., 2010. Water Requirements and Soldier Hydration. Borden Institute, Washington, DC.

NAS/NRC (National Academy of Sciences/National Research Council), 2003. A Review of the Dose Reconstruction Program of the Defense Threat Reduction Agency. National Research Council, Washington, D.C.

NBS (National Bureau of Standards), 1959. Maximum Permissible Body burdens and Maximum permissible concentration of Radionuclides in Air and Water for Occupational Exposure. National Bureau of Standards No. 69, Department of Commerce, National Bureau of Standards, Washington, DC. June 5.

NCRP (National Council on Radiation Protection and Measurements), 1993. Uncertainty in NCRP Screening Models Relating to Atmospheric Transport, Deposition and Uptake by Humans, NCRP Commentary No. 8. National Council on Radiation Protection and Measurements (NCRP), Bethesda, MD. September 1.

NCRP (National Council on Radiation Protection and Measurements), 2009. Ionizing Radiation Exposure of the Population of the United States, NCRP Report No.160. National Council on Radiation Protection and Measurements (NCRP), Bethesda, MD.

NDC (Naval Dosimetry Center), 1962-1979. Exposure to Ionization Radiation reports, 19621979. U.S. Naval Dosimetry Center, Bethesda, MD.

NNPU (Naval Nuclear Power Unit), 1967. Chemistry Manual, Chapter 9, Monitoring of Gaseous Radioactive Release. U.S. Naval Nuclear Power Unit, Fort Belvoir, VA. November 15.

NNPU (Naval Nuclear Power Unit), 1969, Operation Log for Health Physics, Nov 1967 to Jan 1969, McMurdo Station. U.S. Naval Nuclear Power Unit, Fort Belvoir, VA. 
NNPU (Naval Nuclear Power Unit), 1973a. Final Operating Report for PM-3A Nuclear Power Plant McMurdo Station, Antarctica. U.S. Naval Nuclear Power Unit, Fort Belvoir, VA. October.

NNPU (Naval Nuclear Power Unit), 1973b. Removal Plan for the PM-3A Nuclear Power Plant McMurdo Station, Antarctica. U.S. Naval Nuclear Power Unit, Fort Belvoir, VA. September.

NNPU (Naval Nuclear Power Unit), 1976. Operation Log for Health Physics, June 1974 to Feb 1976, McMurdo Station. U.S. Naval Nuclear Power Unit, Fort Belvoir, VA.

NNPU (Naval Nuclear Power Unit), 1977a. Radiation Work Permit No 05-76. U.S. Naval Nuclear Power Unit, Fort Belvoir, VA. February 2.

NNPU (Naval Nuclear Power Unit), 1977b. Operation Log for Health Physics, October 1976 to Feb 1977, McMurdo Station. U.S. Naval Nuclear Power Unit, Fort Belvoir, VA.

NNPUD (Naval Nuclear Power Unit Detachment), 1972. Shipment of Radioactive Material, NNPUDETMCMINST 11310.7B. Naval Nuclear Power Unit Detachment, FPO San Francisco, CA. July 27.

U.S. Navy, 1972a. Radioactive Waste Disposal Record. NavDocks Form 3012, April 6, 1972.

U.S. Navy, 1972b. Whole Body Counting Report, Whole Body Counting Facility, Department of Radiology, National Naval Medical Center, Bethesda, MD. Nov 29.

USD(P\&R) (Under Secretary of Defense for Personnel \& Readiness), 2011. Letter to Senator Brown, OH, regarding McMurdo Station Radiation Personnel Exposures. Washington, DC. May 2.

USEPA (United States Environmental Protection Agency), 2011. Exposure Factors Handbook:2011. EPA/600/R-090-052F, Office of Research and Development, National Center for Environmental Assessment, Washington, DC. September.

USNRC (United States Nuclear Regulatory Commission), 2011a. Transportation of Radioactive Material, U.S. Nuclear Regulatory Commission Training Center, Chattanooga, TN.

USNRC (United States Nuclear Regulatory Commission), 2011b. Washington State University; Facility Operating License No. R-76; Washington State University Modified TRIGA Nuclear Radiation Center Reactor (NRCR); Environmental Assessment and Finding of No Significant Impact. Federal Register, Vol. 75, No. 179, U.S. Nuclear Regulatory Commission, Rockville, MD. September 16.

USNRC (United States Nuclear Regulatory Commission), 2012a. University of Wisconsin; University of Wisconsin Nuclear Reactor Environmental Assessment and Finding of No Significant Impact. Federal Register. Vol. 76. No. 74, U.S. Nuclear Regulatory Commission, Rockville, MD. April 19.

USNRC (United States Nuclear Regulatory Commission), 2012b. Title 10, Code of Federal Regulations, Standards for Protection Against Radiation, Appendix B, Annual Limits on Intake (ALIs) and Derived Air Concentrations (DACs) of Radionuclides for Occupational Exposure; Effluent Concentrations; Concentrations for Release to Sewerage. U.S. Nuclear Regulatory Commission, Rockville, MD., January 31. 
USPHS (United States Public Health Service), 1963. A Manual for Environmental Radiation Surveillance at McMurdo Station, Antarctica. Division of Radiological Health, U.S. Public Health Service, U.S Department of Health, Education, and Welfare, Washington, DC. July.

VBA (Veterans Benefits Administration), 2006. "Centralization of Radiation Claims Processing". VBA Fast Letter 06-20, Washington, DC. October 16

VBDR (Veterans’ Advisory Board on Dose Reconstruction), 2012. Executive Summary Minutes from Annual Meeting, San Antonio, Texas, March 23-24.

Zhu, Y., Hinds W.C., Krudysz, M., Kuhn, T., Froines, J., and Sioutas, C., 2005. "Penetration of Freeway Ultrafine Particles into Indoor Environments”. Journal of Aerosol Science, Volume 36, pp. 303-322. 
Appendix A.

Congressional Inquiries Regarding Veterans' Exposures to Radiation from the McMurdo Station Nuclear Power Plant 


\section{A-1. Letter from Senator Brown to Secretary of Defense}

\author{
SHERROD BROWH
OHIO \\ AGRICULTURE, NUTRTION \\ AND FORESTRY \\ APPROPRIATIONS \\ BANKING, HOUSING. \\ VETERANS' AFFAIRS \\ SELECT COMMITTEE ON ETHICS
}

\section{LAnited States Senate \\ WASHINGTON, DC 20510}

March 10, 2011

The Honorable Robert M. Gates

Secretary of Defense

1000 Defense Pentagon

Washington, DC 20301-1000

Dear Secretary Gates:

I am writing to express my concern regarding a potential exposure issue that is substantiated by an official document released by the Department of the Navy. I hope that you will give this matter your full consideration.

The Final Operating Report for PM-3A Nuclear Power Plant McMurdo Station, Antarctica as prepared by the U.S. Naval Nuclear Power Unit, indicates that the PM-3A was shut down nearly $30 \%$ of its available operating time. This was due to the plant's 438 reported malfunctions over the period of March 12, 1964 through September 30, 1973.

According to this document, there were 123 reports of personnel exposure in excess of allowable limits over the course of seven consecutive days, four reports of radioactivity being released into the environment in excess of allowable limits, and 41 cases of radiation levels being reported in excess of three times the normal level. In addition, there are docurnented cases of airborne radioactivity exposure to personnel.

Veterans who were stationed at McMurdo have developed cancers, including U.S. Navy veteran Mr. Charles Swinney from Pataskala, Ohio. Mr. Swinney died with more than 200 tumors in his body. His claim for service-connected disability due to radiation exposure was denied by the

Veterans Benefits Administration (VBA) within the Department of Veterans Affairs. According to his dose-reconstruction, the probability of having his cancer being service-connected was nearly zero percent.

As you know, the VBA relies on documentation submitted by the appropriate Service Branch to determine the dose assessment of an exposure claim. The Interactive Radio Epidemiological Program (IREP) - constructed by the National Institute of Health - may not be suited to determine the likelihood of repeated exposure to low doses of radiation causing cancer many years after exposure. Given that this is the formula used to determine the outcome of McMurdo exposure claims, the Department of Defense may need to work with the Veterans' Advisory Board on Dose Reconstruction to reassess the IREP's ability to accurately determine the likelihood of causation for these types of claims. 
According to the United States Nuclear Regulatory Cormmission (USNRC), cancers that may develop as a result of radiation exposure are indistinguishable from those that $\propto c c u r$ naturally or as a result of exposure to other carcinogens. The USNRC further states that there are no data to establish unequivocally the occurrence of cancer following exposure to low doses and dose rates, but that the radiation protection community conservatively assumes that any amount of radiation may pose some risk for causing cancer. Furthermore, low doses spread out over long periods of time don't cause an immediate problem to any body organ. The effects of low doses of radiation, if any, would occur at the cell level, and thus changes may not be observed for many years (usually 5-20 years) after exposure.

Given the reported difficulty in differentiating between cancers that may develop as a result of radiation exposure and those that occur naturally or as a result of exposure to other carcinogens, we owe it to our veterans to err on the side of caution and support the claims of those who's cancer we cannot legitimately determine was not caused by radiation exposure at McMurdo Station.

I ask that you work with the Department of Veterans Affairs, the Veterans' Advisory Board on Dose Reconstruction, and any other relevant parties to review the existing methods used to evaluate the probability of radiation exposure at McMurdo Station causing cancer in veterans. These servicemembers deserve our full commitment to providing them with the disability benefits they are due.

I appreciate your attention to this matter and look forward to hear from you.

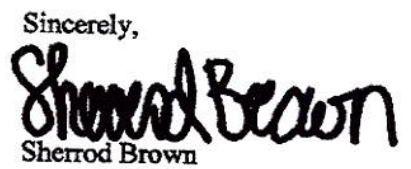

United States Senator

\section{A-2. DoD Response to Senator Brown.}




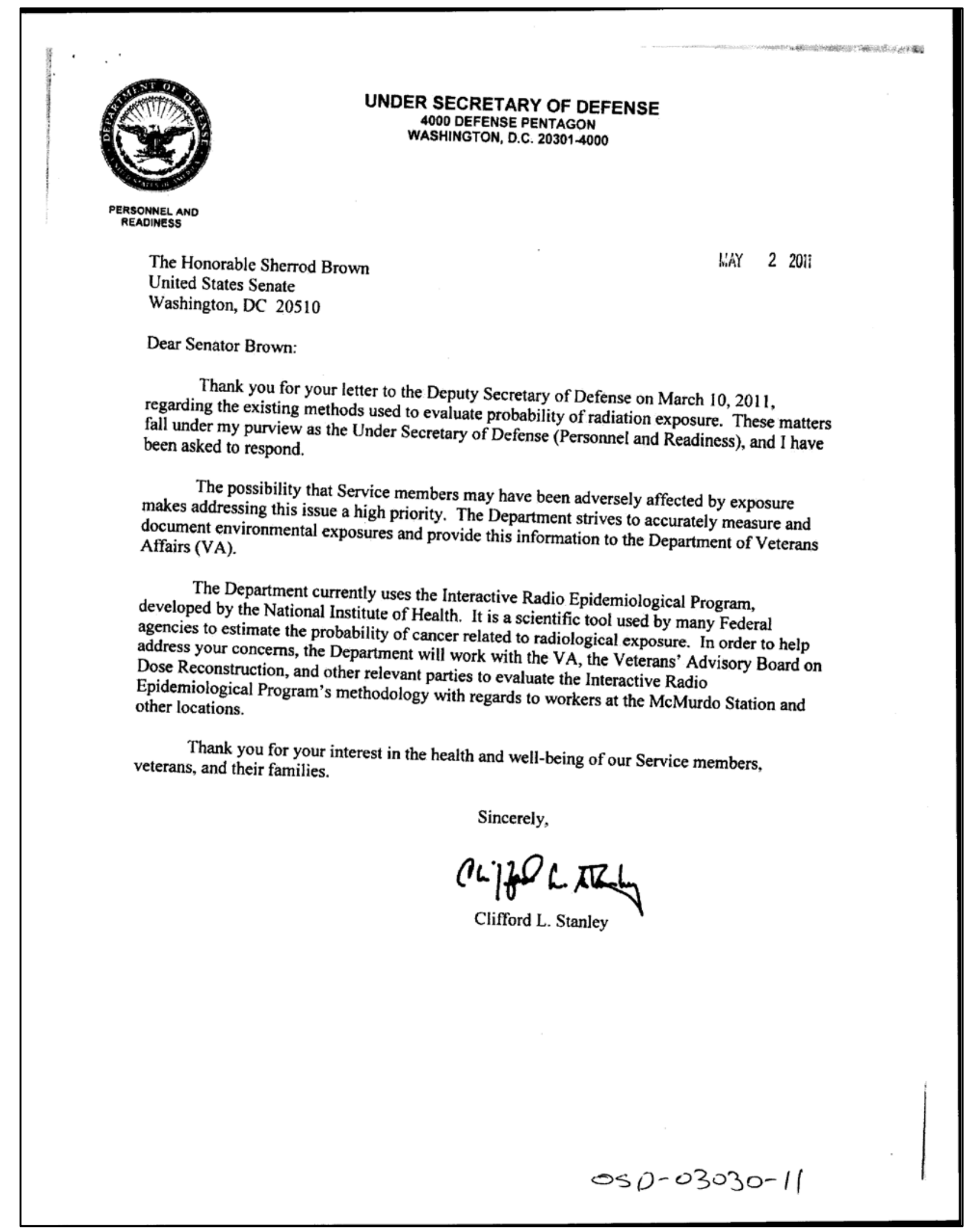

\section{A-3. Letter from Senator Blumenthal to Assistant Secretary of the Navy (Installations and Environment)}




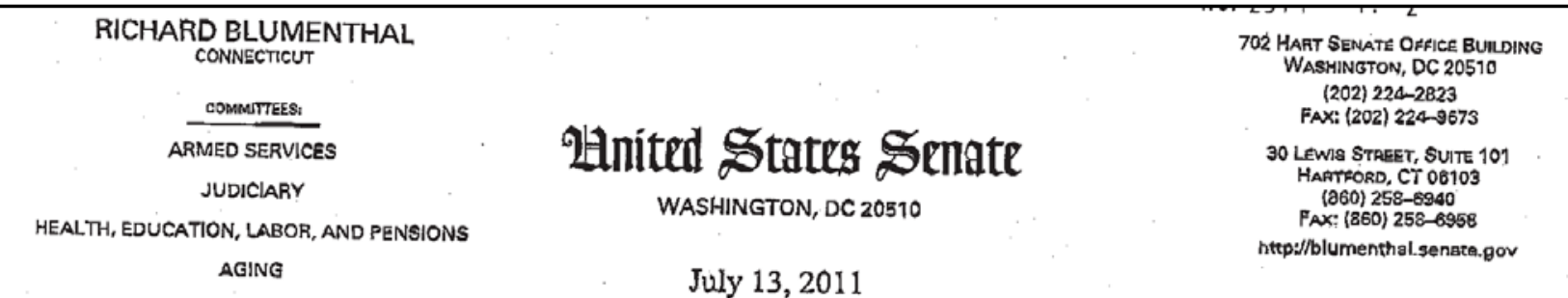

The Honorable Roger Natsuhara

Assistant Secretary of the Navy (Installations and Environment)

Department of the Navy

1000 Navy Pentagon, Room 4E731

Washington, DC 20350-1000

Dear Assistant Secretary Natsubara:

I respectfully request that you examine the likelihood that military personnel who served at the McMurdo Station, Antarctica between March 3, 1962, and October 20, 1973, may have been repeatedly exposed to radiation when the PM-3A Nuclear Power Plant provided the station with power.

The Navy concluded that there was no significant increase in radiation at the McMurdo Station area due to the operation of the PM-3A Nuclear Power Plant. However, prior to its decommissioning in 1973 due to stress corrosion problems, the Navy identified 438 malfunctions occurring at McMurdo Station and 123 documented instances of personnel exposure in excess of allowable limits over the course of seven consecutive days. The Navy identified four instances of radioactivity being released into the environment in excess of allowable limits, and 41 cases of radiation levels being reported in excess of three times the normal level. In addition, there were documented cases of airbome radioactivity exposure to personnel.

As you know, the Veterans Benefit Administration relies on documentation submitted by the appropriate Service Branch to determine the dose assessment of an exposure claim. Given these reported incidents, I ask that you work with the Assistant Secretary of the Navy for Manpower and Reserve Affairs, Veterans Benefit Administration, Veterans' Advisory Board on Dose Reconstruction, and any other relevant parties to thoroughly review the probability of radiation exposure at McMurdo Station. Resolving this issue will provide much needed answers for those who served at McMurdo Station as to whether they have any increased likelihood of a service-connected disability from radiation, such as cancer.

Thank you for your attention to this matter and I look forward to hearing from you.

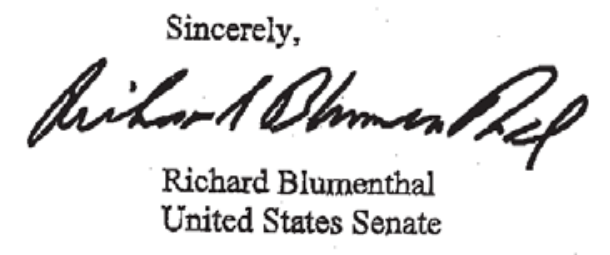

\section{A-4. Department of the Navy Response to Senator Blumenthal}




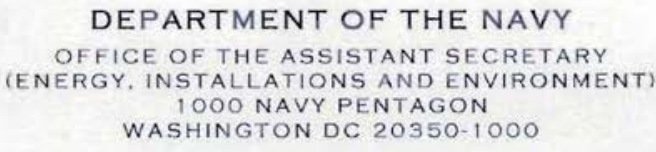

The Honorable Richard Blumenthal

United States Senate

Washington, DC 20510

Dear Senator Blumenthal:

This is to acknowledge your recent letter to me dated July 13, 2011 concerning the likelihood that military personnel may have been exposed to radiation from the PM-3A Nuclear Power Plant at McMurdo Station, Antarctica.

We are currently gathering information necessary to provide a substantive response to address your inquiry. Your letter addressed two principle desired actions regarding the PM-3A Nuclear Power Plant. First, examination of the likelihood of exposure to military personnel, and second, collaboration with Assistant Secretary of the Navy for Manpower and Reserve Affairs, Veterans Benefits Administration, Veterans' Advisory Board on Dose Reconstruction and all other relevant organizations to review the probability of exposure at McMurdo Station. These actions are similar to those currently being undertaken by the Defense Threat Reduction Agency (DTRA). We will ensure our efforts are coordinated with their research. While DTRA's research will not be completed until April 2012, I will keep you informed as our collective efforts progress.

In the interim, if you require further assistance, do not hesitate to contact me personally. Thank you for your advocacy for protecting the safety and health of our veterans and all our men and woman in uniform.

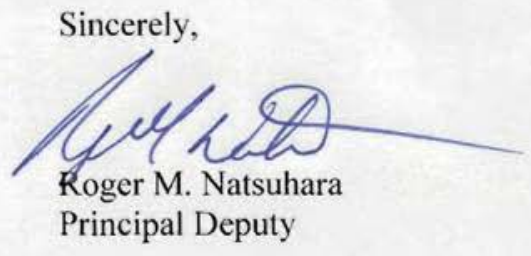


Appendix B.

Radiation Dose Calculation Methods and Parameter Definitions 


\section{B-1. External Dose Assessment Methods and Parameter Definitions}

\section{B-1.1. Average Hourly Dose Rate inside the NPP}

The average hourly dose rate inside the NPP is estimated using Equation 1 (DTRA, 2010, SM ED01):

$$
\dot{D}_{\text {average }}=\frac{F B_{\text {average }}}{T_{\text {Badge }}}
$$

where:

$\dot{D}_{\text {average }} \quad=\quad$ Average hourly dose rate inside the NPP $\left(\mathrm{mSv} \mathrm{h}^{-1}\right)$

$F B_{\text {average }} \quad=\quad$ Average annual film badge dose for each DF winter-over year (mSv)

$T_{\text {Badge }} \quad=\quad$ Time duration that the reactor crew members were monitored using film badges while inside the NPP (h)

For the years when no film badge data exist but environmental monitoring data exist, the average hourly dose rate inside the NPP is estimated using Equation 2 (DTRA, 2010, ED01):

$$
\dot{D}_{\text {average }}=\frac{T L D_{\text {highest }}}{T_{\text {monitor }} H_{D}}
$$

where:

$T L D_{\text {highest }} \quad=\quad$ Highest TLD measurement during environmental monitoring (mSv)

$T_{\text {monitor }} \quad=\quad$ Time duration that the TLD was used as an environmental monitor (h)

\section{B-1.2. External Dose from Touring or Visiting the NPP}

For a specific Deep Freeze year, the dose while touring or visiting the NPP is estimated using Equation 3 (DTRA, 2010, SM ED02):

$$
D_{\text {tour }}=\dot{D}_{\text {average }} T_{\text {tour }} N_{\text {tour }}
$$

where:

$D_{\text {tour }} \quad=\quad$ Dose due to touring or visiting the NPP $(\mathrm{mSv})$

$T_{\text {tour }} \quad=\quad$ Time duration that support personnel were inside the NPP for each tour or visit (h)

$N_{\text {tour }} \quad=\quad$ Number of visits to (or tours of) the NPP 


\section{B-1.3. External Dose from Transiting in Proximity to the NPP}

For a specific DF year, the dose while transiting in proximity to the NPP is estimated using Equation 4 (Cember, 1983) based upon the reduction in dose rate with the square of the distance given the assumed distances to the film badge and the NPP boundary:

$$
D_{\text {transit }}=\dot{D}_{\text {average }} T_{\text {boundary }} N_{\text {boundary }} \frac{d_{\text {badge }}{ }^{2}}{d_{\text {boundary }}{ }^{2}}
$$

where:

$D_{\text {transit }} \quad=\quad$ Dose due to transiting in proximity to the NPP (mSv)

$T_{\text {boundary }}=$ Time that a veteran would have been at the boundary during any transit near the NPP (h)

$N_{\text {boundary }}=\quad$ Number of transits near the NPP boundary

$d_{\text {badge }} \quad=\quad$ Distance from the NPP radiation sources to the assumed location of the average film badge $(\mathrm{m})$

$d_{\text {boundary }} \quad=\quad$ Distance from the NPP radiation sources to the NPP boundary $(\mathrm{m})$

\section{B-1.4. External Dose from Immersion in a Cloud of Noble Gases}

The dose due to immersion in a cloud of noble gases emitted from the NPP is estimated using Equation 5 (USNRC, 2012b):

$$
D_{n g}=D_{E C L} F_{\text {Wind }} \frac{C_{A r 41} T_{A r 41}}{E C L_{A r 41} T_{E C L}}
$$

where:

$D_{n g} \quad=\quad$ Dose due to immersion in a cloud of noble gases $(\mathrm{mSv})$

$D_{E C L} \quad=\quad$ Dose to a member of the general public from one year exposure to a cloud containing the effluent concentration limit for Ar-41

$F_{\text {Wind }} \quad=\quad$ Wind direction factor (the fraction of the time that the wind was blowing toward the area of interest)

$C_{\text {Ar41 }}=$ Maximum permissible concentration for Ar-41 that could be released from the NPP stack $\left(\mathrm{Bq} \mathrm{mL}{ }^{-1}\right)$

$E C L_{\text {Ar41 }}=$ Effluent concentration for Ar-41 that results in a permissible dose limit of 50 mrem in a year to a member of the general public $\left(\mathrm{Bq} \mathrm{mL}{ }^{-1}\right)$

$T_{\text {Ar41 }}=\quad$ Time duration that a veteran was immersed in a cloud of noble gases $(\mathrm{y})$

$T_{E C L} \quad=\quad$ Duration of exposure to effluent concentration for Ar-41 that results in a permissible dose limit of $50 \mathrm{mrem}$ in a year to a member of the general public (y) 


\section{B-1.5. External Dose from Movement of Radioactive Waste Packages outside the NPP}

The dose due to movement of radioactive waste packages outside the NPP is estimated using Equation 6 (Cember, 1983; USNRC, 2011a):

$$
D_{\text {Pack }}=\left(I_{I I} N_{I I}+I_{I I I} N_{I I I}\right) T_{\text {Package }} \frac{d_{\text {Index }}{ }^{2}}{d_{\text {Dose }}^{2}}
$$

where:

$\begin{array}{ll}D_{\text {pack }} & =\begin{array}{l}\text { Dose due to exposure during the movement of radioactive waste packages } \\ \text { outside the NPP (rem) }\end{array} \\ I_{I I} & =\begin{array}{l}\text { Exposure rate from a Yellow-II radioactive package at the distance that } \\ \text { the transportation index is determined }\left(\mathrm{mSv} \mathrm{h}^{-1}\right)\end{array} \\ I_{I I I} & =\quad \begin{array}{l}\text { Exposure rate from a Yellow-III radioactive package at the distance that } \\ \text { the transportation index is determined }\left(\mathrm{mSv} \mathrm{h}^{-1}\right)\end{array} \\ N_{I I} & =\quad \begin{array}{l}\text { Number of Yellow-II packages to which a veteran would have been } \\ \text { exposed }\end{array} \\ N_{I I I} & =\quad \begin{array}{l}\text { exposed } \\ \text { Time duration that a veteran was near any one radioactive waste } \\ \text { package (h) }\end{array} \\ T_{\text {Package }} & =\quad \begin{array}{l}\text { Distance at which the transportation index was determined (m) } \\ \text { Assumed distance from the surface of the radioactive waste packages to } \\ \text { the veteran (m) }\end{array}\end{array}$

\section{B-1.6. External Dose from Shipments of Radioisotope Thermal Generators}

The dose due to shipment of RTGs is estimated using Equation 7 (Cember, 1983; USNRC, 2011a):

$$
D_{R T G}=I_{R T G} N_{R T G} T_{R T G} \frac{d_{\text {Index }}{ }^{2}}{d_{\text {Dose }}^{2}}
$$

\begin{tabular}{|c|c|c|}
\hline$D_{R T G}$ & $=$ & Dose due to shipments of RTGs (mSv) \\
\hline$I_{R T G}$ & $=$ & $\begin{array}{l}\text { Exposure rate from a Yellow-III radioactive package containing an RTG } \\
\text { at the distance that the transportation index is determined }\left(\mathrm{mSv} \mathrm{h}^{-1}\right)\end{array}$ \\
\hline$N_{R T G}$ & $=$ & Number of RTG packages to which a veteran could have been exposed \\
\hline$T_{R T G}$ & $=$ & Time duration that a veteran was near an RTG (h) \\
\hline
\end{tabular}

where: 


\section{B-1.7. External Dose from Contaminated Soil on the Ground}

The dose due to spilled contaminated soil on the ground before cleanup and residual contaminated soil on the ground after cleanup is estimated using Equation 8 (DTRA, 2010, SM ED02):

$$
D_{\text {soilext }}=\rho F_{\text {dose }}\left(C_{\text {High }} T_{\text {High }}+C_{\text {Low }} T_{\text {Low }}\right)
$$

where:

\begin{tabular}{|c|c|c|}
\hline$D_{\text {soilext }}$ & $=$ & Dose from exposure to contaminated soil on the ground (i.e., Shine) (mSv) \\
\hline$\rho$ & $=$ & Density of the soil $\left(\mathrm{g} \mathrm{m}^{-3}\right)$ \\
\hline$F_{\text {dose }}$ & $=$ & $\begin{array}{l}\text { Dose coefficient assuming an infinite plane of Cs-137 contamination at a } \\
\text { depth of } 1 \mathrm{~cm}\left(\mathrm{mSv} \mathrm{m} \mathrm{h}^{-1} \mathrm{~Bq}^{-1}\right)\end{array}$ \\
\hline$C_{\text {High }}$ & $=$ & Maximum activity concentration for contaminated soil on ground $\left(\mathrm{Bq} \mathrm{g}^{-1}\right)$ \\
\hline$C_{\text {Low }}$ & $=$ & $\begin{array}{l}\text { Maximum permissible activity concentration of residual contaminated soil } \\
\text { on ground }\left(\mathrm{Bq} \mathrm{g}^{-1}\right)\end{array}$ \\
\hline$T_{\text {High }}$ & $=$ & $\begin{array}{l}\text { Time duration that a veteran was exposed to spilled contaminated soil on } \\
\text { the ground before cleanup (h) }\end{array}$ \\
\hline$T_{\text {Low }}$ & $=$ & $\begin{array}{l}\text { Time duration that a veteran was exposed to residual spilled contaminated } \\
\text { soil on the ground after cleanup (h) }\end{array}$ \\
\hline
\end{tabular}

\section{B-2. Inhalation Dose Assessment Methods and Parameter Definitions}

\section{B-2.1. Inhalation of Airborne Radioactive Materials}

The dose due to inhalation of airborne radioactive materials is estimated using Equations 9a, b and c (DTRA, 2010, SM ID01):

$$
\begin{gathered}
D_{\text {betainh }}=D_{F O}+D_{\text {NPPeff }} \\
D_{F O}=B R C_{\text {Cesium }} D C_{\text {Cesium }}\left(F_{\text {out }}+F_{\text {inside }} F_{\text {inf }}\right) T_{A A} \\
D_{\text {NPPeff }}=B R C_{\text {Iodine }}\left[D C_{\text {Igas }} F_{\text {Iodine }}+D C_{\text {Iaero }}\left(F_{\text {out }}+F_{\text {inside }} F_{\text {inf }}\right)\right] T_{\text {AA }}
\end{gathered}
$$

where:

$\begin{array}{lll}D_{\text {betainh }} & = & \begin{array}{l}\text { Dose from inhalation of gross long-lived, beta-emitting airborne } \\ \text { radioactive materials }(\mathrm{mSv})\end{array} \\ D_{F O} & = & \begin{array}{l}\text { Dose from inhalation of gross long-lived, beta-emitters in worldwide } \\ \text { fallout }(\mathrm{mSv})\end{array} \\ D_{N P P e f f} & = & \begin{array}{l}\text { Dose from inhalation of gross long-lived, beta-emitting radioactive } \\ \text { material in the air effluents released from the NPP (mSv) }\end{array} \\ B R & = & \begin{array}{l}\text { Breathing rate }\left(\mathrm{m}^{3} \mathrm{~h}^{-1}\right) \\ T_{A A}\end{array} \\ \text { Time duration for inhalation of airborne radioactive materials (h) }\end{array}$




$\begin{array}{lll}C_{\text {Iodine }} & = & \begin{array}{l}\text { Average concentration of long-lived, gross beta-emitting radioactive } \\ \text { aerosols for duration of intake, assumed to all be from aerosol I-131 } \\ \left(\mathrm{Bq} \mathrm{m}^{-3}\right)\end{array} \\ C_{\text {Cesium }} & =\quad \begin{array}{l}\text { Average concentration of long-lived, gross beta-emitting radioactive } \\ \text { aerosols assumed to all be from aerosol Cs-137 }\left(\mathrm{Bq} \mathrm{m}^{-3}\right)\end{array} \\ D C_{\text {Igas }} & =\quad \begin{array}{l}\text { Inhalation dose coefficient of elemental gaseous I-131 (effective dose or } \\ \text { organ dose) }\left(\mathrm{mSv} \mathrm{Bq}^{-1}\right)\end{array} \\ D C_{\text {Iaero }} & =\quad \begin{array}{l}\text { Inhalation dose coefficient of aerosol I-131 (effective dose or equivalent } \\ \text { dose for an organ) }\left(\mathrm{mSv} \mathrm{Bq}^{-1}\right)\end{array} \\ D C_{\text {Cesium }} & =\quad \begin{array}{l}\text { Inhalation dose coefficient of aerosol I-131 (effective dose or equivalent } \\ \text { dose for an organ) }\left(\mathrm{mSv} \mathrm{Bq}^{-1}\right)\end{array} \\ F_{\text {Iodine }} & =\quad \begin{array}{l}\text { Ratio of gaseous I to aerosol I } \\ F_{\text {out }}\end{array} & =\quad \begin{array}{l}\text { Fraction of the day that a veteran was outside } \\ F_{\text {inside }}\end{array} \\ F_{\text {inf }} & =\quad \begin{array}{l}\text { Fraction of the day that a veteran was inside } \\ \text { Infiltration factor for aerosols for indoor locations }\end{array}\end{array}$

\section{B-2.2. Inhalation of Suspended Contaminated Soil during Decommissioning}

The dose due to inhalation of suspended contaminated soil during decommissioning is estimated using Equation 10 (DTRA, 2010, SM ID01):

$$
D_{\text {soilinh }}=B R \quad C_{\text {Csaero }} D C_{\text {Csaero }} T_{\text {soil }}
$$

where:

$\begin{array}{lll}D_{\text {soilinh }} & = & \begin{array}{l}\text { Inhalation dose from suspended contaminated soil during } \\ \text { decommissioning }(\mathrm{mSv})\end{array} \\ C_{\text {Csaero }} & = & \begin{array}{l}\text { Highest measured concentration of Cs-137 in air samples taken during soil } \\ \text { decontamination }\left(\mathrm{Bq} \mathrm{m}{ }^{-3}\right)\end{array} \\ D C_{\text {Csaero }} & = & \text { Inhalation dose coefficient of aerosol Cs-137 }\left(\mathrm{mSv} \mathrm{Bq}^{-1}\right) \\ T_{\text {soil }} & = & \text { Time duration for soil intake at the specified concentration (h) }\end{array}$

\section{B-2.3. Inhalation of Contaminated Soil on the Ground, Roads, and Ship Loading Areas}

The dose due to inhalation of spilled contaminated soil before clean-up and residual contaminated soil after spill clean-up on the ground, roads, and ship loading areas is estimated using Equation 11 (DTRA, 2010, SM ID01):

$$
D_{\text {Ispillsoil }}=B R K D C_{\text {Csaero }} \rho \operatorname{Thick}\left(C_{\text {Cshigh }} T_{\text {High }}+C_{\text {Cslow }} T_{\text {Low }}\right)
$$

where:

$\begin{array}{lll}D_{\text {Ispillsoil }} & = & \begin{array}{l}\text { Inhalation dose from exposure to contaminated soil on the ground, roads, } \\ \text { and ship loading area }(\mathrm{mSv})\end{array} \\ K & = & \text { Suspension factor for soil contamination on the ground }\left(\mathrm{m}^{-1}\right) \\ C_{\text {Cshigh }} & = & \begin{array}{l}\text { Maximum measured concentration of Cs-137 in contaminated soil } \\ (\mathrm{Bq} \mathrm{g})\end{array}\end{array}$


$C_{\text {Cslow }} \quad=\quad$ Maximum permissible concentration of Cs-137 in residual soil contamination $\left(\mathrm{Bq} \mathrm{g}^{-1}\right)$

Thick $\quad=\quad$ Assumed thickness of the spilled or residual contaminated soil (m)

\section{B-3. Ingestion Dose Assessment Methods and Parameter Definitions}

\section{B-3.1. Ingestion of Tritium in Drinking Water}

The dose due to ingestion of tritium in drinking water is estimated using Equation 12 (DTRA, 2010, SM ID01):

$$
D_{\text {H3ing }}=D R_{\text {water }} C_{H 3 \text { water }} D C_{H 3 \text { ing }} T_{\text {Water }}
$$

where:

$D_{\text {H3ing }} \quad=\quad$ Ingestion dose from tritium in the drinking water for each year $(\mathrm{mSv})$

$D R_{\text {water }} \quad=\quad$ Ingestion volume of drinking water $\left(\mathrm{L} \mathrm{d}^{-1}\right)$

$C_{\text {H3water }}=$ Average concentration of tritium in drinking water for duration of intake $\left(\mathrm{Bq} \mathrm{L}^{-1}\right)$

$D C_{H 3 i n g} \quad=\quad$ Dose coefficient for ingestion of tritium $\left(\mathrm{mSv} \mathrm{Bq}^{-1}\right)$

$T_{\text {Water }} \quad=\quad$ Time duration for water intake at the specified concentration $(\mathrm{d})$

\section{B-3.2. Ingestion of Other Long-Lived Beta Emitters in Drinking Water}

The dose due to ingestion of long-lived beta emitters in drinking water is estimated using Equation 13 (DTRA, 2010, SM ID01):

$$
D_{\text {betaing }}=D R_{\text {water }} C_{\beta \text { water }} D C_{\text {Csing }} T_{\text {Water }}
$$

where:

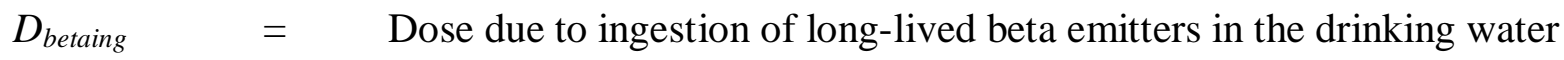
(mSv)

$C_{\beta \text { water }}=\quad$ Average concentration of Cs-137 in drinking water for duration of intake $\left(\mathrm{Bq} \mathrm{L}^{-1}\right)$

$D C_{C s i n g} \quad=\quad$ Dose coefficient for ingestion of Cs-137 $\left(\mathrm{mSv} \mathrm{Bq}^{-1}\right)$

\section{B-3.3. Incidental Ingestion of Contaminated Soil and Dust}

The dose due to incidental ingestion of spilled contaminated soil and dust before clean-up and residual contaminated soil and dust after clean-up is estimated using Equation 14 (DTRA, 2010, SM ID01):

$$
D_{\text {soiling }}=D S_{\text {soil }} D C_{\text {CSing }}\left(T_{\text {High }} C_{\text {Cshigh }}+T_{\text {Low }} C_{\text {Cslow }}\right)
$$

where: 
$D_{\text {soiling }} \quad=\quad$ Dose from incidental ingestion of contaminated soil and dust (mSv)

$D S_{\text {soil }} \quad=\quad$ Mass of soil and dust incidentally ingested each day $\left(\mathrm{g} \mathrm{d}^{-1}\right)$

$T_{\text {High }}=$ Time duration for incidental ingestion of residual contaminated soil before clean up (d)

$T_{\text {Low }} \quad=\quad$ Time duration for incidental ingestion of residual contaminated soil after clean up (d)

\section{B-4. Dose Uncertainty Methods and Parameter Definitions}

\section{B-4.1. Uncertainty in External Doses}

The upper-bound total external dose for McMurdo Station support personnel is estimated using Equation 15, which assumes that the dose components are uncorrelated (DTRA, 2010, SM UA01):

$$
D_{\text {UBext }}=\sum_{j=1}^{N D E} D_{e x t, j}+\sqrt{\sum_{j=1}^{N D E}\left[D_{e x t, j}\left(U F_{e x t}-1\right)\right]^{2}}
$$

where:

$D_{\text {UBext }} \quad=\quad$ Upper-bound total external dose due to all sources of external radiation (mSv)

$D_{\text {ext }, j} \quad=\quad$ The external dose component from each source/pathway (mSv)

$j \quad=\quad j^{\text {th }}$ component of the total external dose

$U F_{\text {ext }} \quad=\quad$ Uncertainty factor for external doses

NDE $\quad=\quad$ Number of external dose components

\section{B-4.2. Uncertainty in Internal Doses}

The upper-bound total internal dose for the McMurdo Station support personnel is estimated using Equation 16, which assumes that the dose components are fully correlated (DTRA, 2010, SM UA01):

$$
U B_{i n t}=\left(\sum_{j=1}^{N D I} D_{i n t, j}\right) U F_{i n t}
$$

where:

$U B_{\text {int }} \quad=\quad$ Upper-bound internal dose due to all sources of internal radiation for each year $(\mathrm{mSv})$

$D_{\text {int }, j} \quad=\quad$ The internal dose component from each source/pathway (mSv)

$j \quad=\quad j^{\text {th }}$ component of the total internal dose

NDI $\quad=\quad$ Number of internal dose components

$U F_{\text {int }} \quad=\quad$ Uncertainty factor for internal doses 
Appendix C.

McMurdo Station Radiation Dose Assessment Questionnaire 


\section{U.S. Naval Dosimetry Center \\ McMurdo Station Radiation Dose Assessment Questionnaire}

\section{TO START, SELECT ONE OF THE FOLLOWING TWO CATEGORIES:}

$\square \quad$ You were a military person who was NOT ASSIGNED to the McMurdo Nuclear Power Plant (NPP) (Support person or support personnel, hereafter) $\quad \rightarrow \quad$ [Please complete Sections I, II, III and V]

$\square \quad$ You were a military person who was ASSIGNED to the McMurdo NPP

(Reactor crew member, hereafter)

$\rightarrow \quad$ [Please complete Sections I, II, IV and V]

\section{SECTION I: PARTICIPANT CONTACT INFORMATION}

\begin{tabular}{|l||l||l}
\hline Name: (Last, First, Middle Initial) & Service Number: & Social Security Number: \\
\hline
\end{tabular}

Mailing Address:

Telephone:

Cell Phone:

Email:

If this questionnaire is completed by someone other than the participant, please provide:

Name: (Last, First, Middle Initial)

Mailing Address:

Telephone:

Cell Phone:

Email:

Relationship to veteran:

SECTION II: ASSIGNMENT SUMMARY (At McMurdo Station)

\begin{tabular}{|c|c|l|l|l|}
\hline \multicolumn{2}{|c||}{ Dates Assigned } & \multirow{2}{*}{ Rate/Rank } & \multirow{2}{*}{ Name(s) of Person(s) who Severed with You } \\
\hline \hline Arrival Date & Departure Date & & \\
\hline & & & \\
\hline & & & & \\
\hline & & & & \\
\hline & & & & \\
\hline
\end{tabular}




\section{SECTION III: MCMURDO STATION SUPPORT PERSON}

The following questions are intended to assess your potential for radiation exposure for a support person who was NOT ASSIGNED to the McMurdo NPP. Please provide detailed answers to the best of your recollection. Qualify as "approximate” where necessary. If more space is needed for any question, use additional sheets and include reference to section and question numbers. If you are unable to answer a question, state "Unknown".

If you were assigned to McMurdo Station from 1962 to 1972, please complete the questions in A, C and D.

If you were assigned to McMurdo Station from 1973 to 1979, please complete the questions in B, C and D.

If you were assigned to McMurdo Station during both periods, please complete the questions in A, B, C and D.

\section{A. Assigned to McMurdo Station while the NPP was operational (1962-1972)}

1. Did you ever enter the NPP facility such as the reactor building, supply building, or the fenced yard? Yes No

If No, skip to the next numbered question. If Yes, answer the following sub-questions:

o Approximately, how many times did you enter the NPP facility?

$0 \quad$ What were the reasons for going into the NPP facility?

o What areas and buildings were you in and what activities did you carry out while at the NPP?

2. Did you handle radioactive waste or packages such as helping move radioactive waste or helping load packages containing radioactive material on a ship? Yes No

If No, skip to the next numbered question. If Yes, answer the following sub-questions:

o What was your role in the handling of waste or packages containing radioactive material?

o How many times approximately?

o For how long on average each time? 
3. Did you ever handle, transport, or work in close proximity to radioisotope thermal generators (RTGs)? Yes No

If No, skip to the next numbered question. If Yes, answer the following sub-questions:

o Describe your activities in handling, transporting, working near RTGs:

o Approximately how many times did you handle RTGs?

o How long did each time take on average?

4. In the course of your duties or during off time, did you transit near the NPP, such as walked/hiked or drove/rode near the fenced area of the facility? Yes No

If No, skip to the next numbered question. If Yes, answer the following sub-questions:

o Describe the purpose of your transit(s) near the fenced area of the NPP:

o How many times did you transit near the fenced area of the NPP?

o How long each transit lasted on average?

5. Are there any other duties, actions or locations that you think may have caused you to be exposed to radiation from the McMurdo NPP?

6. Where were your living quarters while at McMurdo Station?

7. Where did you have your meals while at McMurdo Station? 


\section{B. Assigned to McMurdo Station while the NPP was decommissioned (1973-1979)}

1. Did you ever enter the NPP facility during decommissioning? Yes No If No, skip to the next numbered question. If Yes, answer the following sub-questions:

o Approximately, how many times did you enter the facility?

0 What were the reasons for entering the NPP facility?

o What areas and buildings were you in and what activities did you carry out in the NPP?

2. Did your duties require you to assist in the decommissioning of the NPP? Yes No If No, skip to the next numbered question. If Yes, answer the following sub-questions:

o What did you do to assist in decommissioning activities?

o How many hours/days did you spend inside the NPP facility assisting in its decommissioning?

3. Did you handle radioactive waste such as helped move radioactive waste or load packages containing radioactive materials on a ship? Yes No

If No, skip to the next numbered question. If Yes, answer the following sub-questions:

o What was your role in the handling of waste or packages containing radioactive materials?

o How many times approximately?

o For how long on average each time? 
4. Did you ever handle or work in close proximity to radioisotope thermal generators (RTGs)? Yes No

If No, skip to the next numbered question. If Yes, answer the following sub-questions:

o Describe your activities in handling, transporting or working near RTGs:

o Approximately, how many times did you handle RTGs?

o How long did each time take on average?

5. In the course of your duties or during off time, did you transit near the NPP, such as walked/hiked or drove/rode near the fenced area of the facility? Yes No

If No, skip to the next numbered question. If Yes, answer the following sub-question:

o Describe the purpose of your transit(s) near the fenced area of the NPP:

o How many times total did you transit near the fenced area of the NPP?

o How long each transit lasted on average?

6. Are there any other duties, actions or locations that you think may have caused you to be exposed to radiation from the decommissioning of the McMurdo NPP?

7. Where were your living quarters while at McMurdo Station?

8. Where did you have your meals while at McMurdo Station? 


\section{Radiological Monitoring}

1. Were you issued a film badge (radiation dosimeter) during your assignment at McMurdo Station? Yes No

If No, skip to Section D If Yes, answer the following sub-question:

o Provide details (i.e., when did you wear the dosimeter, in what areas, etc.):

2. Were you ever advised of the results of the badge readings? Yes No If No, skip to D. If Yes, answer the following sub-question:

o Please give any details you remember about your film badge doses:

\section{Additional Comments}

1. Add any information you believe was not covered under the questions in this section:

\section{SECTION IV: McMurdo Station REACTOR CREW MEMBERS}

The following questions are intended to assess your potential for radiation exposure as an individual who was ASSIGNED to the NPP as a reactor crew member. Please provide detailed answers to the best of your recollection. Qualify as "approximate” where necessary. If more space is needed for any question, use additional sheets and include reference to section and question numbers. If you are unable to answer a question, state "Unknown".

If you were assigned to McMurdo Station from 1962 to 1972, please complete the questions in A, C and D.

If you were assigned to McMurdo Station from 1973 to 1979, please complete the questions in B, C and D.

If you were assigned to McMurdo Station both periods, please complete the questions in A, B, C and D. 


\section{A. Assigned to the NPP while in operation (1962-1972)}

1. What was your job/duty at the NPP?

2. Provide details of your work and radiation exposure at the NPP (i.e., which building/area you worked in, duties requiring radiation work permits, incident, use of personal protective equipment, etc.):

3. Were you issued film badge dosimeters (radiation dosimeters) during your assignment? Yes No

If Yes, skip to next sub-question. If No, answer the following sub-question and skip to the next numbered question:

o Do you know the reasons why you were not issued film badges?

o Did you wear the badge during plant operations? Yes No

If Yes, skip to next numbered question. If No, answer the following:

At what times did you NOT wear your film badge and what was the reason for NOT wearing your film badge? 
4. Answer the following questions if you were monitored for internal deposition of radionuclides such as a whole-body count or bioassay sample after returning to the United States.

o Was a whole-body count or thyroid count performed on you? Yes _ _ No

If Yes, when and where did you receive a whole-body count?

o Was a radiation bioassay such as a urine bioassay for radioactive material ever performed?

Yes No

If Yes, when and where did you receive a bioassay test?

5. We you assigned to other nuclear power plants while in military service? Yes No If No, skip to the next numbered question. If Yes, answer the following sub-question:

o Where and when were you assigned to other nuclear power plants while in military service? _

6. Are there any other duties, actions or locations that you think may have caused you to be exposed to radiation from the operation of the McMurdo NPP that would not have been recorded by your film badges (if one was issued)?

7. Where were your living quarters while at McMurdo Station?

8. Where did you have your meals while at McMurdo Station?

\section{B. Duties at the NPP during decommissioning (1973-1979)}

1. What was your job/duty at the NPP during decommissioning? 
2. Provide details of your work and radiation exposure at the NPP (i.e., defueling, decontamination, dismantling, removal of contaminated soil, use of personal protective equipment, etc.):

3. Were you issued film badge dosimeters (radiation dosimeters) during your assignment? Yes _ No No

If Yes, skip to next sub-question. If No, answer the following sub-questions and skip to the next numbered question:

o Do you know the reasons why you were not issued film badges?

o If you were issued film badges, were there times when you did NOT wear them? Please state when you did NOT wear the film badges and the reasons for not wearing them:

4. Answer the following questions if you were monitored for internal deposition of radionuclides such as a whole-body count or bioassay sample after returning to the United States.

o Was a whole-body count or thyroid count performed on you? Yes No

If Yes, when and where did you receive a whole-body count?

o Was a radiation bioassay such as a urine bioassay for radioactive material ever performed? Yes No

If Yes, when and where did you receive a bioassay test? 
5. We you assigned to other nuclear power plants while in military service? Yes No If No, skip to the next numbered question. If Yes, answer the following sub-question:

o Where and when were you assigned to other nuclear power plants while in military service?

6. Are there any other duties, actions or locations that you think may have caused you to be exposed to radiation from the decommissioning of the McMurdo NPP that would not have been recorded by your film badge (if one was issued)?

7. Where were your living quarters while at McMurdo Station?

8. Where did you have your meals while at McMurdo Station?

\section{Historical documentation}

1. Do you have any historical records that might be relevant to radiation exposure such as Form DD 1141 or the results of internal monitoring? Yes No

If No, skip to the next numbered question. If Yes, answer the following sub-question:

o Please include a copy of such documents with this returned form and identify the documents here: 
2. Do you know the name of anyone who was at McMurdo Station during the same time period and performed the same or similar duties? Yes _ N No

If No, skip to the next numbered question. If Yes, answer the following sub-question:

o Provide the names of colleagues and coworkers who may have had similar radiation exposures:

\section{Additional Comments}

1. Add any information you believe was not covered under the questions in this section:

SECTION V: SIGNATURE

I certify under penalty of perjury under the laws of the United States of America that the information provided on this form is true and correct.

Print Name:

Signature:

Date: 


\section{SECTION VI: PRIVACY ACT STATEMENT}

AUTHORITY: 38 U.S.C. 1154 (Veterans’ Benefits) delineates United States Navy (USN) and Department of Veterans Affairs (VA) responsibilities for collection of information in the adjudication of non-presumptive radiogenic disease compensation.

PRINCIPAL PURPOSES: The information on this form is necessary to facilitate location of record(s) or information, provide participation and dose information, support scientific studies or medical follow-up programs, and provide data or documentation relevant to the processing of administrative claims or litigation. For use by Agency officials, employees, and authorized contractors.

ROUTINE USES: Disclosures are permitted under 5 U.S.C. 552a(b) of the Privacy Act, to USN, VA, Department of Defense, Veterans' Advisory Board on Dose Reconstruction and under the 'Blanket Routine Uses' published at the beginning of USN's compilation of systems of records notices.

DISCLOSURE: Voluntary. However, failure to provide the requested information may delay or preclude the USN/VA from producing your radiation dose assessment.

\section{SECTION VII: AGENCY DISCLOSURE NOTICE}

The public reporting burden for this collection of information is estimated to be less than one hour. If you have any questions regarding this form, please write to Officer in Charge, Naval Dosimetry Center, Bldg 4/6, 4th Floor, 8901

Wisconsin Ave, Bethesda, MD 20889-5614 


\section{Abbreviations, Acronyms, and Unit Symbols}

\begin{tabular}{ll} 
AEC & Atomic Energy Commission \\
Ar & argon \\
ASN(E,I\&E) & Assistant Secretary of the Navy for Energy, Installations, and \\
& Environment \\
ASTSWMO & Association of State and Territorial Solid Waste Management \\
& Officials \\
Bi & bismuth \\
Bq & becquerel \\
Ce & cerium \\
CDR & Commander \\
CFR & Code of Federal Regulations \\
Ci & curie \\
cm & centimeter \\
Co & cobalt \\
Cs & cesium \\
d & day \\
DD & Defense Department \\
DF & Deep Freeze \\
DoD & Department of Defense \\
DTRA & Defense Threat Reduction Agency \\
ED & external dose \\
EPA & Environmental Protection Agency \\
ERSP & Environmental Radiation Surveillance Program \\
g & gram \\
Gy & gray \\
HPS & Health Physics Society \\
HPSC & Health Physics Personal Safety and Chemistry \\
h & hour \\
I & iodine \\
IAEA & International Atomic Energy Agency \\
ID & internal dose \\
ICRP & International Commission on Radiological Protection \\
IMBA & Integrated Modules for Bioassay Analysis \\
IPT & Integrated Project Team \\
L & liter \\
LCDR & Lieutenant Commander \\
$\mathrm{m}$ & meter \\
$\mu$ HCi & microcurie \\
& \\
\hline &
\end{tabular}




\begin{tabular}{|c|c|}
\hline $\mathrm{mL}$ & milliliter \\
\hline$\mu \mathrm{m}$ & micrometer \\
\hline $\mathrm{Mn}$ & manganese \\
\hline MPBB & maximum permissible body burden \\
\hline MPC & maximum permissible concentration \\
\hline mrem & millirem \\
\hline $\mathrm{N}$ & number of years of age \\
\hline NAS & National Academy of Science \\
\hline NBS & National Bureau of Standards \\
\hline NCRP & National Council on Radiation Protection and Measurements \\
\hline NDC & Naval Dosimetry Center \\
\hline NIOSH & National Institute of Occupational Safety and Health \\
\hline NNPU & Naval Nuclear Power Unit \\
\hline NNPUD & Naval Nuclear Power Unit Detachment \\
\hline NPP & nuclear power plant \\
\hline NRC & National Research Council \\
\hline NTPR & Nuclear Test Personnel Review \\
\hline $\mathrm{pCi}$ & picocurie \\
\hline PM-1A & Portable, Medium type 1A Nuclear Power Plant \\
\hline PM-3A NPP & Portable, Medium type 3A Nuclear Power Plant \\
\hline $\mathrm{R}$ & roentgen \\
\hline RDA & radiation dose assessment \\
\hline rem & roentgen equivalent man \\
\hline RTG & radioisotope thermal generator \\
\hline $\mathrm{Ru}$ & ruthenium \\
\hline SC-1 & VBDR Subcommittee 1 on DTRA Dose Reconstruction Procedures \\
\hline SPARE & Scenario of Participation and Exposure \\
\hline $\mathrm{Sr}$ & strontium \\
\hline Sv & sievert \\
\hline $\mathrm{Tl}$ & thallium \\
\hline TLD & thermoluminescent dosimeter \\
\hline TRIGA & Training, Research, Isotopes, General Atomics \\
\hline UA & uncertainty analysis \\
\hline UB & upper-bound \\
\hline USDOE & United States Department of Energy \\
\hline USD(P\&R) & Under Secretary of Defense for Personnel and Readiness \\
\hline USEPA & United States Environmental Protection Agency \\
\hline USN & United States Navy \\
\hline USNRC & United States Nuclear Regulatory Commission \\
\hline USUHS & Uniformed Services University of the Health Sciences \\
\hline
\end{tabular}




$\begin{array}{ll}\text { VA } & \text { United States Department of Veterans Affairs } \\ \text { VARO } & \text { VA Regional Office } \\ \text { VBA } & \text { Veterans Benefits Administration } \\ \text { VBDR } & \text { Veterans' Advisory Board on Dose Reconstruction } \\ \text { VHA } & \text { Veterans Health Administration } \\ \text { wk } & \text { week } \\ \mathrm{Xe} & \text { xenon } \\ \mathrm{y} & \text { year } \\ \mathrm{Zr} & \text { zirconium }\end{array}$




\section{Authors' Biographies}

\section{Lieutenant Commander Gregory R. Fairchild, PhD}

Lieutenant Commander (LCDR) Fairchild is the Science and Research Advisor aboard the NDC. The NDC provides a centralized radiation dosimetry processing and consultation service to naval commands worldwide that use dosimetry as part of the Navy's Radiation Health Protection Program. It maintains a registry of ionizing radiation exposure data for Navy and Marine Corps personnel (military and civilian) exposed to radiation sources in their work environment, and responds to requests for exposure history information.

LCDR Fairchild is responsible for the accuracy and credibility of naval personnel radiation dose measurements, to include both external and internal assessments. He is directly responsible for accreditation of the Navy's current radiation dosimeter, the DT-702/PD, through the National Voluntary Laboratory Accreditation Program. Since 1990, he has worked in radiation physics in a variety of settings, including boiling water and pressurized water commercial nuclear power plants, environmental radiological cleanup, research facilities, universities, hospitals and aboard a U.S. Navy nuclear aircraft carrier.

LCDR Fairchild is a radiation health officer in the Navy Medical Services Corps. Prior to his current tour aboard the NDC, he served aboard Naval Medical Center San Diego, USS NIMITZ (CVN 68), Naval Hospital Okinawa Japan, and in duty under instruction at the University of Minnesota.

LCDR Fairchild is a plenary member of the Health Physics Society and a full member of the American Association of Physicists in Medicine. He completed a bachelor's degree in environmental and occupational health and safety at Brigham Young University, a master's degree in health physics at Texas A\&M University, and a doctorate degree in medical physics at University of Minnesota. He has coauthored articles on the influence of therapeutic radiation on bone.

He is a qualified Surface Warfare Medical Department Officer. His military decorations include two Navy Commendation Medals, the Navy Achievement Medal, a Navy Unit Commendation Medal, a Navy E Ribbon, the National Defense Service Medal, the Global War on Terrorism Expeditionary Medal, the Global War on Terrorism Service Medal, a Sea Service Deployment Ribbon, three Navy Overseas Ribbons, and a Pistol Marksmanship (Sharpshooter) Medal.

\section{Paul K. Blake, PhD}

Dr. Paul K. Blake is the Program Manager of the Nuclear Test Personnel Review (NTPR) Program, Nuclear Technologies Department, Defense Threat Reduction Agency (DTRA), Fort Belvoir, VA. DTRA safeguards America and its allies from weapons of mass destruction (chemical, biological, radiological, nuclear, and high yield explosives) by providing capabilities to reduce, eliminate, and counter the threat, and mitigate its effects. 
He leads the Department of Defense's efforts to confirm participation and reconstruct radiation doses for veterans involved in U.S. atmospheric nuclear weapons testing (1945 to 1962), and the post-World War II occupation forces of Hiroshima and Nagasaki, Japan.

Dr. Blake retired from the U. S. Navy as a captain, after serving 26 years on active duty. He served aboard the USS Fulton (AS 11) and the USS Samuel Gompers (AD 37). He served as Head, Radiation Dosimetry Division, Armed Forces Radiobiology Research Institute. Upon completing his doctoral studies in 1986, he reported to the NDC as Science Advisor. Blake had the honor of co-designing and implementing the Navy's personnel radiation dosimeter - the DT-648/PD. In 1989, he transferred to Naval Hospital Portsmouth as staff physicist and radiation safety officer and later served as Head of the Radiology Department.

In later duty assignments he served as Head, Radiological Controls Branch, on the staff of Chief of Naval Operations and as the Surgeon General's Specialty Leader for Radiation Health while assigned to the Bureau of Medicine and Surgery. In 2002, he returned to the Naval Dosimetry Center as Officer in Charge and supervised the implementation of the Navy's next generation radiation dosimeter - the DT-702/PD which currently monitors over 50,000 workers. In 2004, he briefly served on the faculty of the Uniformed Services University of Health Sciences before retiring.

Dr. Blake is a diplomate of the American Board of Health Physics and is a member of the U.S. Naval Institute and Health Physics Society. He serves as the DoD representative on the Veterans’ Advisory Board on Dose Reconstruction. He earned a bachelor's degree in chemistry and a master's degree in health physics from Rutgers, the State University of New Jersey. During his graduate studies at Rutgers University he served as a Health Physics Fellow at Brookhaven National Laboratory in Long Island, N.Y. He later earned a doctorate degree in medical physics from the University of Wisconsin-Madison.

\section{William J. Morris, MS}

Mr. Morris is a consultant living in Williamsburg, Virginia. He retired after working for the Department of the Navy for 39 and one-half years. He initially worked as a guest worker in health physics at National Bureau of Standards at the reactor and linear accelerator for six months each and a year at Naval Research Laboratory assisting in the decommissioning of the NRL.

He worked as a staff health physicist in the Naval Facilities Engineering Command, Nuclear Engineering Division reviewing NPP operating reports, conducting safety reviews, and reviewing Navy radioactive material license applications for submittal to the Nuclear Regulatory Commission. He served on the NPP inspection team in December 1974 at McMurdo Station to review plant operations and on the NPP decommissioning crew in Deep Freeze 76 (October 1975-early February 1976) conducting field surveys for soil contamination.

Mr. Morris was a staff health physicist at the Navy Radiological Affairs Support Office (RASO) reviewing and coordinating Navy radioactive material license application submittals to the Nuclear Regulatory Commission. He inspected Navy radiation safety programs, conducted installation radiation shielding reviews, taught classes to Navy Radiation Safety Officers, and conducted radiation incident and exposure investigations. 
He served as head of the RASO licensing and laboratory branch. His responsibilities included coordinating licensing, shielding reviews and laboratory services. In 1987, the Navy obtained a USNRC Master Materials License for radioactive material used by the Navy and the US Marine Corp. He was responsible for review of permit applications for industrial uses of radioactive material, recommending approval to the Navy Radiation Safety Committee, and reviewing the impact of and drafting Navy comments on proposed USNRC regulations.

He later became an environmental protection manager with RASO. His responsibilities included reviewing historical radiological site assessments, decommissioning plans and surveys, conducting special studies and coordinating issues with senior Navy and federal agency managers.

Mr. Morris is chairman of the ANSI N43 Accredited Standards Committee on Equipment for Non-Medical Radiation Applications and served on working subcommittees for two ANSI standards. He is a diplomate of the American Board of Health Physics and a member of the Health Physics Society. He earned a Bachelor's degree in chemical engineering from the University of Wisconsin and a Master's degree in nuclear engineering from Catholic University in Washington, DC.

\section{Jason D. Dunavant, MS}

Mr. Dunavant is a senior health physicist in the NTPR Program at SAIC in McLean, VA. He develops radiological dose assessments and dose reconstructions for atomic veterans to include technical analyses of historical data, reviewing radiation measurement, and producing detailed radiation dose calculations for atomic veterans. He has developed standardized methods and quality assurance procedures used for dose reconstructions. He was one of the authors of the basis document for a technical approach for expedited processing of doses for atomic veterans. In addition, he has worked on the basis document for doses of veterans who were exposed to radioactive light sources in night vision adaptometers.

He has also worked on radiation dose assessments for U.S. DoD-affiliated populations who were exposed to radioactive material released from the Fukushima Daiichi Nuclear Power Plant following the Great Pacific Tsunami in 2011. He has worked on both deterministic and probabilistic dose assessment analysis of DoD-affiliated populations in Japan.

Before coming to SAIC, he was the Director of Radiation Safety at Georgetown University Hospital. He oversaw the radiation safety program for a broad scope USNRC medical license, a District of Columbia radiation permit, and a wide range of machine-produced radiation sources. He oversaw the radiation safety aspects of medical treatment and of human-use research involving radioactive material and machine-produced radiation. He participated in a Department of Homeland Security pilot program on hospital preparation for contaminated patients and radiological incident response.

Mr. Dunavant retired from the Army after 20 years of service as a nuclear medical science officer. He served as a health physicist and radiation safety officer at the Army Environmental Hygiene Agency (now called the Army Institute for Public Health). He served as the deputy radiation safety officer at White Sands Missile Range in New Mexico; and at Walter Reed Army Medical Center and the Walter Reed Army Institute of Research in Washington, DC. He was the Chief of Health Physics at Tripler Army Medical Center in Honolulu, Hawaii. His 
last assignment in the Army was as the Radiological Health Officer and the Radiation Safety Staff Officer for Army Materiel Command at Fort Belvoir, VA where he oversaw the radiation safety programs for military items containing radioactive material and the radiation safety aspects of equipment acquisition programs.

He is a diplomate of the American Board of Health Physics and a member of the Health Physics Society and American Society of Test and Measurements. He earned a bachelor's degree in physics from the University of Houston and a master's degree in health physics from Colorado State University.

\section{Mondher Chehata, PhD}

Dr. Mondher Chehata is a senior environmental scientist and program manager for NTPR Program at SAIC in McLean, VA. He manages the SAIC program to produce radiation dose assessments for atomic veterans. His previous work in NTPR included analyzing historical records; evaluating radiation data, and producing detailed radiation dose assessment. During his time as program manager, he has developed technical methods and authored reports on using probabilistic analysis for radiation dose assessment, on expedited processing for atomic veterans, and on a variety of specific technical aspects of the NTPR program.

Dr. Chehata has also participated in dose assessments for U.S. DoD-affiliated populations who were exposed to radioactive material released from the Fukushima Daiichi Nuclear Power Plant following the 2011 Great East Japan Earthquake and Tsunami. He participated in the development of dose estimates for U.S. Service members, civilians and dependents who were deployed in Japan and those who carried out the humanitarian relief assistance to the government of Japan and affected populations. In, addition, he developed probabilistic models to assess radiation doses U.S. DoD-affiliated persons present in Japan following the nuclear reactor accident.

Prior to working on the NTPR program, Dr. Chehata's professional career of more than 25 years included supporting programs for the Office of Science and Technology, Office of Environmental Management of the Department of Energy, the Environmental Protection Agency, the National Park Service, the U.S. Army, the U.S. Agency for International Development, and other domestic and international programs. His work included, among others, hydrological and environmental modeling, GIS-based water security threat assessment, and evaluation of environmental information systems.

Dr. Chehata earned a bachelor's and master's degree in hydraulics engineering and water resources management from the University of Tunis and a doctorate degree in civil engineering from Colorado State University. 